\title{
Tumorigenic Responses of Cancer-Associated Stromal Fibroblasts after Ablative Radiotherapy: A Transcriptome-Profiling Study
}

\author{
Inigo Martinez-Zubiaurre ${ }^{1}$, Christopher G. Fenton ${ }^{1,2}$, Hagar Taman ${ }^{1,2}$, Ingvild Pettersen ${ }^{1}$, \\ Turid Hellevik ${ }^{3}$, Ruth H. Paulssen ${ }^{1,2^{*}}$ \\ ${ }^{1}$ Institute of Clinical Medicine, Troms $\varnothing$, Norway; ${ }^{2}$ Microarray Resource Centre Tromsø (MRCT), Institute of Clinical Medicine, \\ University of Tromsø, Tromsø, Norway; ${ }^{3}$ Department of Oncology, University Hospital of North-Norway, Tromsø, Norway. \\ Email: *ruth.h.paulssen@uit.no
}

Received November $7^{\text {th }}, 2012$; revised December $11^{\text {th }}, 2012$; accepted December $19^{\text {th }}, 2012$

\begin{abstract}
Cancer-associated fibroblasts (CAFs) are key elements in the progression of cancer and thereby represent important targets for cancer therapies. Increased attention has been given to ablative radiotherapy in the clinics. Therefore, in this study we have aimed at identifying the transcriptional responses occurring in primary CAFs exposed to high-dose irradiation. Established primary CAFs obtained from non-small-cell lung cancer (NSCLC) patient material were irradiated with a single dose of $18 \mathrm{~Gy}$ and total RNA was isolated $24 \mathrm{hrs}$ after treatment. Radiation-induced transcriptional alterations were investigated by gene expression analysis using genome-wide microarrays. Obtained results were verified by qRT-PCR of relevant genes. Confirmation of gene expression outcomes was achieved by diverse functional and expression assays including DNA damage response, measurements of reactive oxygen species (ROS) by flow cytometry and senescence-associated $\beta$-galactosidase. Irradiation resulted in differential expression of 680 genes of which 557 were up- and 127 down-regulated. Of those, 153 genes were differentially expressed with a fold-change greater than 1.0 and an adjusted p-value less than 0.05 across different comparisons (non-irradiated vs. irradiated). Expression patterns revealed profound changes in biological functions and processes involved in DNA repair, apoptosis, p53 pathway, autophagy, senescence, ROS production and immune response. CAFs display pro- and anti-tumorigenic effects after having received a single high-dose radiation. The measured effects will have an impact on the tumor microenvironment in respect to tumor growth and metastasis.
\end{abstract}

Keywords: Stereotactic Ablative Radiotherapy (SART); Gene Expression; Cancer-Associated Fibroblasts (CAFs)

\section{Introduction}

Hypofractionated radiotherapy is emerging as a new treatment option for solid neoplasms of different kinds, including but not limited to medically inoperable stage I non-smal-cell lung cancers (NSCLC) [1,2]. Advances in radiotherapy (RT)-technology thus now permit accurate delivery of high-dose (or ablative) RT to target earlystage small tumors with acceptable toxicity to the surrounding normal tissue [3]. Clinical outcomes indicate that ablative RT is associated with improved local control and overall survival compared with conventional RT regimens $[2,4]$. Despite the encouraging clinical outcomes presented in recent years, little attention has been paid to the biological reactions associated to ablative doses of radiation to tumors.

Tumor progression is a multi-step process orchestrated

"Corresponding author. by many different cell associated to the malign tissue, such as cancer-associated fibroblasts (CAFs), pericytes, lymphocytes, endothelial cells, extracelluar matrix and myeloid cells [5-7]. CAFs are frequently found in the reactive stroma of cancers, and their presence in large number is associated with poor prognosis. When acting on cancer cells, CAFs promote tumor growth and invasion, and enhance angiogenesis by secreting factors that activate endothelial cells and pericytes. Through the secretion of cytokines, CAFs and immune cells can exert both, tumor-suppressing and tumor-promoting effects [8].

Exposure of normal fibroblasts to ionizing radiation has been a common model to study cellular responses to genotoxic stress $[9,10]$. Aiming for a better understanding of the collateral effects induced by ionizing radiation on normal tissue, some studies have tried to decode the overall changes in gene expression on normal fibroblasts by applying microarray gene technology [9-13]. After 
functional categorization of differentially expressed genes, some common traits on altered pathways can be denoted from those studies including DNA damage responses, regulation of cell cycle and proliferation, programmed cell death, p53 target genes, signaling pathways, ROS scavenging and ECM remodeling. Despite the available knowledge on normal tissue fibroblast responses to RT, few reports have focused on the effects of RT on intratumoral reactive stromal fibroblast (CAFs). In a recent study from our laboratory we show that CAF survive to relative high single radiation doses, however the cellular phenotype becomes profoundly altered, characterized by the induction of permanent DNA damage responses and the acquisition of a senescent phenoltype and growth arrest [14]. Of note, in that study we show that the expression of some matrix metalloproteinases becomes altered along with overexpression of cell surface integrins.

This work is intended to complement our initial study on radiation-induced responses by tumor-associated fibroblast. Following the rational of using single high radiation doses to reproduce the effects provoked by sterotactic ablative radiation therapy regimens, in this study we perform transcriptional profiling to rule out in which degree CAFs become pro-tumorigenic and/or anti-tumorigenic after irradiation. To our knowledge this is the first time that such a study has been conducted with freshly prepared CAFs.

\section{Materials and Methods}

\subsection{Human Material, Cell Isolation and CAFs Cultures}

Human CAFs were harvested from freshly resected nonsmall lung cell carcinoma (NSCLC) tumor tissues. Tumors from eight patients with an average age of 58 years (range 44 - 71) were included in this study. The Regional Ethical Committee (REK-Nord) approved the study, and all patients provided written informed consent. Fibroblasts from tumors were isolated and characterized following standard procedures. Briefly, tumor resections were collected and cut into $1-1.5 \mathrm{~mm}^{3}$ pieces. Enzymatic digestion of tissues was carried out for $1.5 \mathrm{hrs}$ in 10 mL DMEM/HAM'S F-12 containing bacterial collagenase (Cat.\#C-9407, Sigma-Aldrich, St. Louis, MO, USA) at a final concentration of $0.8 \mathrm{mg} / \mathrm{mL}$. Digested tissue was spun down to eliminate collagenase, and resuspended in fresh growth medium (DMEM/HAM'S F-12 supplemented with $10 \%$ FBS). Pure fibroblast cultures were obtained by selective cell detachment from the primary culture mix used $2 \mathrm{mM}$ PBS-EDTA solution, and by further cell propagation in the presence of $10 \%$ FBS. Cells were used for experiments after the second passage ( 2 - 3 weeks). The resulting cultures were characterized for purity and cell identity by flow cytometry using a FITC-conjugated anti-human $\alpha$-SMA (smooth muscle $\alpha$-actin) antibody (Abcam; Cat.\#ab8211) (data not shown), and by immuno-fluorescent staining with anti-FAP (fibroblast activation protein) antibody (Abcam; Cat.\#ab53066) on formalin-fixed CAF cultures.

\subsection{Irradiation of Cells}

Radiation protocols were established after initial doseescalating pilot trials. Hence, adherent CAFs cultured in flasks were irradiated at RT with high energy photons produced by a Varian clinical linear-accelerator, delivered as single doses of 2, 6, 12 and 18 Gy. Standard parameters for dose delivery was depth $30 \mathrm{~mm}$, beam quality $15 \mathrm{MV}$, dose-rate $6 \mathrm{~Gy} / \mathrm{min}$ and field size $20 \times 20 \mathrm{~cm}$. Radiation-doses were confirmed to be correct within an acceptable $\pm 4 \%$ by Thermo-Luminescent Dosimeters (TLDs) [15]. Cell survival/death after radiation was assessed by light microscopy during the initial three weeks, by automated cell index analyses (xCelligence, Roche) and by MTT cell proliferation and viability assays [16] at different time points [14]. The extent of radiation-induced apoptosis and necrosis in CAFs was determined by staining for annexin $\mathrm{V}$ and propidium iodide respectively (data not shown).

\subsection{DNA Damage Response (DDR) Foci Staining}

CAFs were cultured in 2-well chamber slides (Nunc, Thermo Fisher Scientific, NY, USA), fixed with 4\% PFA in PBS for $10 \mathrm{~min}$ at RT and permeabilized with $0.2 \%$ Triton in PBS for 8 min. Slides were then exposed to blocking buffer containing 2\% HSA in PBS, for $30 \mathrm{~min}$ at RT. Primary antibody (Rabbit anti human 53BP1; Cat. \#ab36823, Abcam, Cambridge, UK) was diluted in blocking buffer and incubated with CAFs for $45 \mathrm{~min}$ at RT. After washing with PBS, cells were incubated with secondary antibody (anti rabbit-Alexa546, Cat.\#A11010, Molecular Probes/Invitrogen, Leiden, The Netherlands) in blocking buffer, $30 \mathrm{~min}$ at RT. A second wash was followed by preparation of slides in DAPI-FluoromountG (Cat.\#0100-20, Southern Biotech, Birmingham, AL, USA). Specimens were examined in a fluorescence microscope (Zeiss Axiophot, Germany) equipped with a Nikon DS-5MC digital camera, and images were processed with Adobe ${ }^{\circledR}$ Photoshop Software (CS5).

\subsection{Senescence Associated $\beta$-Galactosidase Assays}

CAFs were seeded at a density of 20,000 cells per well in 
uncoated 6-well plates and left for attachment for $24 \mathrm{hrs}$. Adherent cells were irradiated with a single fraction of 18 Gy. Five days post-irradiation, cultures were washed twice in PBS, and fixed for 5 min at RT with freshly prepared paraformaldehyde $(2 \%)$. $\beta$-galactosidase (5bromo-4chloro-3-indolyl-B-D-galactopyranoside) staining was achieved following instructions from the manufacturer with the "Senescence Cells Histochemical Staining Kit" (Cat.no CS0030, Sigma-Aldrich, St. Louise, MO, USA). The number of $\beta$-galactosidase active and sensecent cells was determined by counting blue cells under a Nikon Eclipse TS100 model light microscope, and randomly selected fields were photographed at $1000 \times$ magnification, using an Idea SPOT digital camera.

\subsection{ROS Measurements}

Intracellular ROS was determined using the CMH2DCFDA probe (Molecular Probes, Invitrogen, Carlsbad, CA, USA) and flow cytometry. When oxidized, this probe can be detected by fluorescence with excitation at $485 \mathrm{~nm}$ and emission at $515 \mathrm{~nm}$. Irradiated CAFs were seeded in 6 well cell culture plates $\left(1 \times 10^{5}\right)$ with $2 \mathrm{ml}$ of complete growth medium and incubated overnight at $37^{\circ} \mathrm{C}, 5 \% \mathrm{CO}_{2}$. The next day, the cells were washed 2 times with Hanks Balanced Salt Solution with $\mathrm{CaCl}_{2}$ and $\mathrm{MgCl}_{2}$ (HBSS) (GIBCO, Invitrogen, Carlsbad, CA) and incubated for $30 \mathrm{~min}$ with $2.5 \mu \mathrm{M}$ CM-H2DCFDA in HBSS. Subsequently the cells were trypsinized, resuspended in $0.5 \mathrm{ml}$ HBSS and immediately analysed by flow cytometry (FACSAria, BD Biosciences). Ten thousand events were collected and analyzed by BD FACSDiva Version 5.0.2. The numbers presented are the median values of the fluorescent intensity.

\subsection{RNA Preparation and Quality/Quantity Control}

Disruption and homogenization of cells were performed in lysis buffer using the MagNa Lyser Instrument (Roche Applied Science, Germany) and according to the manufacturer's protocol. Subsequently, total RNA was isolated with the MagNa Pure Compact Instrument and the MagNa Pure Compact RNA Isolation Kit (Roche Applied Science, Germany) as previously described [17]. RNA was quantified by measuring absorbance at $260 \mathrm{~nm}$, and RNA purity was determined by the ratios OD260 $\mathrm{nm} / 280 \mathrm{~nm}$ and OD230/280 $\mathrm{nm}$ using the NanoDrop instrument (NanoDrop ${ }^{\circledR}$ ND-1000, Wilmington, USA). The RNA integrity was determined by electrophoresis using the BioRad Experion Bioanalyzer (Data not shown). All the RNA preparations were verified for possible genomic DNA contamination by a minus-RT-PCR conducted directly on RNA samples, with human ge- nomic DNA as a positive control and amplification of the human housekeeping gene cyclophilin A. Genomic DNA was not detected in RNA preparations (Data not shown).

\subsection{Probe Generation and Array Hybridization}

Prior to probe generation $1 \mu \mathrm{g}$ total RNA was amplified with the Ambion ${ }^{\circledR}$ MessageAmp ${ }^{\text {TM }}$ II aRNA Amplification Kit (Applied Biosystems Inc., USA). RNA samples were transcribed to cDNA using the Invitrogen superscript cDNA synthesis kit (Invitrogen ${ }^{\mathrm{TM}}$, USA). cDNA and Cy3-labelled with the NimbleGen One-Color DNA Labeling Kit and according to the manufacturer's protocol (Roche NimbleGen, Germany). Labelled probes were hybridized to a NimbleGen oligo arrays $(12 \times 135 \mathrm{~K})$ with the Roche NimbleGen hybridization system for 16 hours at $42^{\circ} \mathrm{C}$. The microarray slides were washed according to the manufacturer's protocol and scanned with an Axon GenePix 4000B scanner (Molecular Devices Inc., USA). Features were extracted by using the NimbleScan v2.5 software.

\subsection{Data Analysis and Statistical Analysis}

Normalization was carried out using quantile normalization [18]. For the purpose of finding differentially expressed genes, we applied an empirical Bayes analysis using the LIMMA package [19], and significance was determined at the 0.05 level corrected for false discovery rate (FDR) using the Benjamini-Hochberg method [20]. Principal component analysis (PCA) was carried out on the data in order to visualize the data structure and look for potential outlier samples [21]. The differentially expressed genes were annotated by Protein Analysis THrough Evolutionary Relationships (PANTHER; http://www.panther.org/). Gene SetEnrichment Analysis (GSEA) was performed using the $\mathrm{R}$ statistical package (http://www.broad.mit.edu/gsea/). The microarray data were prepared according to minimum information about a microarray experiment (MIAME) recommendations and deposited in the Gene Expression Omnibus (GEO) database: http://www.ncbi.nlm.nih.gov/geo/. The GEO accession number for the series is GSE37318.

\subsection{Validation of Gene Expression by Quantitative Real-Time Polymerase Chain Reaction}

Total RNA was prepared representative for four irradiated and non-treated CAF samples each. These were reverse transcribed using Transcriptor First Strand cDNA synthesis Kit (Roche Applied Science, Germany) as described in the manufacturer's protocol. TaqMan real-time 
PCR amplification was performed with an ABI HT7900 Instrument (Applied Biosystems) using primers and probes designed with the Universal Probe Library (Roche Applied Science, Germany) and Taqman ${ }^{\mathbb{B}}$ Gene Expression Assays (Applied Biosystems). The following primers and probes and inventory assays have been used: MMP11-fw, 5'-GGTGCCCTCTGAGATCGAC-3', MMP 11-rev, 5'-TTCACAGGGTCAAACTTCCAG-3', MMP11 probe \#4; ATG16L2-fw,

5'-GGCCACAATGACCAGAAGAT-3', AGT16L2-rev, 5'-GGATGACCTGGGTGCAGT-3', AGT16L2 probe \#56; COL7A1-fw, 5'-GCTGGTGCTGCCTTTCTC-3', COL7A1-rev, 5'-TCCAGGCCGAACTCTGTC-3', COL7A1 probe \#71; IL12A-fw,

5'-CACTCCCAAAACCTGCTGAG-3', IL12A-rev,

5'-TCTCTTCAGAAGGTGCAAGGGTA-3', IL12A

probe \#50; GDF15-fw,

5'-CGGATACTCACGCCAGAAGT-3', GDF15-rev,

5'-AGAGATACGCAGGTGCAGGT, GDF15 pobe \# 28; 5'PPIA-fw, 5'-TGCTGGACCCAACACAAAT-3',

PPIA-rev, 5'-CACATGCTTGCCATCCAA-3', PPIA (cyclophilin) probe \#48, CYP3A7, Hs00426361_m1; TP53I3, Hs00936520 m1; MDM2, Hs1066930:m1; FDXR, Hs01031618_g1. Samples of each experiment were run in triplicate and averaged for final quantification. The fold-changes were calculated as described previously by analysis of relative gene expression data using real-time quantitative PCR and the $2(-\Delta \Delta(\mathrm{T}))$ method [22].

\section{Results}

\subsection{Survival Rates and CAFs Responses to Ablative Radiation Doses}

All the data generated in this study come from cell cultures directly prepared from lung tumor specimens obtained from 8 different donors after surgical resection (Figure 1). In a previous study from our group we describe in detail the isolation and characterization of the tumor fibroblast cultures that have been used also for this study [14].

Of note, flow cytometry analyses using the fibroblast specific marker $\alpha$-SMA reveal a purity above $99.5 \%$, which gives full credibility to the data generated with this material. The intrinsic radioresistance of CAFs in dose escalating trial experiments have also been evaluated and described by us previously [14]. A single dose of 18 Gy happens to be sub-lethal for CAFs, however we have observed that single doses above 12 Gy induce enduring DNA damage responses (nuclear foci of 53BP1) and the cells enter into a permanent cell growth arrest or sensecence. Hence, based on our previous experience we have chosen the use of a single dose of $18 \mathrm{~Gy}$ as the basis
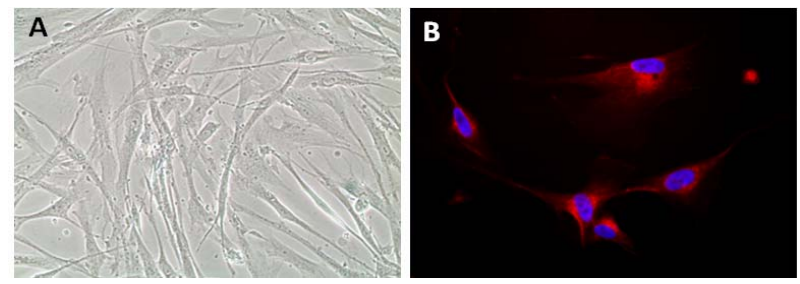

Figure 1. A 200× magnification phase contrast micrograph of three weeks old CAFs in monolayer culture is shown in (A). CAFs are characterized by immunostaining with antiFAP (fibroblast activating protein), a specific marker of reactive fibroblasts $(400 \times$ magnification) and as shown in (B).

protocol for conducting this study. In previous studies done by others on normal fibroblasts, 24 hours post-irradiation seems to be the time point where the largest number of genes is altered [10]. We have therefore set up 24 hours as the single and most relevant time point to analyse changes in gene expression.

\subsection{Radiation-Induced Gene Expression}

Large scale molecular responses in CAFs obtained from NSLC patient material to ablative doses of radiation were studied by measuring genome-wide transcript-level changes using human genome survey microarrays as described in Materials and Methods. After pre-processing and normalization, a total of 680 differentially expressed were found in the group of irradiated CAF samples, of which 127 genes were down- and 553 were up-regulated transcripts with $p<0.05$ (Supplemental list 1). Of all differentially expressed genes, 601 could be annotated by $\mathrm{GO}$ terms for biological processes in Kegg

(http://www.genome.jp/kegg/) and are summarized in Supplemental list 2. Principal component analysis (PCA) revealed that the major variability in the data set is caused by the difference between irradiated and non-irradiated CAFs (Data not shown). The number and distribution of 153 differentially expressed genes with fold change greater than 1 and an adjusted p-value less than 0.05 across different comparisons is shown in Figure 2.

\subsection{Radiation-Induced Pathways after Functional Categorization}

Candidate genes which relate to senescence have been extracted from the GenAge database

(http://genomics.senescence.info/genes/human.html)

(Table 1). In addition, the expression levels of some differentially expressed genes found in this study have been verified by qRT-PCR (Table 2).

Differentially expressed genes were annotated with PANTHER (http://www.pantherdb.org/) to different biological processes: cell cycle regulation and DNA repair 


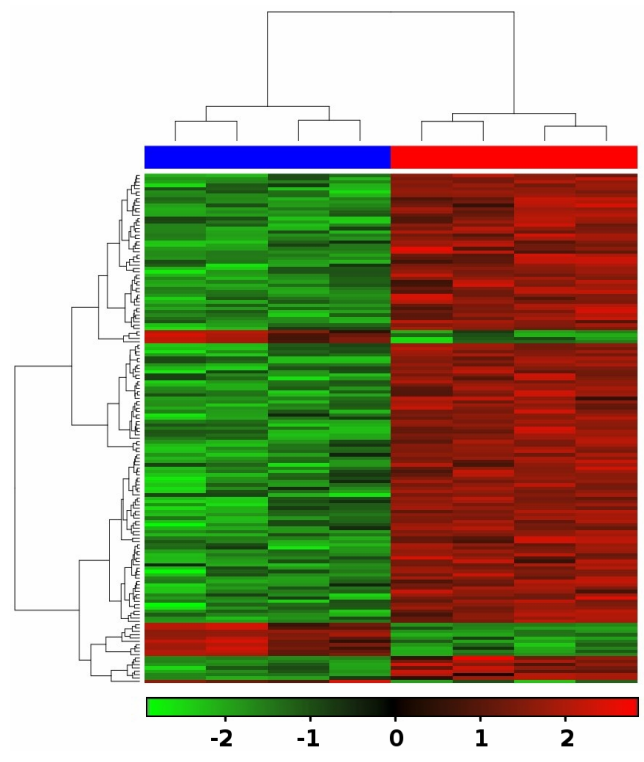

Figure 2. Heatmap of 153 differentially expressed genes in irradiated CAFs with fold change greater than 1.0 and an adjusted p-value less than 0.05 are shown. CAF samples are shown as red bar (top) and non-irradiated CAF samples as blue bar (top). Legend (bottom) shows the fold change [ $\log _{2}$ (radiated) $-\log _{2}$ (normal)] color coded values in the heatmap.
(Table 3), oxidative stress (Table 4), apoptosis (Table 5), autophagy (Table 6), and cell communication/cell adhesion (Table 7).

Increased expression levels of interleukin 12 (IL-12), autophagy related protein 16-2 (ATG16L2), growth differentiation factor 15 (GDF15), cytochrome P450, family 3, subfamily A, polypeptide 7 (CYP3A7), NADH adenodoxin osireductase (FDXR), transformed $3 \mathrm{t} 3$ cell double minute 2 (MDM2), collagen type 7 alpha 1 (COL7A1) and stromelysin 3 (MMP11), and tumor protein p53 inducible protein 3 (TP53IP3) were confirmed by qRTPCR (Table 2). Figure 3 depicts differential expression of 37 selected genes that are discussed in more detail below.

\subsection{Validation of Expression Data by Functional Assays}

Gene expression analysis indicated that some p53-dependent pathways and the cell cycle regulation machinery were altered after IR. One end point of such disturbances is the development of stress-induced cellular senescence. In our previous study we have performed quantitative and qualitative measurements of senescence on CAFs after exposure to either high single dose or fractionated

Table 1. Differentially expressed genes related to ageing/senescence in irradiated CAFs.

\begin{tabular}{|c|c|c|c|}
\hline HGNC Symbol & Common name & Biological process & $\mathrm{FC}^{*}$ \\
\hline APTX & aprataxin & stress response & +1.3 \\
\hline BAX & BCL2-associated X protein & apoptosis & +1.7 \\
\hline BLM & Bloom syndrome, RecQ helicase-like & mitosis & -5.2 \\
\hline HMGB1 & high-motility group box 1 & stress response & -1.6 \\
\hline HRAS & v-Ha-ras Harvey rat sarcoma Viral oncogene homolog & apoptosis, cell cyle, growth \& development & +1.9 \\
\hline HSF 1 & heat shock transcription factor 1 & stress response & +1.5 \\
\hline HSPA8 & heat shock $70 \mathrm{kDa}$ protein 8 & stress response & -1.2 \\
\hline MDM2 & Mdm2 p53 binding protein homolog & cell cycle, apoptosis & +3.0 \\
\hline NRG1 & neuregulin 1 & apoptosis, growth \& development & +6.9 \\
\hline PARP1 & poly (ADP-ribose) polymerase 1 & apoptosis & -1.2 \\
\hline PCNA & proliferating cell nuclear antigen & cell cycle & +3.3 \\
\hline PIN1 & peptidylpropyl cis/trans isomerase 1 & Apoptosis cell cycle & +1.4 \\
\hline PML & promyelocytic leukemia cell cycle & apoptosis, & +1.4 \\
\hline PPM1D & protein phosphatase $1 \mathrm{D}$ cell cycle & stress response, & +1.6 \\
\hline PTPN11 & protein tyrosine phosphatase, non-receptor type 11 & growth \& development & -1.3 \\
\hline $\mathrm{RCF} 4$ & replication factor $\mathrm{C} 4$ & unclassified & -1.7 \\
\hline SUMO1 & SMT3 supressor of mif two 3 homplog 1 & apoptosis & -1.2 \\
\hline STE24 & zinc metallopeptidase & unclassified & -1.5 \\
\hline
\end{tabular}

${ }^{*}$ Values are shown as fold-change representing eight independent microarray experiments. 
Table 2. Verification of selected expressed genes in irradiated CAFs by qPCR.

\begin{tabular}{|c|c|c|c|}
\hline Gene Symbol & Gene name & $\mathrm{FC}^{*}$ & $\mathrm{qPCR}^{\#}$ \\
\hline ATG16L2 & autophagy related protein $16-2$ & +1.89 & $+1.46 \pm 0.296$ \\
\hline COL7A1 & collagen type 7 alpha 1 & +3.04 & $+10.50 \pm 0.333$ \\
\hline CYP3A7 & cytochrome P450, family 3 , subfamily A,polypeptide 7 & +3.20 & $+3.30 \pm 0.078$ \\
\hline FDXR & $\mathrm{NADH}$ adrenodoxin oxireductase & +3.90 & $+5.22 \pm 0.319$ \\
\hline GDF15 & growth differentiation factor 15 & +3.80 & $+2.14 \pm 0.008$ \\
\hline IL12A & interleukin $12 \mathrm{~A}$ & +2.23 & $+2.13 \pm 0.001$ \\
\hline MMP11 & stromelysin-3 & +2.42 & $+1.93 \pm 0.310$ \\
\hline MDM2 & transformed $3 \mathrm{t} 3$ cell double minute 2 & +2.36 & $+3.32 \pm 0.224$ \\
\hline TP53I3 & tumor protein $\mathrm{p} 53$ inducible protein 3 & +2.12 & $+1.76 \pm 0.361$ \\
\hline
\end{tabular}

${ }^{*}$ Values are shown as fold-change (FC) representing eight independent microarray experiments and ${ }^{\#}$ RT-PCR validations in triplicate \pm S.D. of each representative RNA sample.

Table 3. Differentially expressed genes $(\mathbf{p}<\mathbf{0 . 0 5})$ related to cell cycle regulation and DNA repair in irradiated CAFs.

\begin{tabular}{|c|c|c|}
\hline HGNC Symbol & Common name & $\mathrm{FC}^{*}$ \\
\hline ANAPC2 & anaphase promoting complex subunit 2 & +2.0 \\
\hline ANAPC11 & anaphase promoting complex subunit 11 & +1.5 \\
\hline APTX & aprataxin & +1.3 \\
\hline ASCC3 & activating signal cointegrator 1 complex subunit 3 & +1.7 \\
\hline BLM & Bloom syndrome protein & -5.2 \\
\hline CEP164 & centrosomal protein $164 \mathrm{kDa}$ & +1.7 \\
\hline CCNE2 & cyclin E2 & +4.4 \\
\hline CCNG1 & cyclin G1 & +1.2 \\
\hline CCNK & cyclin $\mathrm{K}$ & +1.2 \\
\hline CCNL2 & cyclin L2 & +1.5 \\
\hline CDC6 & cell division cycle, 6 homolog & -3.2 \\
\hline $\mathrm{CDC} 34$ & cell division cycle, 34 homolog & +1.4 \\
\hline DDB2 & damage-specific DNA binding protein 2 & +2.6 \\
\hline DNASE1 & deoxyribonuclease 1 & +1.4 \\
\hline DTL & denticleless homolog & -5.0 \\
\hline $\mathrm{H} 2 \mathrm{BFS}$ & $\mathrm{H} 2 \mathrm{~B}$ histone family, member $\mathrm{S}$ & +1.7 \\
\hline HIST1H2AC & histone cluster $1, \mathrm{H} 2 \mathrm{ac}$ & +1.9 \\
\hline HIST1H2BE & histone cluster $1, \mathrm{H} 2 \mathrm{be}$ & +1.6 \\
\hline HIST1H2BF & histone cluster $1, \mathrm{H} 2 \mathrm{bf}$ & +2.4 \\
\hline HIST1H2BK & histone cluster $1, \mathrm{H} 2 \mathrm{bk}$ & +2.5 \\
\hline HIST1H2BO & histone cluster $1, \mathrm{H} 2$ bo & +1.6 \\
\hline LIG1 & DNA ligase 1 & +2.4 \\
\hline LZTR1 & leucine zipper-like transcritional regulator 1 & +1.4 \\
\hline MCM10 & minichromosome maintenance complex component 10 & -8.3 \\
\hline MKNK1 & MAP kinase-interacting serine/threonine-protein kinase 1 & +1.4 \\
\hline MNS1 & meiosis-specific nuclear structural protein 1 & -2.3 \\
\hline MSH2 & DNA mismatch repair protein Msh2 & -1.5 \\
\hline PCNA & proliferating cell nuclear antigen & +3.3 \\
\hline PFTK1 & serine/threonine protein kinase PFTAIRE-1 & -1.5 \\
\hline PIN1 & peptidylprolyl cis/trans isomerase, NIMA-interacting 1 & +1.4 \\
\hline POLL & DNA polymerase lambda & +1.5 \\
\hline PTPRU & receptor-type tyrosine-protein phosphatase $U$ & +1.8 \\
\hline PRKX & serine/threonine protein kinase & +1.5 \\
\hline RAGE & MAPK/MAK/MRK overlapping kinase & +1.6 \\
\hline RBL2 & retinoblastome-like protein 2 & -1.6 \\
\hline RFC4 & replication factor $\mathrm{C}$ subunit 4 & -1.7 \\
\hline RPA4 & replication protein $\mathrm{A} 4$ & +1.8 \\
\hline SMG6 & telomerase-binding protein EST1A & +1.4 \\
\hline TRIM28 & transcrition intermediary factor 1-beta & +1.4 \\
\hline $\mathrm{XPC}$ & xeroderma pigmentosum, complementation group & +1.8 \\
\hline
\end{tabular}

${ }^{*}$ Values are shown as fold-change (FC) representing eight independent microarray experiments. 
Table 4. Differentially expressed genes $(p<0.05)$ related to oxidative stress in irradiated CAFs.

\begin{tabular}{lll}
\hline HGNC Symbol & Common name & FC $^{*}$ \\
\hline ACAD10 & acyl-CoA dehudrogenase family member 10 & +1.3 \\
ACO2 & aconitate hydratase, mitochondrial & +1.5 \\
AMT & aminomethyl transferase, mitochondrial & +1.5 \\
BCS1L & mitochondrial chaperone BCS1 & +1.5 \\
CYC1 & cytochrome c1, heme protein, mitochondrial & -1.3 \\
CYP3A4 & cytochrome P450, family 3, subfamily A, polypeptide 4 & +3.2 \\
CYP3A7 & cytochrome P450, family 3, subfamily A, polypeptide 7 \\
DECR1 & peroxisomal 2, 4-dienoyl-CoA reductase & +3.2 \\
FDXR & NADH adrenodoxin oxireductase & +1.9 \\
FOXRED1 & FAD-dependent oxireductase domain-containing protein 1 & +4.1 \\
GFER & FAD-linked sulfhydryloxidase ALR & +1.9 \\
GGT1 & gamma-glutamyltransferase 1 & +1.6 \\
IDH3B & isocitrate dehydrogenease [49] subunitbeta, mitochondrial & +2.5 \\
NDUFA2 & NADH dehydrogenase (ubiquinone) 1 alpha subcomplex, 2 & +1.4 \\
NDUFA12 & NADH dehydrogenase (ubiquinone) 1 alpha subcomplex, 12 & +1.6 \\
NDUFA13 & NADH dehydrogenase (ubiquinone) 1 alpha subcomplex, 13 \\
NDUFC1 & NADH dehydrogenase (ubiquinone) 1, subcomplex unknown & +1.2 \\
PTGES2 & prostaglandin E synthase 2 truncated form \\
SESN1 & sestrin-1 & +1.5 \\
SESN3 & sestrin 3 & +1.8 \\
TP5313 & tumor protein p53 inducible protein 3 \\
UCRC & cytochrome b-c1 complex subunit 9 & +1.3 \\
\hline
\end{tabular}

*Values are shown as fold-change (FC) representing eight independent microarray experiments.

Table 5. Differentially expressed genes $(p<0.05)$ related to apoptosis in irradiated CAFs.

\begin{tabular}{|c|c|c|}
\hline HGNC Symbol & Common name & $\mathrm{FC}^{*}$ \\
\hline \multicolumn{3}{|l|}{ Anti-apoptotic } \\
\hline BAG3 & BCL2-associated athanogene 3 & +4.4 \\
\hline $\mathrm{BEX} 2$ & brain expressed X-linked 2 & +1.9 \\
\hline SYVN1 & synovial apoptosis inhibitor 1 , synoviolin & +1.5 \\
\hline TRIAP & TP53 regulated inhibitor of apoptosis 1 & +1.9 \\
\hline \multicolumn{3}{|l|}{ Pro-apoptotic } \\
\hline CRADD & CASP2 and RIPK1 domain containing adaptor with death domain & +1.6 \\
\hline LRDD & leucine-rich repeats and death domain containing & +4.1 \\
\hline NALP1 & death effector filament-forming ced-4-like apoptosis protein & +1.8 \\
\hline PYCARD & caspase recruitment domain-containing protein 5 & +1.4 \\
\hline \multicolumn{3}{|l|}{ Other apoptotic } \\
\hline ASAH3L & alkaline ceramidase 2 & +2.9 \\
\hline BAG5 & Bag family molecular chaperone regulator 5 & -1.3 \\
\hline $\mathrm{BAX}$ & BCL2-associated X protein & +1.7 \\
\hline BLNK & B-cell linker protein & +6.5 \\
\hline CYFIP2 & cytoplasmic FMR1-interacting protein 2 & +9.0 \\
\hline GSK3A & glycogen synthase kinase 3 alpha & +1.3 \\
\hline MDM2 & Mdm2 p53 binding protein homolog & +2.3 \\
\hline SGK2 & serine/threonine protein kinase Sgk2 & -2.6 \\
\hline TIGAR & TP53-induced glycolysis and apoptosis regulator & +2.2 \\
\hline TP53I3 & tumor protein p53 inducible protein 3 & +2.1 \\
\hline
\end{tabular}

${ }^{*}$ Values are shown as fold-change (FC) representing eight independent microarray experiments. 
Table 6. Differentially expressed genes $(\mathrm{p}<0.05)$ related to autophagy in irradiated CAFs.

\begin{tabular}{lll}
\hline HGNC Symbol & Common name & \\
\hline AP1B1 & adaptor-related protein complex 1, beta 1 subunit \\
AP3B2 & adaptor-related protein complex 3, beta 2 subunit & +1.7 \\
ATG4D & ATG4 autophagy related 4, homolog D & +2.9 \\
ATG16L2 & ATG16 autophagy related 16-like 2 & +1.4 \\
AP1G2 & adaptor-related protein complex 1, gamma 2 subunit & +1.9 \\
AP1S1 & adaptor-related protein complex 1, sigma 1 subunit \\
CLCA2 & chloride channel accessory 2 \\
CLTB & clathrin & +1.6 \\
HMGB1 & high-mobility group box 1 \\
\hline
\end{tabular}

*Values are shown as fold-change (FC) representing eight independent microarray experiments.

Table 7. Differentially expressed genes $(p<0.05)$ related to cell communication/cell adhesion and other biological processes in irradiated CAFs.

\begin{tabular}{|c|c|c|}
\hline HGNC Symbol & Common name & $\mathrm{FC}^{*}$ \\
\hline ADAM9 & ADAM metallopeptidase domain 9 & -1.5 \\
\hline AGRN & agrin & +1.5 \\
\hline ANGPT1 & angiopoietin 1 & -1.4 \\
\hline AREG & amphiregulin & +2.7 \\
\hline ARFGAP1 & ADP-ribosylation factor GTPase-activating protein 1 & +1.4 \\
\hline ARHGAP30 & Rho GTPase-activating protein 30 & +1.9 \\
\hline BAIAP2 & brain-specific angiogenesis inhibitor 1 -associated protein 2 & +1.3 \\
\hline CLCA2 & chloride channel accessory 2 & +4.0 \\
\hline COL7A1 & collagen, type VII, alpha & +3.0 \\
\hline CSF1 & colony-stimulating factor 1 & +1.7 \\
\hline DUSP6 & dual specificity protein phophatase 6 & +1.5 \\
\hline DYNC1H1 & cytoplasmic dynein 1 heavy chain 1 & +1.5 \\
\hline EPS8L2 & Epidermal growth factor receptor pathway substrate 8 -related protein 2 & +2.2 \\
\hline GDNF & glial cell line-derived neurotrophic factor & +3.4 \\
\hline GPC1 & glypican 1 & +1.9 \\
\hline GPC6 & glypican 6 & -1.5 \\
\hline HYAL3 & hyaluronidase 3 & +2.5 \\
\hline IL12A & interleukin $12 \mathrm{~A}$ & +3.1 \\
\hline IL1F10 & interleukin 1 family, member 10 (theta) & +1.3 \\
\hline KIF1C & kinesin-like protein $1 \mathrm{C}$ & +1.8 \\
\hline KIF7 & kinesin-like protein $\mathrm{F} 7$ & +1.3 \\
\hline MGP & matrix Gla protein & -1.7 \\
\hline MIB2E3 & ubiquitin-protein ligase MIB2 & +2.0 \\
\hline MMP11 & matrix metallopeptidase 11 (stromelysin 3) & +2.4 \\
\hline NINJ1 & ninjurin 1 & +1.9 \\
\hline NRG1 & neuregulin 1 & +5.7 \\
\hline PIK4CA & phosphatidylinositol 4 kinase, alpha & +1.5 \\
\hline PLCD1 & phospholipase $\mathrm{C}$, delta 1 & +1.9 \\
\hline PLEKHH3 & plekstrin homology domain-containing family $\mathrm{H}$ member 3 & +2.0 \\
\hline PLK3 & polo-like kinase 3 & +2.0 \\
\hline PLXNA4B & plexin A4 & -1.9 \\
\hline PLXNB1 & plexin B1 & +2.1 \\
\hline PLXNB3 & plexin B3 & +3.4 \\
\hline PPM1D & protein phophatase 1D & +1.6 \\
\hline PPP2R5C & protein phosphatase 2 , regulatory subunit $\mathrm{B}$, gamma & -1.4 \\
\hline PROCR & endothelial protein $\mathrm{C}$ receptor & +2.0 \\
\hline RAP2B & ras-related protein rap- $2 \mathrm{~b}$ & +1.8 \\
\hline RBP2 & retinol-binding protein 2 & +2.0 \\
\hline S100A1 & S100 calcium binding protein A1 & +1.6 \\
\hline SEPT10 & septin 10 & -1.3 \\
\hline SETD7 & SET domain containing (lysine methyltransferase) 7 & -1.2 \\
\hline SFN & stratifin & +2.2 \\
\hline SHC4 & SHC-transforming protein 4 & +3.6 \\
\hline STXBP2 & syntaxin-binding protein 2 & +1.8 \\
\hline SYMPK & symplekin & +1.3 \\
\hline THSD1 & thrombospondin, type I, domain containing 1 & +2.6 \\
\hline TUPGCP3 & gamma-tubulin complex component 3 & -1.3 \\
\hline TUPGCP6 & gamma-tubulin complex component 6 & +1.7 \\
\hline VWCE & von Willebrand factor and EGF domain-containing protein & +8.7 \\
\hline
\end{tabular}

${ }^{*}$ Values are shown as fold-change (FC) representing eight independent microarray experiments. 

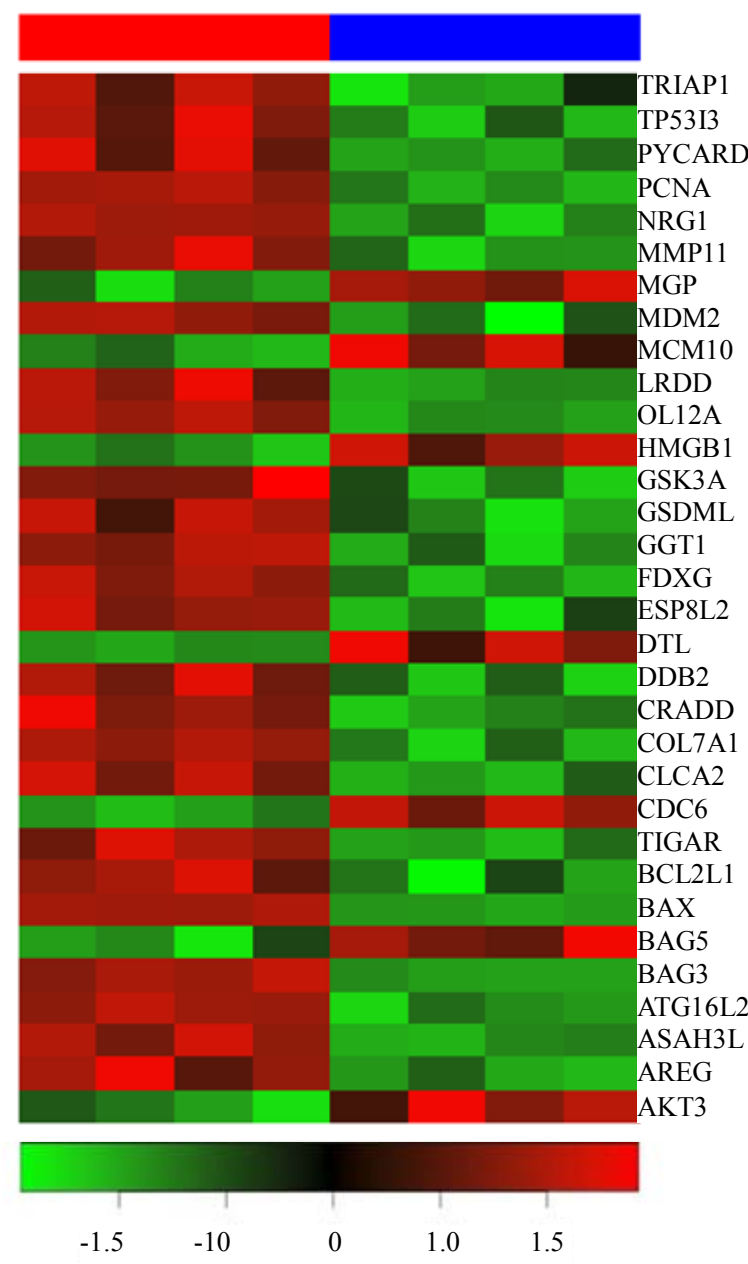

Figure 3. Heatmap of 37 selected genes in irradiated CAF samples are shown as red bar (top) and non-irradiated CAF samples as blue bar (top). Legend (bottom) shows the fold change $\left[\log _{2}\right.$ (radiated) - $\log _{2}$ (normal)] color coded values in the heatmap.

irradiation [14]. Our data show a potent and permanent induction of cell senescence after a single insult of $18 \mathrm{~Gy}$ and Figure 4 illustrates the acquisition of the senescent phenotype by CAFs after exposure to $18 \mathrm{~Gy}$.

One of the most drastically altered pathways after irradiation corresponded to DNA damage responses and chromatin rearrangements (Table 3). Previously we have conducted quantitative dose-dependent measurements of DNA damage and repair induced by IR on CAFs. In that study we show that IR provoke substantial DNA damage even at low radiation doses, however we saw that arising nuclear foci were able to resolve at radiation doses lower than 12 Gy. After a single dose with 18 Gy a strong and permanent DNA damage response on cells was established. An illustration of these observations is presented in Figure 5.

Intracellular levels of reactive oxygen species (ROS) were determined as described in detail in the Materials \& Methods. ROS production by CAFs was significantly increased in irradiated CAFs (Figure 6). Elevated ROS production has been found to be predominantly a consequence of altered mitochondrial gene expression (Table 4). Increased expression of cytochrome P450, family 3, subfamily A, polypeptide 7 (CYP3A4) and NADH adrenodoxin oxireductase (FDXR) was confirmed by qPCR (Table 2).

Genes associated with regulation of autophagy and apoptosis were also transformed after IR (Table 5 and Table 6). However, expression of apotopic genes like MDM2 p53 binding protein homolog (MDM2) and tumor protein p53 inducible protein 3 (TP53I3), and expression of ATG16 autophagy related 16-like 2 (ATG16L2) gene was confirmed by qPCR (Table 2).

In pilot experiments, apoptosis and autophagy were measured on CAFs at different points after IR by staining for annexin $\mathrm{V}$ on living cells and by using Cyto-ID Autophagy Detection Kit (ENZO life Sciences) respecttively (data not shown). These assays failed to show induction of neither apoptosis nor autophagy in CAFs for up to two weeks after exposure to $18 \mathrm{~Gy}$, indicating that the counter balance between the pro- and anti-signaling mechanisms prevented the ultimate induction of such pathways.
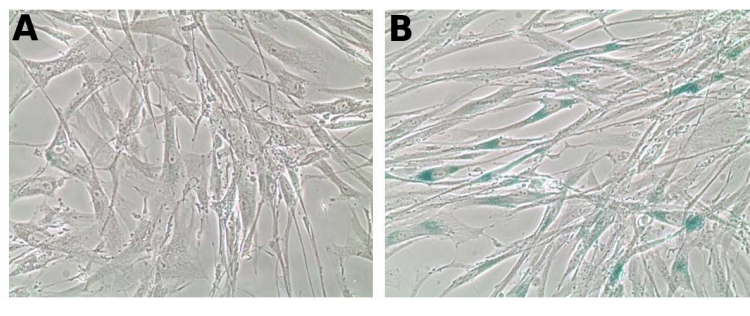

Figure 4. Induction of cellular senescence was determined by $\beta$-galactosidase staining assay. Adherent CAFs were irradiated $(1 \times 18 \mathrm{~Gy})$ and 5 days later examined for the expression of intra-cytoplasmic $\beta$-galactosidase. (A) control conditions (0 Gy); (B) irradiated cultures (18 Gy).
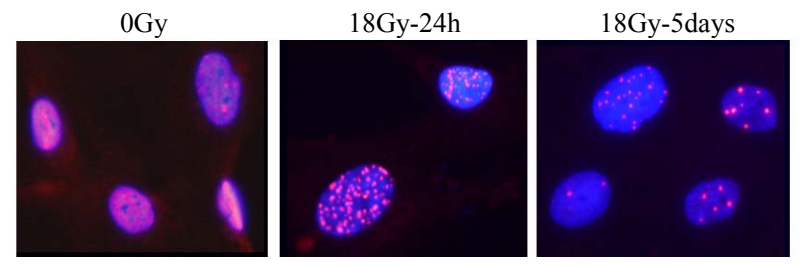

Figure 5. Persistent DDR (DNA Damage Response). Cells were immunostained for 53BP1 (red, Alexa546) and nuclei were stained with DAPI (Blue). Homogenous nuclear staining of 53BP1 was observed in non-irradiated cells, whereas numerous nuclear foci were observed 24 hours post-radiation. After five days most cells still demonstrated multiple nuclear foci, with a reduced number of foci when compared to earlier time points. 


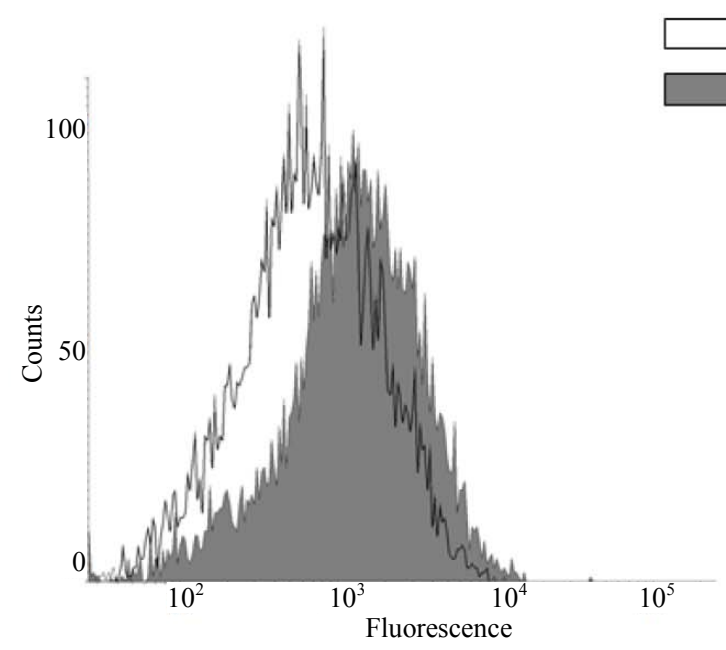

(a)
0 Gy

18 Gy
ROS Production

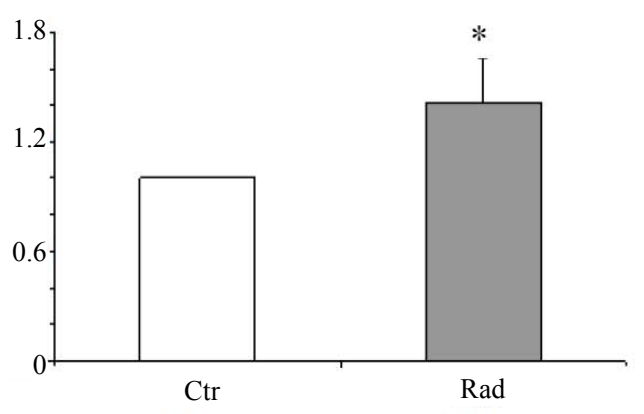

(b)

Figure 6. The intracellular ROS production was counted as total $\mathrm{H}_{2} \mathrm{O}_{2}$ accumulated in cells 24 hours after IR. $\mathrm{H}_{2} \mathrm{O}_{2}$ levels were determined in CAFs from 4 different donors by incubating cells with $2.5 \mathrm{mM}$ CM-H2DCFDA for 30 minutes followed by flow cytometric analyses. Ten thousand events were collected for each measurement and the mean values of the relative fluorescence were registered. Panels in (a) illustrate ROS staining in CAFs from one representative donor. Continuous lines correspond to fluorescence patterns in non-irradiated cells; filled peaks correspond to fluorescence intensity in irradiated cells. In (b), mean fluorescent intensities resulting from FACS analysis from four randomly selected donors is presented. Fluorescence intensity from non-irradiated cultures was averaged and normalized (open bars) whereas the irradiated counterparts are presented with $\mathrm{X}$-fold increase in surface labeling relative to control cells (filled bars). The asterix (*) indicates significant differences $(p<0.05)$ in mean values when compared to the levels in untreated cells.

In addition, the increased expression of genes involved in cell adhesion, collagen type VII alpha (COL7A1) and stromelysin 3 (MMP11), and the cytokine interleukin 12A (IL2A) has been confirmed accordingly (Table 2).

\section{Discussion}

The aim of this study was to examine the impact of high-dose ionizing radiation on activated cancer-associated fibroblasts (CAFs) and to predict the consequences of the induced changes on post-radiation tumorigenesis. The overall study showed that approximately $80 \%$ of all differentially expressed genes were up-regulated and 20 $\%$ were down-regulated after treatment (Supplemental list 1). In line with previous reports performed on normal tissue fibroblasts, our data show that a large extent of differentially expressed genes belongs to cellular mechanisms related to cell stress, cell cycle, apoptosis, DNA repair, and other pro-survival pathways. It is expected that ionizing radiation induces severe genotoxic stresses in cells, followed by alterations on the expression of genes involved in biological processes like DNA repair, cell proliferation, cell cycle, apoptosis and p53 pathway as has been also shown in a previous study with primary human skin fibroblasts [9]. Cell proliferation and cell cycle checkpoints are some of the pathways profoundly affected by ablative doses of ionizing radiation (AIR) on CAFs. Hence, a list of genes involved in cell cycle regu- lation such as cell division cycle homologs CDC6 and CDC34, proliferating cell nuclear antigen (PCNA) and different cylins are all up-regulated, whereas denticless protein homolog (DTL) and minichromosome maintenance component 10 (MCM10) are down-regulated (Table 3). Secondly, (RPA2), Mdm2 p53 binding protein homolog (MDM2), and damage-specific DNA binding protein 2 (DDB2), were both up-regulated. In line with our observations, an increased expression of cylins and PCNA has been also observed in normal fibroblasts after lower dose ionizing radiation [11]. In addition, many histones showed increased expression (Table 3). They do not only play an important role in transcription regulation, but are also important team players in DNA repair mechanisms by being responsible for sustaining chromosomal stability [23]. Putting it together, these data suggest that CAFs intend to counteract mitotic catastrophe after irradiation.

In normal fibroblast radiation exposure, as well as administration of genotoxic agents, are able to induce growth arrest, a phenomenon described as cellular senescence [24]. Senescence is often accompanied by stimuli like oxidative DNA damage, and a compromised replicative cell cycle [25]. Although cellular senescence can be ascribed as a self-regulated tumor suppressor mechanism, thereby protecting the organisms from developing cancer, it has been acknowledged that senescent 
stromal fibroblasts are able to expedite epithelial tumorigenesis [26]. Ionizing radiation of CAFs revealed differential expression of a considerable number of genes that are related to senescence and ageing. Candidate genes listed have been shown to be involved in sensecence at different extents (Table 1).

In our hands, high-dose ionizing radiation results in an increase of reactive oxygen species (ROS) formation in CAFs. The provoked enhanced ROS production is reflected by alterations in mainly mitochondrial-generated ROS rather than activation of the NADPH-oxidase (NOX) system (Figure 3 and Table 4). Of note, the disturbances in the redox homeostasis of irradiated CAFs have the potential to lead to increased tumor growth [27]. Previous studies have shown that normal fibroblasts express multiple ROS scavenger genes when irradiated with lower doses [13]. Here, enhanced expression was only observed for one ROS scavenger, namely gamma glutamyl transferase 1 (GGT1).

The expression of genes involved in the regulation of apoptosis was also modified after AIR, including both pro- and anti-apoptotic signaling pathways (Table 5). Thus, the transcription of genes involved in caspase-mediated apoptosis (caspase recruitment domain-containing protein (PYCARD) and caspase and RIP adapter with death domain (CRADD) was enhanced, which correlates with observations made in irradiated normal tissue fibroblast [11]. However, in our in vitro assays we could not observe apoptotic cells during the first two weeks post irradiation. Taken these observations together, we may conclude that the anti-apoptotic signals had stronger influence on the final outcomes on cells.

Of importance, a number of genes regulated by or connected to the tumor suppressor gene p53 were shown to be up- or down regulated. The observed over-expression of MDM2 can result in excessive inactivation of tumor protein $\mathrm{p} 53$ in CAFs, thereby diminishing its tumor suppressor function and therefore affecting tumorigenesis [28] or may act in a p53-independent manner as an oncogene [29]. It is hereby noted that nine different MDM2 transcripts showed increased expression levels (see also Supplemental list 1). Their functional and not yet defined biological implications on the tumor microenvironment still needs to be elucidated [30]. Increased expression levels for MDM2 variants have been reported to be related to radio-sensitivity in the lung [31], and implies the possibility that CAF to some extent become radio-resistant after treatment [32]. On the other hand, up-regulation of the TP53-induced glycolysis and apoptosis regulator (TIGAR) may protect irradiated CAFs against reactive oxigen species and apoptosis induced by TP53/p53. It has been shown that fibroblasts are also able to induce an up-regulation of TIGAR expression in cancer cells, thereby protecting cancer cells against apoptosis and autophagy, as recently described in an autophagic tumor stroma model of cancer [33].

Autophagy, which can be ascribed as both cell survival and cell death mechanism has been shown to be activated in tumor cells after ionizing radiation [34]. Here, enhanced expression of a large number of other genes related to autophagy has been observed (Table 6). A role for autophagy in CAFs has been recently shown to be linked to promotion of tumor cell survival [33]. However, the establishment of an autophagic response in CAFs after AIR still needs to be confirmed, and whether such stress-induced changes occurring in CAFs could have an impact on tumor cells also remains to be determined.

Pro-angiogenic signals released by CAFs contribute importantly to the overall sustainability of tumors $[35,36]$. However, the observed decreased expression of the proangiogenic factor angiopoietin 1 ANGPT1, a factor that mediates reciprocal interactions between the endothelium and surrounding matrix [37], might result in suppressed tumor growth. Several anti-angiogenic molecules showed increased expression in CAFs after highdose ionizing radiation which might have a direct impact on tumor growth. The matrix-derived angiogenesis inhibitor thrombospondin type I, domain containing 1 (THSD 1) [38], which is able to confer signals like thrombospondin 1 [39-41], and interleukin 12A (IL-12A) [42], both may be able to reduce tumor growth rate. In contrast, several semaphorin receptors which are able to confer both, pro- and anti-angiogenic signals are differentially expressed in irradiated CAFs (Table 7). The observed differential expression of plexins PLXNB1, PLXNB3 and PLXA4B imply a role for CAFs on endothelial cell migration [43]. Their role in normal lung and in invasive growth and cell migration in lung cancer has been discussed $[44,46]$. Interestingly, the activation of PLXNB1 and PLXNB3 in irradiated CAFs might inhibit integrin-based adhesion and cell migration on the ECM as has been reported earlier for normal fibroblasts [47].

Together with immune cells, fibroblasts are able to support the survival of the tumor [48,49]. Although many genes involved in signaling pathways for growth factors (i.e. EGF/EGFR) have been identified in CAFs [48-51], a differential expression of these particular growth factors or receptors has not been observed by us. Interestingly, two members of the epidermal growth factor (EGF) family downstream of the EGF receptor pathway have been found with increased expression in irradiated CAFs: the autocrine growth factor and mitogen for fibroblasts amphiregulin (AREG), and epidermal growth factor recaptor pathway substrate 8-related protein 2 (EPS8L2). Increased expression of AREG might have an effect on 
tumor growth since it has been shown that AREG can inhibit growth and apoptosis in certain aggressive adenoma cell lines in culture [52]. However, increased expression of EPS8 has been linked to progression of squamous carcinogenesis and might confer pro-tumorigenic effects on the surrounding tumor tissue [53]. It is therefore tempting to speculate that alternative signaling mechanisms may deregulate EGFR signaling during carcinogenesis, such as over-expression or activation of EGF/EGFR pathway intermediates.

CAFs express extracellular matrix (ECM) proteins and matrix regulatory agents, thereby providing a favourable microenvironment for cancer cells which is followed by a stimulation of proliferation of tumors and metastasis [54-56]. The increased expression of collagen type VII, alpha COL7A1 might sustain the stability of the cellular organization within the tumor microenvironment by contributing to epithelial basement membrane organization and adherence by interacting with ECM proteins. On the other hand, the matrix metalloproteinase 11 (stromelysin 3) (MMP11) is the solely significant differentially exessed matrix metalloproteinase after irradiation. The enhanced expression of MMP11 in CAFs could promote cancer progression by remodeling the ECM and confers anti-apoptotic and anti-necrotic effects on tumor cells [57]. Numerous studies have linked increased MMP11 expression in different human cancers with poor disease prognosis $[58,59]$, and have been recently suggested to represent a new prognostic indicator for gastric cancer [60]. In addition, the ECM protein Gla protein (MGP) showed decreased expression which can be associated with poor prognosis of lung cancer as has been recently reported for colorectal adearcinoma [61]. A potential role for MGP as a prognostic marker for breast cancer has also been implied [62]. Increased expression levels of multiple splice variants for neuregulin-1 (NRG1) in CAFs (see also Supplemental list 1) might have an impact on neighboring epithelial cells by inducing their growth and differentiation $[63,64]$. Elevated expression of gasdermin B (GSDMB) imply a regulatory role for irradiated CAFs on the adjacent epithelial cells, as augnted expression of GSDML has been correlated to cancer progression in the gastric epithelium [65].

In conclusion, CAFs are able to survive ablative radiation doses, but such insult provoke prominent cellular damages and consequently numerous genes implicated in DNA repair, cellular stress and cell survival pathways are activated. Our analyses show that CAFs display both proand anti-tumorigenic effects after having received a single high-dose of ionizing radiation. These effects might have an impact on the tumor microenvironment in respect to tumor growth and metastasis. The complexity of the observed differential gene expression patterns and implicative biological effects are interesting future objecttives for further elucidations.

\section{Acknowledgements}

Funding was provided by the North Norway Regional Health Authority (Helse Nord) and Aakre Foundation. Microarray experiments were conducted at the Microarray Resource Centre Tromsø (MRCT), which is supported by the National Program for Research and Functional Genomics in Norway (FUGE), University of Tromsø and University Hospital North Norway. The authors have no potential conflicts of interest to disclose.

\section{REFERENCES}

[1] J. H. Heinzerling, B. Kavanagh and R. D. Timmerman, "Stereotactic Ablative Radiation Therapy for Primary Lung Tumors," Cancer Journal, Vol. 17, No. 1, 2011, pp. 28-32. doi:10.1097\%2FPPO.0b013e31820a7f80

[2] D. Palma and S. Senan, "Stereotactic Radiation Therapy: Changing Treatment Paradigms for Stage I Non Small Cell Lung Cancer," Current Opinion in Oncology, Vol. 23, No. 2, 2011, pp. 133-139. doi:10.1097\%2FCCO.0b013e328341ee11

[3] B. D. Kavanagh, M. Miften and R. A. Rabinovitch, "Advances in Treatment Techniques: Stereotactic Body Radiation Therapy and the Spread of Hypofractionation," Cancer Journal, Vol. 17, No. 3, 2011, pp. 177-181. doi:10.1097\%2FPPO.0b013e31821f7dbd

[4] T. B. Lanni Jr., I. S. Grills, L. L. Kestin and J. M. Robertson, "Stereotactic Radiotherapy Reduces Treatment Cost while Improving Overall Survival and Local Control over Standard Fractionated Radiation Therapy for Medically Inoperable Non-Small-Cell Lung Cancer," American Journal of Clinical Oncology, Vol. 34, No. 5, 2011, pp. 494-498. doi:10.1097\%2FCOC.0b013e3181ec63ae

[5] M. P. Lisanti, U. E. Martinez-Outschoorn, B. Chiavarina, S. Pavlides, D. Whitaker-Menezes, A. Tsirigos, A. Witkiewicz, Z. Lin, R. Balliet, A. Howell and F. Sotgia, "Understanding the 'Lethal' Drivers of Tumor-Stroma Co-Evolution: Emerging Role(s) for Hypoxia, Oxidative Stress and Autophagy/Mitophagy in the Tumor MicroEnvironment," Cancer Biology and Therapy, Vol. 10, No. 6, 2010, pp. 537-542. doi:10.4161\%2Fcbt.10.6.13370

[6] K. Pietras and A. Ostman, "Hallmarks of Cancer: Interactions with the Tumor Stroma," Experimental Cell Research, Vol. 316, No. 8, 2010, pp. 1324-1331. doi:10.1016\%2Fj.yexcr.2010.02.045

[7] M. Allen and J. L. Jones, "Jekyll and Hyde: The Role of the Microenvironment on the Progression of Cancer," The Journal of Pathology, Vol. 223, No. 2, 2011, pp. 162-176.

[8] K. Räsänen and A. Vaheri, "Activation of Fibroblasts in Cancer Stroma," Experimental Cell Research, Vol. 316, No.17, 2010, pp. 2713-2722. doi:10.1016\%2Fj.yexcr.2010.04.032

[9] E. Kis, T. Szatmari, M. Keszei, R. Farkas, O. Esik, K. 
Lumniczky, A. Falus and G. Safrany, "Microarray Analysis of Radiation Response Genes in Primary Human Fibroblasts," International Journal of Radiation Oncology, Biology, Physics, Vol. 66, No. 5, 2006, pp. 1506-1514. doi:10.1016\%2Fj.ijrobp.2006.08.004

[10] S. Tachiiri, T. Katagiri, T. Tsunoda, N. Oya, M. Hiraoka and Y. Nakamura, "Analysis of Gene-Expression Profiles after Gamma Irradiation of Normal Human Fibroblasts," International Journal of Radiation Oncology, Biology, Physics, Vol. 64, No. 1, 2006, pp. 272-279. doi:org/10.1016\%2Fj.ijrobp.2005.08.030

[11] O. K. Rødningen, J. Øvergaard, J. Alsner, T. Hastie and A. L. Børresen-Dale, "Microarray Analysis of the Transcriptional Response to Single or Multiple Doses of Ionizing Radiation in Human Subcutaneous Fibroblasts," Radiotherapy and Oncology, Vol. 77, No. 3, 2005, pp. 231-240. doi:10.1186\%2Fbcr1151

[12] H. Landmark, S. A. Nahas, J. Aaroe, R. Gatti, A. L. Borresen-Dale and O. K. Rodningen, "Transcriptional Response to Ionizing Radiation in Human Radiation Sensitive Cell Lines," Radiotherapy and Oncology, Vol. 83, No. 3, 2007, pp. 256-260.

[13] O. K. Rødningen, A. L. Børresen-Dale, J. Alsner, T. Hastie and J. øvergaard, "Radiation-Induced Gene Expression in Human Subcutaneous Fibroblasts is Predictive of Radiation-Induced Fibrosis," Radiotherapy and Oncology, Vol. 86, No. 3, 2008, pp. 314-320.

doi:10.1016\%2Fj.radonc.2007.09.013

[14] T. Hellevik, I. Pettersen, V. Berg, J. O. Winberg, B. T. Moe, K. Bartnes, R. H. Paulssen, L. T. Busund, R. Bremnes, A. Chalmers and I. Martinez-Zubiaurre, "CancerAssociated Fibroblasts from Human NSCLC Survive Ablative Doses of Radiation but Their Invasive Capacity is Reduced," Radiation Oncology, Vol. 7, No. 1, 2012, pp. 59-71. doi:10.1186\%2F1748-717X-7-59

[15] S. Stathakis, J. S. Li, K. Paskalev, J. Yang, L. Wang and C. M. Ma, "Ultra-Thin TLDs for Skin Dose Determination in High Energy Photon Beams," Physics in Medicine and Biology, Vol. 51, No. 14, 2006, pp. 3549-3567. doi:10.1088\%2F0031-9155\%2F51\%2F14\%2F018

[16] T. Mosmann, "Rapid Colorimetric Assay for Cellular Growth and Survival: Application to Proliferation and Cytotoxicity Assays," Journal of Immunological Methods, Vol. 65, No. 1-2, 1983, pp. 55-63. doi: $10.1016 \% 2 \mathrm{~F} 0022-1759 \% 2883 \% 2990303-4$

[17] R. H. Paulssen, L. Olsen and T. C. Sogn, "MagNa Pure Compact RNA Isolation Kit: Isolation of High-Quality Total RNA from a Broad Range of Sample Material," Biochemica, Vol. 2, 2006, pp. 14-16.

[18] B. M. Bolstad, R. A. Irizarry, M. Astrand and T. P. Speed, "A Comparison of Normalization Methods for High Density Oligonucleotide Array Data Based on Variance and Bias," Bioinformatics, Vol. 19, No. 2, 2003, pp. 185-193. doi:10.1093\%2Fbioinformatics\%2F19.2.185

[19] G. K. Smyth, "Linear Models and Empirical Bayes Methods for Assessing Differential Expression in Microarray Experiments," Statistical Applications in Genetics and Molecular Biology, Vol. 3, No. 1, 2004, pp. 1544-6115.

\section{doi:10.2202\%2F1544-6115.1027}

[20] Y. Benjamini and D. Yekutieli, "False Discovery RateAdjusted Multiple Confidence Intervals for Selected Parameters," Journal of the American Statistical Association, Vol. 100, No. 469, 2005, pp. 71-81 doi: $10.1198 \% 2 \mathrm{~F} 016214504000001907$

[21] L. Gidskehaug, H. Stodkilde-Jorgensen, M. Martens and H. Martens, "Bridge-PLS Regression: Two-Block Bilinear Regression without Deflation," Journal of Chemometrics, Vol. 18, No. 3-4, 2004, pp. 208-215. doi: $10.1002 \% 2$ Fcem. 862

[22] K. J. Livak and T. D. Schmittgen, "Analysis of Relative Gene Expression Data using Real-Time Quantitative PCR and The 2(-Delta Delta C(T)) Method," Methods, Vol. 25, No. 4, 2001, pp. 402-408.

[23] G. Li and D. Reinberg, "Chromatin Higher-Order Structures and Gene Regulation," Current Opinion in Genetics \& Development, Vol. 21, No. 2, 2011, pp. 175-186. doi:10.1016\%2Fj.gde.2011.01.022

[24] A. Krtolica, S. Parrinello, S. Lockett, P. Y. Desprez and J. Campisi, "Senescent Fibroblasts Promote Epithelial Cell Growth and Tumorigenesis: A Link Between Cancer and Aging," Proceedings of the National Academy of Sciences of the United States of America, Vol. 98, No. 21, 2001, pp. 12072-12077. doi:10.1073\%2Fpnas. 211053698

[25] J. L. Wang and P. C. Wang, "The Effect of Aging on the DNA Damage and Repair Capacity in 2BS Cells Undergoing Oxidative Stress," Molecular Biology Reports, Vol. 39, No. 1, 2012, pp. 233-241. doi:10.1007\%2Fs11033-011-0731-4

[26] C. Bavik, I. Coleman, J. P. Dean, B. Knudsen, S. Plymate and P. S. Nelson, "The Gene Expression Program of Prostate Fibroblast Senescence Modulates Neoplastic Epithelial Cell Proliferation through Paracrine Mechanisms," Cancer Research, Vol. 66, No. 2, 2006, pp. 794-802. doi:10.1158\%2F0008-5472.CAN-05-1716

[27] T. B. Kryston, A. B. Georgiev, P. Pissis and A. G. Georgakilas, "Role of Oxidative Stress and DNA Damage in Human Carcinogenesis," Mutation Research, Vol. 711, No. 1-2, 2011, pp. 193-201. doi:10.1016\%2Fj.mrfmmm.2010.12.016

[28] P. L. Miliani de Marval and Y. Zhang, "The RP-Mdm2p53 Pathway and Tumorigenesis," Oncotarget, Vol. 2, No. 3, 2011, pp. 234-238.

[29] J. J. Manfredi, "The Mdm2-p53 Relationship Evolves: Mdm2 Swings Both Ways as an Oncogene and a Tumor Suppressor," Genes \& Development, Vol. 24, No. 15, 2010, pp. 1580-1589. doi:10.1101\%2Fgad. 1941710

[30] L. C. Harris, "MDM2 Splice Variants and Their Therapeutic Implications," Current Cancer Drug Targets, Vol. 5, No. 1, 2005, pp. 21-26. doi: $10.2174 \% 2 \mathrm{~F} 1568009053332654$

[31] K. Ogawa, S. Murayama and M. Mori, "Predicting the Tumor Response to Radiotherapy Using Microarray Analysis," Oncology Reports, Vol. 18, No. 5, 2007, pp. 1243 1248.

[32] W. F. Guo, R. X. Lin, J. Huang, Z. Zhou, J. Yang, G. Z. 
Guo and S. Q. Wang, "Identification of Differentially Expressed Genes Contributing to Radioresistance in Lung Cancer Cells Using Microarray Analysis," Radiation Research, Vol. 164, No. 1, 2005, pp. 27-35.

doi:10.1667\%2FRR3401

[33] U. E. Martinez-Outschoorn, S. Pavlides, A. Howell, R. G. Pestell, H. B. Tanowitz, F. Sotgia and M. P. Lisanti, "Stromal-Epithelial Metabolic Coupling in Cancer: Integrating Autophagy and Metabolism in the Tumor Microenvironment," The International Journal of Biochemistry \& Cell Biology, Vol. 43, No. 7, 2011, pp. 1045-1051. doi:10.1016\%2Fj.biocel.2011.01.023

[34] H. Chaachouay, P. Ohneseit, M. Toulany, R. Kehlbach, G. Multhoff and H. P. Rodemann, "Autophagy Contributes to Resistance of Tumor Cells to Ionizing Radiation," $R a$ diotherapy and Oncology, Vol. 99, No. 3, 2011, pp. 287292. doi:10.1016\%2Fj.radonc.2011.06.002

[35] M. Ao, O. E. Franco, D. Park, D. Raman, K. Williams and S. W. Hayward, "Cross-Talk between ParacrineActing Cytokine and Chemokine Pathways Promotes Malignancy in Benign Human Prostatic Epithelium," Cancer Research, Vol. 67, No. 9, 2007, pp. 4244-4253. doi:10.1158\%2F0008-5472.CAN-06-3946

[36] R. F. Hwang, T. Moore, T. Arumugam, V. Ramachandran, K. D. Amos, A. Rivera, B. Ji, D. B. Evans and C. D. Logsdon, "Cancer-Associated Stromal Fibroblasts Promote Pancreatic Tumor Progression," Cancer Research, Vol. 68, No. 3, 2008, pp. 918-926. doi:10.1158\%2F0008-5472.CAN-07-5714

[37] A. D. Blann, K. S. Ramcharan, P. S. Stonelake, D. Luesley and G. Y. Lip, "The Angiome: A New Concept in Cancer Biology," Journal of Clinical Pathology, Vol. 64, No. 7, 2011, pp. 637-643. doi:10.1136\%2Fjcp.2011.088948

[38] J. M. Ko, P. L. Chan, W. L. Yau, H. K. Chan, K. C. Chan, Z. Y. Yu, F. M. Kwong, L. D. Miller, E. T. Liu, L. C. Yang, P. H. Lo, E. J. Stanbridge, J. C. Tang, G. Srivastava, S. W. Tsao, S. Law and M. L. Lung, "Monochromosome Transfer and Microarray Analysis Identify a Critical Tumor-Suppressive Region Mapping to Chromosome 13q14 and THSD1 in Esophageal Carcinoma," Molecular Cancer Research, Vol. 6, No. 4, 2008, pp. 592-603. doi:10.1158\%2F1541-7786.MCR-07-0154

[39] L. C. Armstrong and P. Bornstein, "Thrombospondins 1 and 2 Function as Inhibitors of Angiogenesis," Matrix Biology, Vol. 22, No. 1, 2003, pp. 63-71. doi: $10.1016 \% 2$ FS0945-053X\%2803\%2900005-2

[40] P. Bornstein, "Thrombospondins Function as Regulators of Angiogenesis," Journal of Cell Communication and Signaling, Vol. 3, No. 3-4, 2009, pp. 189-200. doi: $10.1007 \% 2$ Fs 12079-009-0060-8

[41] F. de Fraipont, A. C. Nicholson, J. J. Feige and E. G. Van Meir, "Thrombospondins and Tumor Angiogenesis," Trends in Molecular Medicine, Vol. 7, No. 9, 2001, pp. 401-407. doi: $10.1016 \% 2 \mathrm{FS} 1471-4914 \% 2801 \% 2902102-5$

[42] F. Cavallo, E. Quaglino, L. Cifaldi, E. Di Carlo, A. Andre, P. Bernabei, P. Musiani, G. Forni and R. A. Calogero,
"Interleukin 12-Activated Lymphocytes Influence Tumor Genetic Programs," Cancer Research, Vol. 61, No. 8, 2001, pp. 3518-3523.

[43] A. Sakurai, C. Doci and J. S. Gutkind, "Semaphorin Signaling in Angiogenesis, Lymphangiogenesis and Cancer," Cell Research, Vol. 22, No. 1, 2012, pp. 23-32. doi: $10.1038 \% 2 \mathrm{Fcr} .2012 .21$

[44] T. Ito, M. Kagoshima, Y. Sasaki, C. Li, N. Udaka, T. Kitsukawa, H. Fujisawa, M. Taniguchi, T. Yagi, H. Kitamura and Y. Goshima, "Repulsive Axon Guidance Molecule Sema3A Inhibits Branching Morphogenesis of Fetal Mouse Lung," Mechanisms of Development, Vol. 97, No. 1-2, 2000, pp. 35-45. doi: $10.1016 \% 2$ FS0925-4773\%2800\%2900401-9

[45] M. Kagoshima and T. Ito, "Diverse Gene Expression and Function of Semaphorins in Developing Lung: Positive and Negative Regulatory Roles of Semaphorins in Lung Branching Morphogenesis," Genes to Cells: Devoted to Molecular and Cellular Mechanisms, Vol. 6, No. 6, 2001, pp. 559-571. doi:10.1046\%2Fj.1365-2443.2001.00441.x

[46] V. A. Potiron, J. Roche and H. A. Drabkin, "Semaphorins and Their Receptors in Lung Cancer," Cancer Letters, Vol. 273, No. 1, 2009, pp. 1-14. doi:10.1016\%2Fj.canlet.2008.05.032

[47] D. Barberis, S. Artigiani, A. Casazza, S. Corso, S. Giordano, C. A. Love, E. Y. Jones, P. M. Comoglio and L. Tamagnone, "Plexin Signaling Hampers Integrin-Based Adhesion, Leading to Rho-Kinase Independent Cell Rounding, and Inhibiting Lamellipodia Extension and Cell Motility," FASEB Journal, Vol. 18, No. 3, 2004, pp. 592-594.

[48] N. A. Bhowmick, E. G. Neilson and H. L. Moses, "Stromal Fibroblasts in Cancer Initiation and Progression," Nature, Vol. 432, No. 7015, 2004, pp. 332-337. doi: $10.1038 \% 2$ Fnature 03096

[49] M. Akdis, S. Burgler, R. Crameri, T. Eiwegger, H. Fujita, E. Gomez, S. Klunker, N. Meyer, L. O’Mahony, O. Palomares, C. Rhyner, N. Ouaked, A. Schaffartzik, W. Van De Veen, S. Zeller, M. Zimmermann and C. A. Akdis, "Interleukins, from 1 to 37, and Interferon-Gamma: Receptors, Functions, and Roles in Diseases," The Journal of Allergy and Clinical Immunology, Vol. 127, No. 3, 2011, pp. 701-721. doi:10.1016\%2Fj.jaci.2010.11.050

[50] R. Kalluri and M. Zeisberg, "Fibroblasts in Cancer," Nature Reviews. Cancer, Vol. 6, No. 5, 2006, pp. 392-401. doi:10.1038\%2Fnrc1877

[51] H. Nakagawa, S. Liyanarachchi, R. V. Davuluri, H. Auer, E. W. Martin Jr., A. de la Chapelle and W. L. Frankel, "Role of Cancer-Associated Stromal Fibroblasts in Metastatic Colon Cancer to the Liver and Their Expression Profiles," Oncogene, Vol. 23, No. 44, 2004, pp. 73667377. doi: $10.1038 \% 2 F s j . o n c .1208013$

[52] A. Hurbin, L. Dubrez, J. L. Coll and M. C. Favrot, "Inhibition of Apoptosis by Amphiregulin via an Insulin-Like Growth Factor-1 Receptor-Dependent Pathway in NonSmall Cell Lung Cancer Cell Lines," The Journal of Biological Chemistry, Vol. 277, No. 51, 2002, pp. 4912749133. doi: $10.1074 \% 2 F j b c . M 207584200$ 
[53] H. Wang, V. Patel, H. Miyazaki, J. S. Gutkind and W. A. Yeudall, "Role for EPS8 in Squamous Carcinogenesis," Carcinogenesis, Vol. 30, No. 1, 2009, pp. 165-174. doi:10.1016\%2Fj.oos.2009.06.212

[54] J. A. Joyce and J. W. Pollard, "Microenvironmental Regulation of Metastasis," Nature Reviews. Cancer, Vol. 9, No. 4, 2009, pp. 239-252.

[55] M. Liu, J. Xu and H. Deng, "Tangled Fibroblasts in Tumor-Stroma Interactions," International Journal of Cancer, Vol. 129, No. 8, 2011, pp. 1795-1805. doi: $10.1002 \% 2$ Fijc. 26116

[56] L. E. Littlepage, M. D. Sternlicht, N. Rougier, J. Phillips, E. Gallo, Y. Yu, K. Williams, A. Brenot, J. I. Gordon and Z. Werb, "Matrix Metalloproteinases Contribute Distinct Roles in Neuroendocrine Prostate Carcinogenesis, Metastasis, and Angiogenesis Progression," Cancer Research, Vol. 70, No. 6, 2010, pp. 2224-2234. doi:10.1158\%2F0008-5472.CAN-09-3515

[57] P. Basset, C. Wolf and P. Chambon, "Expression of the Stromelysin-3 Gene in Fibroblastic Cells of Invasive Carcinomas of the Breast and Other Human Tissues: A Review," Breast Cancer Research and Treatment, Vol. 24, No. 3, 1993, pp. 185-193. doi:10.1007\%2FBF01833259

[58] D. Peruzzi, F. Mori, A. Conforti, D. Lazzaro, E. De Rinaldis, G. Ciliberto, N. La Monica and L. Aurisicchio, "MMP11: A Novel Target Antigen for Cancer Immunoerapy," Clinical Cancer Research, Vol. 15, No. 12, 2009 , pp. 4104-4113. doi:10.1158\%2F1078-0432.CCR-08-3226

[59] C. W. Cheng, J. C. Yu, H. W. Wang, C. S. Huang, J. C. Shieh, Y. P. Fu, C. W. Chang, P. E. Wu and C. Y. Shen, "The Clinical Implications of MMP-11 and CK-20 Expression in Human Breast Cancer," Clinica Chimica Acta,
Vol. 411, No. 3-4, 2010, pp. 234-241. doi:10.1016\%2Fj.cca.2009.11.009

[60] Z. S. Zhao, Y. Q. Chu, Z. Y. Ye, Y. Y. Wang and H. Q. Tao, "Overexpression of Matrix Metalloproteinase 11 in Human Gastric Carcinoma and Its Clinicopathologic Significance," Human Pathology, Vol. 41, No. 5, 2010, pp. 686-696. doi:10.1016\%2Fj.humpath.2009.10.010

[61] C. Fan, D. Sheu, H. Fan, K. Hsu, C. Allen Chang and E. Chan, "Down-Regulation of Matrix Gla Protein Messenger RNA in Human Colorectal Adenocarcinomas," Cancer Letters, Vol. 165, No. 1, 2001, pp. 63-69. doi:10.1016\%2FS0304-3835\%2801\%2900416-5

[62] K. Yoshimura, K. Takeuchi, K. Nagasaki, S. Ogishima, H. Tanaka, T. Iwase, F. Akiyama, Y. Kuroda and Y. Miki, "Prognostic Value of Matrix Gla Protein in Breast Cancer," Molecular Medicine Reports, Vol. 2, No. 4, 2009, pp. 549-553. doi:10.3892\%2Fmmr_00000135

[63] J. C. Montero, R. Rodriguez-Barrueco, A. Ocana, E. DiazRodriguez, A. Esparis-Ogando and A. Pandiella, "Neuregulins and Cancer," Clinical Cancer Research, Vol. 14, No. 11, 2008, pp. 3237-3241. doi:10.1158\%2F1078-0432.CCR-07-5133

[64] N. V. Hayes and W. J. Gullick, "The Neuregulin Family of Genes and Their Multiple Splice Variants in Breast Cancer," Journal of Mammary Gland Biology and Neoplasia, Vol. 13, No. 2, 2008, pp. 205-214. doi: $10.1007 \% 2$ Fs 10911-008-9078-4

[65] H. Komiyama, A. Aoki, S. Tanaka, H. Maekawa, Y. Kato, R. Wada, T. Maekawa, M. Tamura and T. Shiroishi, "Alu-Derived Cis-Element Regulates TumorigenesisDependent Gastric Expression of GASDERMIN B (GSDMB)," Genes \& Genetic Systems, Vol. 85, No. 1, 2010, pp. 75-83. doi:10.1266\%2Fggs.85.75 


\section{Supplement}

Supplemental list 1. Differentially expressed genes in irradiated cancer-associated fibroblasts.

\begin{tabular}{|c|c|c|c|c|c|}
\hline abi & gene & $\mathrm{p}$ value & adjusted $\mathrm{p}$ value & fold & diff \\
\hline NM_138763 & BAX & $1.81 \mathrm{E}-009$ & $8.17 \mathrm{E}-005$ & 0.768024 & 1.702935451 \\
\hline NM_198947 & FAM111B & $1.02 \mathrm{E}-007$ & 0.002286929 & -2.58423 & -5.996961141 \\
\hline ВC024648 & PHPT1 & $2.72 \mathrm{E}-007$ & 0.003977702 & 0.684596 & 1.607251359 \\
\hline AL137582 & BAG3 & $3.53 \mathrm{E}-007$ & 0.003977702 & 0.775614 & 1.711918429 \\
\hline NM_013960 & NRG1 & $5.27 \mathrm{E}-007$ & 0.004743616 & 2.464606 & 5.519760939 \\
\hline BC107485 & NEURL2 & $8.86 \mathrm{E}-007$ & 0.006652829 & 1.363829 & 2.5736732 \\
\hline NM_000882 & IL12A & $1.18 \mathrm{E}-006$ & 0.007551732 & 1.619253 & 3.072159968 \\
\hline NM_005393 & PLXNB3 & $1.44 \mathrm{E}-006$ & 0.007551732 & 1.761463 & 3.390418511 \\
\hline NM_014010 & ASTN2 & $1.52 \mathrm{E}-006$ & 0.007551732 & 1.446603 & 2.725654531 \\
\hline NM_182649 & PCNA & $1.95 \mathrm{E}-006$ & 0.007551732 & 1.728062 & 3.312825093 \\
\hline ВC012163 & MRPL53 & $2.05 \mathrm{E}-006$ & 0.007551732 & 0.626831 & 1.544169132 \\
\hline NM_003512 & HIST1H2AC & $2.30 \mathrm{E}-006$ & 0.007551732 & 0.853099 & 1.806377242 \\
\hline NM_006014 & XX-FW81657B9.4 & $2.40 \mathrm{E}-006$ & 0.007551732 & 0.877515 & 1.837208096 \\
\hline NM_005762 & TRIM28 & $2.40 \mathrm{E}-006$ & 0.007551732 & 0.477001 & 1.391847027 \\
\hline NM_015657 & ABCA12 & $2.52 \mathrm{E}-006$ & 0.007551732 & 1.634961 & 3.105792397 \\
\hline NM_002756 & MAP2K3 & $3.28 \mathrm{E}-006$ & 0.009231482 & 0.573737 & 1.488373917 \\
\hline NM_198188 & ASTN2 & $3.51 \mathrm{E}-006$ & 0.009303796 & 1.82306 & 3.538308168 \\
\hline ВС065913 & ASB6 & 4.24E-006 & 0.010612757 & 0.809592 & 1.752715705 \\
\hline BC053682 & COTL1 & $4.54 \mathrm{E}-006$ & 0.010752587 & 0.565244 & 1.479637227 \\
\hline $\mathrm{BC} 032503$ & ANAPC2 & $5.46 \mathrm{E}-006$ & 0.011440042 & 0.969125 & 1.957652542 \\
\hline NM_000251 & MSH2 & $5.90 \mathrm{E}-006$ & 0.011440042 & -0.5434 & -1.457400956 \\
\hline NM_013958 & NRG1 & $6.29 \mathrm{E}-006$ & 0.011440042 & 2.788939 & 6.911211173 \\
\hline XM_928391 & LOC653611 & $6.48 \mathrm{E}-006$ & 0.011440042 & 1.046302 & 2.065229185 \\
\hline NM_032431 & SYVN1 & $6.73 \mathrm{E}-006$ & 0.011440042 & 0.625822 & 1.543089849 \\
\hline ВС007015 & CCNE2 & $6.99 \mathrm{E}-006$ & 0.011440042 & -2.15266 & -4.446476235 \\
\hline NM_133172 & APBB3 & 7.07E-006 & 0.011440042 & 0.703604 & 1.628568141 \\
\hline ВC003080 & HSPC171 & $7.30 \mathrm{E}-006$ & 0.011440042 & 0.655253 & 1.574892306 \\
\hline NM_006271 & $\mathrm{S} 100 \mathrm{~A} 1$ & $7.71 \mathrm{E}-006$ & 0.011440042 & 0.716574 & 1.643275218 \\
\hline NM_001014987 & LAT & 7.72E-006 & 0.011440042 & 0.896101 & 1.861029934 \\
\hline BC108737 & HIST1H2BK & 7.72E-006 & 0.011440042 & 1.345575 & 2.541314945 \\
\hline AK026810 & TAF7L & $8.14 \mathrm{E}-006$ & 0.011440042 & 2.562542 & 5.907477687 \\
\hline AK057029 & HTF9C & $8.23 \mathrm{E}-006$ & 0.011440042 & 0.686178 & 1.609015677 \\
\hline NM_181738 & PRDX2 & $8.44 \mathrm{E}-006$ & 0.011440042 & 0.463577 & 1.378956969 \\
\hline ВC005896 & HYAL3 & 8.64E-006 & 0.011440042 & 1.320064 & 2.496772504 \\
\hline
\end{tabular}


Continued

\begin{tabular}{|c|c|c|c|c|c|}
\hline NM_006878 & MDM2 & $9.39 \mathrm{E}-006$ & 0.01177774 & 1.222556 & 2.333598241 \\
\hline ВC092487 & ASAH3L & $9.42 \mathrm{E}-006$ & 0.01177774 & 1.740934 & 3.342516066 \\
\hline NM_033388 & ATG16L2 & $1.01 \mathrm{E}-005$ & 0.01202843 & 0.924626 & 1.898191986 \\
\hline NM_006232 & POLR2H & $1.01 \mathrm{E}-005$ & 0.01202843 & 0.700125 & 1.624645442 \\
\hline BC101544 & GRIPAP1 & $1.10 \mathrm{E}-005$ & 0.012696458 & 0.719984 & 1.647163924 \\
\hline AF385325 & MDM2 & $1.13 \mathrm{E}-005$ & 0.012696458 & 1.387494 & 2.61623886 \\
\hline NM_013962 & NRG1 & $1.19 \mathrm{E}-005$ & 0.012840948 & 2.424391 & 5.368023002 \\
\hline NM_002392 & MDM2 & $1.20 \mathrm{E}-005$ & 0.012840948 & 0.933639 & 1.910088158 \\
\hline NM_002434 & MPG & $1.35 \mathrm{E}-005$ & 0.014091567 & 0.631122 & 1.548768522 \\
\hline BC000298 & NINJ1 & $1.43 \mathrm{E}-005$ & 0.014647145 & 1.003179 & 2.004411248 \\
\hline AK023030 & JMJD4 & $1.54 \mathrm{E}-005$ & 0.015141866 & 0.717407 & 1.644224074 \\
\hline $\mathrm{BC} 013685$ & MRPL2 & $1.55 \mathrm{E}-005$ & 0.015141866 & 0.604732 & 1.520696638 \\
\hline ВC011762 & CYFIP2 & $1.62 \mathrm{E}-005$ & 0.015558825 & 2.040759 & 4.114618331 \\
\hline NM_001254 & CDC6 & $1.67 \mathrm{E}-005$ & 0.015635117 & -1.65638 & -3.152240503 \\
\hline XM_929083 & LOC653319 & $1.78 \mathrm{E}-005$ & 0.015950766 & 0.65515 & 1.574779228 \\
\hline ВC018722 & ASPSCR1 & $1.79 \mathrm{E}-005$ & 0.015950766 & 0.49265 & 1.407027358 \\
\hline NM_013964 & NRG1 & $1.87 \mathrm{E}-005$ & 0.015950766 & 2.052564 & 4.148427122 \\
\hline XM_929687 & LOC646739 & $1.90 \mathrm{E}-005$ & 0.015950766 & 2.057284 & 4.162020136 \\
\hline NM_004110 & FDXR & $1.91 \mathrm{E}-005$ & 0.015950766 & 2.181207 & 4.535328896 \\
\hline AF385327 & MDM2 & $1.93 \mathrm{E}-005$ & 0.015950766 & 1.089126 & 2.127451263 \\
\hline ВС070493 & TOB1 & $1.95 \mathrm{E}-005$ & 0.015950766 & 0.757875 & 1.690997951 \\
\hline NM_015655 & ZNF337 & $2.06 \mathrm{E}-005$ & 0.016199911 & 0.762378 & 1.696284223 \\
\hline CR592601 & HTF9C & $2.06 \mathrm{E}-005$ & 0.016199911 & 0.743771 & 1.674546788 \\
\hline AF370432 & PML & $2.09 \mathrm{E}-005$ & 0.016199911 & 0.459983 & 1.375525262 \\
\hline NM_003172 & SURF1 & $2.12 \mathrm{E}-005$ & 0.016199911 & 0.730661 & 1.659399508 \\
\hline AK125827 & LRRC41 & $2.23 \mathrm{E}-005$ & 0.016736193 & 0.256379 & 1.194477114 \\
\hline ВС002649 & HIST1H1C & $2.33 \mathrm{E}-005$ & 0.01697618 & 1.161077 & 2.236243048 \\
\hline ВC031558 & C1orf183 & $2.37 \mathrm{E}-005$ & 0.01697618 & 1.386175 & 2.613848298 \\
\hline XM_934793 & DENND4B & $2.43 \mathrm{E}-005$ & 0.01697618 & 0.38942 & 1.309866399 \\
\hline ВC007518 & HIST1H3H & $2.44 \mathrm{E}-005$ & 0.01697618 & 1.4268 & 2.688497932 \\
\hline NM_000094 & COL7A1 & $2.45 \mathrm{E}-005$ & 0.01697618 & 1.604835 & 3.041610634 \\
\hline ВС067436 & CYP3A7 & $2.52 \mathrm{E}-005$ & 0.01717885 & 1.596736 & 3.024581609 \\
\hline NM_013956 & NRG1 & $2.64 \mathrm{E}-005$ & 0.017765058 & 2.53177 & 5.782807855 \\
\hline M80185 & PML & $2.69 \mathrm{E}-005$ & 0.017793919 & 0.673749 & 1.595213097 \\
\hline AK001070 & ZNF692 & $2.73 \mathrm{E}-005$ & 0.017793919 & 0.768237 & 1.703186724 \\
\hline ВС041667 & EYA3 & 2.87E-005 & 0.018025584 & -0.54224 & -1.456230612 \\
\hline
\end{tabular}




\begin{tabular}{|c|c|c|c|c|c|}
\hline NM_001025593 & ARFIP1 & $2.89 \mathrm{E}-005$ & 0.018025584 & -0.52497 & -1.43890505 \\
\hline NM_033200 & ВC002942 & $2.90 \mathrm{E}-005$ & 0.018025584 & 0.659475 & 1.579507307 \\
\hline AF064771 & DGKA & $2.95 \mathrm{E}-005$ & 0.018025584 & 0.846342 & 1.797937033 \\
\hline ВC005091 & HERPUD2 & $2.97 \mathrm{E}-005$ & 0.018025584 & -0.47142 & -1.386468691 \\
\hline NM_004628 & XPC & 3.07E-005 & 0.018025584 & 0.828717 & 1.776105322 \\
\hline AF385322 & MDM2 & $3.11 \mathrm{E}-005$ & 0.018025584 & 1.030412 & 2.042608064 \\
\hline ВC003099 & DPH1 & $3.12 \mathrm{E}-005$ & 0.018025584 & 0.707869 & 1.633390081 \\
\hline $\mathrm{BC} 028337$ & GCS1 & $3.15 \mathrm{E}-005$ & 0.018025584 & 0.503381 & 1.417531968 \\
\hline NM_002486 & NCBP1 & $3.16 \mathrm{E}-005$ & 0.018025584 & -0.35423 & -1.2783016 \\
\hline AF385323 & MDM2 & $3.26 \mathrm{E}-005$ & 0.018157822 & 1.279149 & 2.426957431 \\
\hline NM_032324 & C1orf57 & $3.27 \mathrm{E}-005$ & 0.018157822 & 0.66364 & 1.584073802 \\
\hline ВC070314 & MGP & $3.32 \mathrm{E}-005$ & 0.018239392 & -0.77447 & -1.710559503 \\
\hline AK091661 & DCTN3 & $3.45 \mathrm{E}-005$ & 0.018727419 & 0.867575 & 1.824592969 \\
\hline NM_020375 & C12orf5 & $3.51 \mathrm{E}-005$ & 0.018833349 & 1.140114 & 2.203983739 \\
\hline NM_017445 & H2BFS & $3.72 \mathrm{E}-005$ & 0.01972195 & 0.734732 & 1.664087997 \\
\hline ВС019269 & MRPL16 & $3.83 \mathrm{E}-005$ & 0.020044557 & 0.069647 & 1.049460059 \\
\hline NM_001039476 & C16orf35 & $3.88 \mathrm{E}-005$ & 0.020094339 & 0.631713 & 1.54940335 \\
\hline CR605682 & LYPLA2 & $4.02 \mathrm{E}-005$ & 0.020402425 & 0.796434 & 1.736803381 \\
\hline NM_025165 & ELL3 & 4.03E-005 & 0.020402425 & 0.621991 & 1.538997666 \\
\hline AF054506 & SLC12A4 & 4.19E-005 & 0.0206016 & 0.741354 & 1.671743996 \\
\hline NM_182706 & SCRIB & $4.19 \mathrm{E}-005$ & 0.0206016 & 1.133978 & 2.194630675 \\
\hline CR598294 & C1orf66 & $4.21 \mathrm{E}-005$ & 0.0206016 & 0.821877 & 1.767704092 \\
\hline NM_130459 & TOR2A & $4.25 \mathrm{E}-005$ & 0.0206016 & 0.78156 & 1.718989092 \\
\hline AK123386 & unknown & $4.40 \mathrm{E}-005$ & 0.020604536 & 0.837939 & 1.787495266 \\
\hline NM_032885 & ATG4D & 4.45E-005 & 0.020604536 & 0.534127 & 1.448065937 \\
\hline BC062362 & RPUSD3 & $4.45 \mathrm{E}-005$ & 0.020604536 & 0.629028 & 1.546522703 \\
\hline BC110622 & LIG1 & 4.57E-005 & 0.020604536 & 1.233335 & 2.351099013 \\
\hline NM_005632 & SOLH & 4.68E-005 & 0.020604536 & 0.554222 & 1.468376578 \\
\hline NM_005223 & DNASE1 & $4.69 \mathrm{E}-005$ & 0.020604536 & 0.462391 & 1.377823672 \\
\hline NM_024328 & THTPA & $4.70 \mathrm{E}-005$ & 0.020604536 & 0.806855 & 1.749393213 \\
\hline NM_206920 & MAMDC4 & 4.72E-005 & 0.020604536 & 1.063317 & 2.089730133 \\
\hline XM_934621 & LOC284184 & $4.76 \mathrm{E}-005$ & 0.020604536 & 1.02759 & 2.038616432 \\
\hline NM_013301 & HSU79303 & 4.79E-005 & 0.020604536 & 0.726878 & 1.655054002 \\
\hline AF385324 & unknown & $5.10 \mathrm{E}-005$ & 0.020604536 & 1.604606 & 3.041125889 \\
\hline ВC069473 & GGT1 & $5.11 \mathrm{E}-005$ & 0.020604536 & 1.312771 & 2.484181921 \\
\hline AF176921 & unknown & $5.11 \mathrm{E}-005$ & 0.020604536 & 2.886867 & 7.39662435 \\
\hline
\end{tabular}


Continued

\begin{tabular}{|c|c|c|c|c|c|}
\hline NM_145059 & FUK & $5.15 \mathrm{E}-005$ & 0.020604536 & 1.000631 & 2.000874678 \\
\hline NM_017722 & TRMT1 & $5.23 \mathrm{E}-005$ & 0.020604536 & 0.86186 & 1.817380484 \\
\hline XM_930513 & LOC440456 & $5.34 \mathrm{E}-005$ & 0.020604536 & 0.764318 & 1.6985666 \\
\hline ВC039024 & FBXO22 & $5.43 \mathrm{E}-005$ & 0.020604536 & 0.876871 & 1.836388403 \\
\hline BC069418 & CYP3A4 & $5.45 \mathrm{E}-005$ & 0.020604536 & 1.675782 & 3.194925896 \\
\hline NM_015209 & RP1-21O18.1 & $5.51 \mathrm{E}-005$ & 0.020604536 & 0.603114 & 1.518991706 \\
\hline AK127080 & LZTR1 & $5.59 \mathrm{E}-005$ & 0.020604536 & 0.49886 & 1.413096403 \\
\hline NM_012170 & FBXO22 & $5.62 \mathrm{E}-005$ & 0.020604536 & 1.194935 & 2.289345202 \\
\hline NM_022767 & ISG20L1 & $5.64 \mathrm{E}-005$ & 0.020604536 & 0.726529 & 1.654652821 \\
\hline NM_000613 & HPX & $5.64 \mathrm{E}-005$ & 0.020604536 & 1.330857 & 2.515521393 \\
\hline NM_017905 & TMCO3 & $5.68 \mathrm{E}-005$ & 0.020604536 & -0.41016 & -1.328837059 \\
\hline NM_004328 & BCS1L & $5.69 \mathrm{E}-005$ & 0.020604536 & 0.608159 & 1.524312942 \\
\hline NM_007150 & ZNF185 & $5.70 \mathrm{E}-005$ & 0.020604536 & 0.577086 & 1.491833043 \\
\hline AL834398 & LSM14A & $5.72 \mathrm{E}-005$ & 0.020604536 & -0.36327 & -1.2863396 \\
\hline AK055777 & FLYWCH1 & $5.73 \mathrm{E}-005$ & 0.020604536 & 0.544903 & 1.458922371 \\
\hline NM_003869 & CES2 & $5.80 \mathrm{E}-005$ & 0.020604536 & 0.986578 & 1.981479327 \\
\hline NM_003917 & AP1G2 & $5.83 \mathrm{E}-005$ & 0.020604536 & 0.658535 & 1.578478896 \\
\hline AY930112 & DGKA & $5.86 \mathrm{E}-005$ & 0.020604536 & 1.163852 & 2.240548918 \\
\hline NM_006881 & MDM2 & $5.88 \mathrm{E}-005$ & 0.020604536 & 1.408208 & 2.654072044 \\
\hline ВC006523 & SGK2 & $5.92 \mathrm{E}-005$ & 0.020604536 & -1.36108 & -2.568780585 \\
\hline BC002882 & C16orf5 & $5.92 \mathrm{E}-005$ & 0.020604536 & 0.540191 & 1.454165515 \\
\hline NM_000903 & NQO1 & $5.94 \mathrm{E}-005$ & 0.020604536 & -0.59173 & -1.507057308 \\
\hline XM_932518 & LOC644923 & $5.99 \mathrm{E}-005$ & 0.020604536 & -0.3949 & -1.314852061 \\
\hline $\mathrm{BC} 018143$ & $\mathrm{CDC} 34$ & $5.99 \mathrm{E}-005$ & 0.020604536 & 0.453384 & 1.369248658 \\
\hline NM_006225 & PLCD1 & $6.18 \mathrm{E}-005$ & 0.020604536 & 0.906876 & 1.87498064 \\
\hline ВС000491 & PCNA & $6.46 \mathrm{E}-005$ & 0.020604536 & 1.36268 & 2.571625345 \\
\hline NM_018494 & LRDD & $6.47 \mathrm{E}-005$ & 0.020604536 & 2.041902 & 4.11788099 \\
\hline AF319947 & MMS19 & $6.49 \mathrm{E}-005$ & 0.020604536 & 0.422518 & 1.340264634 \\
\hline XM_928241 & LOC643452 & $6.49 \mathrm{E}-005$ & 0.020604536 & -0.51581 & -1.429800129 \\
\hline NM_004480 & FUT8 & $6.49 \mathrm{E}-005$ & 0.020604536 & -0.51548 & -1.42947169 \\
\hline NM_033004 & NALP1 & $6.51 \mathrm{E}-005$ & 0.020604536 & 0.833615 & 1.782145605 \\
\hline XM_933587 & LOC643556 & $6.54 \mathrm{E}-005$ & 0.020604536 & 0.610897 & 1.527208453 \\
\hline NM_003805 & CRADD & $6.55 \mathrm{E}-005$ & 0.020604536 & 0.646205 & 1.56504606 \\
\hline ВС078144 & SULT1A4 & $6.61 \mathrm{E}-005$ & 0.020604536 & 0.707714 & 1.63321418 \\
\hline NM_006019 & TCIRG1 & $6.64 \mathrm{E}-005$ & 0.020604536 & 0.363656 & 1.286682725 \\
\hline NM_033240 & PML & $6.65 \mathrm{E}-005$ & 0.020604536 & 0.531943 & 1.445874775 \\
\hline
\end{tabular}




\begin{tabular}{|c|c|c|c|c|c|}
\hline NM_018676 & THSD1 & $6.67 \mathrm{E}-005$ & 0.020604536 & 1.405445 & 2.648995451 \\
\hline BC104992 & KIAA1033 & $6.81 \mathrm{E}-005$ & 0.020604536 & -0.49818 & -1.412426327 \\
\hline ВC093632 & FAAH & $6.83 \mathrm{E}-005$ & 0.020604536 & 1.1291 & 2.18722269 \\
\hline NM_015169 & RRS1 & $6.92 \mathrm{E}-005$ & 0.020604536 & 0.779009 & 1.715952137 \\
\hline NM_080749 & NEURL2 & $6.94 \mathrm{E}-005$ & 0.020604536 & 1.043313 & 2.060954583 \\
\hline NM_003534 & HIST1H3G & $6.98 \mathrm{E}-005$ & 0.020604536 & 0.773666 & 1.709608644 \\
\hline AY359091 & ARNT & $6.99 \mathrm{E}-005$ & 0.020604536 & -0.49157 & -1.4059694 \\
\hline BC105637 & OGFOD2 & $7.08 \mathrm{E}-005$ & 0.020604536 & 0.88945 & 1.85246971 \\
\hline NM_006536 & CLCA2 & 7.13E-005 & 0.020604536 & 1.987447 & 3.965347424 \\
\hline NM_006880 & MDM2 & $7.25 \mathrm{E}-005$ & 0.020604536 & 1.140287 & 2.204248353 \\
\hline XM_928729 & LOC645719 & $7.26 \mathrm{E}-005$ & 0.020604536 & 0.483691 & 1.3983167 \\
\hline NM_017460 & CYP3A4 & $7.30 \mathrm{E}-005$ & 0.020604536 & 1.646393 & 3.130499695 \\
\hline BC069522 & $\mathrm{RBP} 2$ & $7.33 \mathrm{E}-005$ & 0.020604536 & 1.007376 & 2.010251338 \\
\hline NM_181573 & RFC4 & $7.33 \mathrm{E}-005$ & 0.020604536 & -0.78187 & -1.719360163 \\
\hline NM_006844 & ILVBL & $7.38 \mathrm{E}-005$ & 0.020604536 & 0.376307 & 1.298014812 \\
\hline BC029360 & SUV39H2 & $7.39 \mathrm{E}-005$ & 0.020604536 & -0.58396 & -1.498954432 \\
\hline NM_198576 & AGRN & $7.43 \mathrm{E}-005$ & 0.020604536 & 0.558501 & 1.472738366 \\
\hline NM_001003692 & ZMAT5 & $7.50 \mathrm{E}-005$ & 0.020604536 & 0.83809 & 1.787681974 \\
\hline NM_013959 & NRG1 & $7.52 \mathrm{E}-005$ & 0.020604536 & 2.619473 & 6.145254462 \\
\hline AM180340 & BLNK & $7.54 \mathrm{E}-005$ & 0.020604536 & 2.706194 & 6.525976329 \\
\hline NM_005940 & MMP11 & $7.60 \mathrm{E}-005$ & 0.020604536 & 1.280345 & 2.42897061 \\
\hline NM_000666 & ACY1 & $7.69 \mathrm{E}-005$ & 0.020604536 & 0.649747 & 1.56889254 \\
\hline NM_001007523 & F8A2 & 7.71E-005 & 0.020604536 & 0.696871 & 1.620984908 \\
\hline NM_018209 & ARFGAP1 & 7.72E-005 & 0.020604536 & 0.459677 & 1.37523368 \\
\hline AY444560 & C8orf38 & $7.76 \mathrm{E}-005$ & 0.020604536 & 1.443874 & 2.720504354 \\
\hline AY358149 & THSD1 & $7.79 \mathrm{E}-005$ & 0.020604536 & 1.508763 & 2.845658704 \\
\hline AK000538 & ZNF692 & $7.81 \mathrm{E}-005$ & 0.020604536 & 0.579584 & 1.494418065 \\
\hline BC053670 & FLJ21736 & $7.85 \mathrm{E}-005$ & 0.020604536 & 2.606133 & 6.088692786 \\
\hline $\mathrm{BC} 005272$ & MGP & $7.88 \mathrm{E}-005$ & 0.020604536 & -0.77654 & -1.713013501 \\
\hline ВC009189 & NDUFA13 & $7.91 \mathrm{E}-005$ & 0.020604536 & 0.630508 & 1.548110487 \\
\hline NM_025233 & COASY & 7.97E-005 & 0.020604536 & 0.456961 & 1.372647484 \\
\hline NM_014278 & HSPA4L & $7.98 \mathrm{E}-005$ & 0.020604536 & 1.137377 & 2.199807032 \\
\hline ВC002984 & THTPA & $8.01 \mathrm{E}-005$ & 0.020604536 & 0.619879 & 1.536746559 \\
\hline BC101631 & CYP3A4 & $8.13 \mathrm{E}-005$ & 0.020798939 & 1.773076 & 3.41781858 \\
\hline NM_018244 & C20orf44 & $8.24 \mathrm{E}-005$ & 0.020971002 & 0.781028 & 1.718354723 \\
\hline NM 152277 & DC-UbP & $8.34 \mathrm{E}-005$ & 0.021096576 & -0.53018 & -1.444110612 \\
\hline
\end{tabular}


Continued

\begin{tabular}{|c|c|c|c|c|c|}
\hline NM_139005 & HFE & $8.51 \mathrm{E}-005$ & 0.021123479 & 0.466799 & 1.382040016 \\
\hline CR594512 & FDXR & $8.52 \mathrm{E}-005$ & 0.021123479 & 1.944309 & 3.848535056 \\
\hline AF092844 & MDM2 & $8.56 \mathrm{E}-005$ & 0.021123479 & 1.246143 & 2.372064052 \\
\hline NM_000514 & GDNF & $8.57 \mathrm{E}-005$ & 0.021123479 & 1.841456 & 3.583714249 \\
\hline XM_926697 & FLJ44451 & 8.63E-005 & 0.021123479 & 0.665459 & 1.586072686 \\
\hline NM_001024938 & SLC2A11 & $8.65 \mathrm{E}-005$ & 0.021123479 & 0.691689 & 1.615173505 \\
\hline NM_018161 & NADSYN1 & $8.68 \mathrm{E}-005$ & 0.021123479 & 0.965844 & 1.95320651 \\
\hline NM_022497 & MRPS25 & $8.77 \mathrm{E}-005$ & 0.021214728 & 0.39213 & 1.312329298 \\
\hline NM_194430 & RNASE4 & $8.85 \mathrm{E}-005$ & 0.021214728 & -0.32499 & -1.252658661 \\
\hline NM_152718 & VWCE & $8.86 \mathrm{E}-005$ & 0.021214728 & 3.125943 & 8.729768798 \\
\hline BX647267 & HMGB1 & $9.07 \mathrm{E}-005$ & 0.021395376 & -0.64022 & -1.558566661 \\
\hline BC106879 & STRN & $9.07 \mathrm{E}-005$ & 0.021395376 & -0.58613 & -1.501215357 \\
\hline AM180330 & BLNK & $9.07 \mathrm{E}-005$ & 0.021395376 & 2.739121 & 6.676633227 \\
\hline $\mathrm{BC} 011735$ & PLSCR3 & $9.22 \mathrm{E}-005$ & 0.021617615 & 0.600885 & 1.51664708 \\
\hline NM_006404 & PROCR & $9.34 \mathrm{E}-005$ & 0.021803886 & 0.99811 & 1.997381787 \\
\hline NM_018275 & FLJ10925 & $9.54 \mathrm{E}-005$ & 0.021836594 & 0.768826 & 1.703882289 \\
\hline XM_928682 & LOC645671 & $9.54 \mathrm{E}-005$ & 0.021836594 & -0.55613 & -1.470318841 \\
\hline NM_024531 & GPR172A & $9.54 \mathrm{E}-005$ & 0.021836594 & 0.448516 & 1.364635899 \\
\hline NM_032601 & MCEE & $9.55 \mathrm{E}-005$ & 0.021836594 & 1.075926 & 2.108075068 \\
\hline BC005359 & GMFB & $9.74 \mathrm{E}-005$ & 0.022004015 & -0.35951 & -1.282988834 \\
\hline NM_032038 & SPIN1 & $9.81 \mathrm{E}-005$ & 0.022004015 & 0.467335 & 1.382552939 \\
\hline $\mathrm{BC} 035817$ & FLJ11286 & $9.83 \mathrm{E}-005$ & 0.022004015 & 0.8416 & 1.792036255 \\
\hline NM_175063 & LOC284361 & $9.97 \mathrm{E}-005$ & 0.022004015 & 0.569923 & 1.48444383 \\
\hline NM_003146 & SSRP1 & $1.00 \mathrm{E}-004$ & 0.022004015 & -0.34641 & -1.271390356 \\
\hline NM_000794 & DRD1 & 0.000100151 & 0.022004015 & 1.297878 & 2.45866995 \\
\hline AF258573 & RBED1 & 0.00010043 & 0.022004015 & 0.779479 & 1.71651036 \\
\hline NM_002673 & PLXNB1 & 0.000100515 & 0.022004015 & 1.068407 & 2.097116451 \\
\hline NM_019103 & ZMAT5 & 0.000100656 & 0.022004015 & 0.816691 & 1.761361448 \\
\hline ВC002869 & STXBP2 & 0.000101753 & 0.022136538 & 0.848131 & 1.800166728 \\
\hline ВC013294 & DKFZP564O0823 & 0.000102563 & 0.022205475 & 1.195626 & 2.290441291 \\
\hline XM_929677 & LOC286239 & 0.000103721 & 0.022348661 & -0.83317 & -1.781593484 \\
\hline NM_001120 & TETRAN & 0.000105315 & 0.022584127 & 0.62249 & 1.539529861 \\
\hline NM_005749 & TOB1 & 0.000106266 & 0.022679932 & 0.435847 & 1.352704688 \\
\hline NM_002917 & RFNG & 0.000107727 & 0.022797458 & 0.497059 & 1.411333856 \\
\hline XM_375806 & DENND4B & 0.000108328 & 0.022797458 & 0.446105 & 1.362357412 \\
\hline $\mathrm{BC} 053675$ & TMPO & 0.000108513 & 0.022797458 & -1.69503 & -3.237831441 \\
\hline
\end{tabular}




\begin{tabular}{|c|c|c|c|c|c|}
\hline NM_003562 & SLC25A11 & 0.000109199 & 0.022797458 & 0.490737 & 1.405162277 \\
\hline NM_013314 & BLNK & 0.000109348 & 0.022797458 & 2.921617 & 7.576950496 \\
\hline AK097937 & unknown & 0.000110195 & 0.022868298 & -0.55121 & -1.465310533 \\
\hline NM_001127 & AP1B1 & 0.000111364 & 0.022991949 & 0.789246 & 1.728171284 \\
\hline NM_016462 & TMEM14C & 0.000111812 & 0.022991949 & 0.299215 & 1.230474297 \\
\hline NM_182543 & NSUN6 & 0.000112462 & 0.023020471 & 0.500217 & 1.414426187 \\
\hline NM_030648 & SETD7 & 0.000113028 & 0.02303167 & -0.28057 & -1.214671718 \\
\hline NM_198044 & ZDHHC16 & 0.000114044 & 0.023082388 & 0.320138 & 1.248449664 \\
\hline NM_001657 & AREG & 0.000114302 & 0.023082388 & 1.416703 & 2.669747068 \\
\hline U46461 & DVL1 & 0.000115408 & 0.023139525 & 0.403262 & 1.32249436 \\
\hline AK055216 & QTRT1 & 0.000116011 & 0.023139525 & 0.664524 & 1.585045621 \\
\hline X53280 & BTF3 & 0.00011642 & 0.023139525 & 0.36662 & 1.289328687 \\
\hline NM_014855 & KIAA0415 & 0.000116641 & 0.023139525 & 0.754598 & 1.687161907 \\
\hline AX775899 & unknown & 0.000117789 & 0.023231215 & 0.567198 & 1.481643398 \\
\hline BC104982 & IL12A & 0.000118293 & 0.023231215 & 1.159623 & 2.233990988 \\
\hline NM_000422 & KRT17 & 0.00011865 & 0.023231215 & -0.69737 & -1.621551574 \\
\hline AK055636 & ANTXR2 & 0.000120044 & 0.023283202 & -0.39239 & -1.312570321 \\
\hline ВC033907 & SHC4 & 0.000120661 & 0.023283202 & 1.848102 & 3.600262955 \\
\hline NM_024112 & C9orf16 & 0.000120759 & 0.023283202 & 0.585317 & 1.500368858 \\
\hline ВC058160 & LOC554234 & 0.000120984 & 0.023283202 & -1.00962 & -2.013380045 \\
\hline AK097538 & FLJ21736 & 0.000121598 & 0.023301705 & 2.698498 & 6.491259401 \\
\hline XM_933562 & LOC643556 & 0.000122153 & 0.023308956 & 0.452226 & 1.368149336 \\
\hline NM_013274 & POLL & 0.000124176 & 0.02345206 & 0.582656 & 1.497603411 \\
\hline NM_001009925 & C20orf30 & 0.000124452 & 0.02345206 & 0.354268 & 1.278336452 \\
\hline NM_175841 & SMO & 0.000124695 & 0.02345206 & 0.776625 & 1.713118955 \\
\hline NM_014014 & ASCC3L1 & 0.00012594 & 0.02345206 & 0.486793 & 1.401326211 \\
\hline NM_014267 & C11orf58 & 0.000125968 & 0.02345206 & -0.23582 & -1.177577381 \\
\hline NM_015133 & MAPK8IP3 & 0.000126515 & 0.02345206 & 0.541048 & 1.455028988 \\
\hline NM_003858 & CCNK & 0.000126699 & 0.02345206 & 0.259691 & 1.197222071 \\
\hline NM_022372 & GBL & 0.000127327 & 0.02345206 & 0.384275 & 1.305203284 \\
\hline NM_015949 & C7orf20 & 0.00012759 & 0.02345206 & 0.719948 & 1.647123179 \\
\hline NM_003946 & NOL3 & 0.000128894 & 0.02352597 & 0.763178 & 1.697224864 \\
\hline ВC012362 & RAP2B & 0.000129037 & 0.02352597 & 0.843525 & 1.7944289 \\
\hline NM_006396 & SSSCA1 & 0.000130792 & 0.023749891 & 0.581673 & 1.496583596 \\
\hline $\mathrm{BC} 047881$ & FAM8A1 & 0.000134324 & 0.024293183 & -0.63622 & -1.554255431 \\
\hline ВC022276 & CPM & 0.000135709 & 0.024319547 & 1.734674 & 3.328041804 \\
\hline
\end{tabular}




\section{Continued}

\begin{tabular}{|c|c|c|c|c|c|}
\hline NM_012075 & C16orf35 & 0.000136684 & 0.024319547 & 0.634592 & 1.552498833 \\
\hline NM_024927 & PLEKHH3 & 0.000137188 & 0.024319547 & 0.96858 & 1.956912925 \\
\hline NM_005834 & TIMM17B & 0.000137441 & 0.024319547 & 0.709074 & 1.634754262 \\
\hline NM_015679 & TRUB2 & 0.000137511 & 0.024319547 & 0.50177 & 1.415949904 \\
\hline ВC065235 & SPIN1 & 0.000137864 & 0.024319547 & 0.330978 & 1.257866109 \\
\hline NM_207329 & MYADML & 0.00013825 & 0.024319547 & -0.40323 & -1.322464391 \\
\hline NM_017865 & ZNF692 & 0.000140582 & 0.02463352 & 0.890252 & 1.853499829 \\
\hline ВC013116 & CLIPR-59 & 0.000143743 & 0.025038337 & 0.458221 & 1.373846884 \\
\hline NM_031957 & KRTAP1-5 & 0.00014464 & 0.025038337 & 1.160349 & 2.235115291 \\
\hline NM_004148 & NINJ1 & 0.00014472 & 0.025038337 & 0.928226 & 1.902933983 \\
\hline NM_024741 & ZNF408 & 0.000145116 & 0.025038337 & 0.606996 & 1.523084531 \\
\hline XM_933610 & LOC643556 & 0.000150267 & 0.025631098 & 0.78141 & 1.718810229 \\
\hline NM_032326 & MGC4618 & 0.000150727 & 0.025631098 & 0.52004 & 1.433994804 \\
\hline NM_022749 & RAI16 & 0.000151485 & 0.025631098 & 0.702885 & 1.627756994 \\
\hline BC112920 & HSPA8 & 0.000151565 & 0.025631098 & -0.23666 & -1.178260308 \\
\hline NM_001002843 & SUHW4 & 0.000152012 & 0.025631098 & -0.24981 & -1.189051217 \\
\hline ВC006567 & SYMPK & 0.000152346 & 0.025631098 & 0.341263 & 1.266864828 \\
\hline NM_005526 & HSF1 & 0.000152536 & 0.025631098 & 0.536363 & 1.450311334 \\
\hline NM_001009812 & LBX2 & 0.000155647 & 0.026056749 & 0.562814 & 1.477147166 \\
\hline NM_004864 & GDF15 & 0.000157544 & 0.026242679 & 1.928 & 3.805272285 \\
\hline NM_024661 & CCDC51 & 0.000159507 & 0.026242679 & 1.098491 & 2.141306089 \\
\hline NM_175840 & SMO & 0.000159737 & 0.026242679 & 0.643258 & 1.561851966 \\
\hline XM_930679 & RP11-144G6.7 & 0.000160465 & 0.026242679 & 0.61926 & 1.536087253 \\
\hline ВC000653 & DNPEP & 0.000160559 & 0.026242679 & 0.274029 & 1.209180082 \\
\hline NM_004377 & CPT1B & 0.000161008 & 0.026242679 & 1.008058 & 2.011202224 \\
\hline NM_177938 & PH-4 & 0.000161173 & 0.026242679 & 0.523886 & 1.437823097 \\
\hline NM_002337 & LRPAP1 & 0.00016142 & 0.026242679 & 0.642737 & 1.561288503 \\
\hline AF201370 & MDM2 & 0.000162009 & 0.026243671 & 1.242205 & 2.365597313 \\
\hline BC112054 & VARSL & 0.000163921 & 0.026401856 & 0.476734 & 1.391590266 \\
\hline NM_080593 & HIST1H2BK & 0.000164158 & 0.026401856 & 1.408705 & 2.654987956 \\
\hline AK092491 & unknown & 0.000165057 & 0.026451984 & 0.591021 & 1.506312004 \\
\hline ВС069757 & PRO1768 & 0.000165746 & 0.026468295 & 0.903213 & 1.870227053 \\
\hline NM_004073 & PLK3 & 0.000167437 & 0.026643797 & 1.019965 & 2.027869531 \\
\hline NM_001033053 & NALP1 & 0.000169306 & 0.026846387 & 0.795635 & 1.735840854 \\
\hline NM_016535 & ZNF581 & 0.000170936 & 0.026945444 & 0.339112 & 1.264977525 \\
\hline NM_181493 & ITPA & 0.000171744 & 0.026945444 & 0.530141 & 1.444070164 \\
\hline
\end{tabular}




\begin{tabular}{|c|c|c|c|c|c|}
\hline AK056120 & CCNL2 & 0.00017175 & 0.026945444 & 0.621656 & 1.538639833 \\
\hline XM_211367 & LOC284184 & 0.000172581 & 0.026945444 & 1.006507 & 2.009040442 \\
\hline NM_001146 & ANGPT1 & 0.000172923 & 0.026945444 & -0.48271 & -1.39736319 \\
\hline NM_031232 & NECAB3 & 0.000175342 & 0.027228157 & 0.974428 & 1.964862444 \\
\hline NM_032621 & BEX2 & 0.000176565 & 0.027323873 & 0.913273 & 1.883313264 \\
\hline ВС002359 & TSN & 0.000177905 & 0.027436973 & -0.17092 & -1.125773416 \\
\hline BC032244 & REXO1 & 0.000179497 & 0.027445671 & 0.588425 & 1.503604011 \\
\hline NM_175047 & PILRB & 0.000179534 & 0.027445671 & 0.586563 & 1.501664658 \\
\hline BC070035 & NR1D2 & 0.000179839 & 0.027445671 & -0.65656 & -1.576323788 \\
\hline NM_016826 & OGG1 & 0.000180399 & 0.027445671 & 0.509329 & 1.423387779 \\
\hline NM_001004426 & PLA2G6 & 0.000182006 & 0.027493944 & 1.292141 & 2.448912101 \\
\hline NM_001376 & DYNC1H1 & 0.000182718 & 0.027493944 & 0.579959 & 1.494806357 \\
\hline NM_198850 & PHLDB3 & 0.000183038 & 0.027493944 & 1.312085 & 2.483000613 \\
\hline BC035214 & SRPK2 & 0.00018384 & 0.027493944 & -0.33381 & -1.260334799 \\
\hline NM_001010915 & PTPLAD2 & 0.000184367 & 0.027493944 & -0.70564 & -1.630870668 \\
\hline NM_001001824 & OR2T27 & 0.000185297 & 0.027493944 & -0.50226 & -1.416426308 \\
\hline BC063785 & PGBD2 & 0.000185833 & 0.027493944 & 0.789353 & 1.728298857 \\
\hline NM_018467 & MDS032 & 0.000186501 & 0.027493944 & 0.423527 & 1.341202599 \\
\hline NM_031472 & TRPT1 & 0.000187663 & 0.027493944 & 0.836842 & 1.786135753 \\
\hline AJ278977 & MDM2 & 0.000188358 & 0.027493944 & 1.583683 & 2.997339642 \\
\hline AK000938 & ZNF691 & 0.000188929 & 0.027493944 & 0.51907 & 1.433031363 \\
\hline NM_004567 & PFKFB4 & 0.00018918 & 0.027493944 & 1.213481 & 2.318964224 \\
\hline NM_004699 & FAM50A & 0.000189284 & 0.027493944 & 0.560794 & 1.475080667 \\
\hline NM_003522 & HIST1H2BF & 0.000189863 & 0.027493944 & 0.761616 & 1.695388163 \\
\hline BC031077 & GRIN2C & 0.000189874 & 0.027493944 & 1.273981 & 2.418278908 \\
\hline BC064570 & C11orf31 & 0.000191739 & 0.027583135 & 0.677328 & 1.599174971 \\
\hline NM_153335 & LYK5 & 0.000192279 & 0.027583135 & 0.666599 & 1.587326787 \\
\hline NM_147184 & TP53I3 & 0.000192629 & 0.027583135 & 1.059109 & 2.083644115 \\
\hline ВC038094 & IFT20 & 0.000194391 & 0.027583135 & 0.413852 & 1.332237719 \\
\hline NM_145036 & $\mathrm{CCDC} 46$ & 0.000194889 & 0.027583135 & -0.70213 & -1.626904814 \\
\hline NM_000254 & MTR & 0.000195442 & 0.027583135 & -0.20971 & -1.156458238 \\
\hline NM_001033551 & TOM1L2 & 0.000195803 & 0.027583135 & 0.53162 & 1.445551101 \\
\hline ВС069119 & GDNF & 0.000197027 & 0.027583135 & 1.773429 & 3.418655826 \\
\hline AK127093 & DGKA & 0.000197158 & 0.027583135 & 1.105381 & 2.151557067 \\
\hline NM_198061 & CES2 & 0.000197303 & 0.027583135 & 0.917607 & 1.888979962 \\
\hline ВC069753 & RFPL3 & 0.000197628 & 0.027583135 & 0.796727 & 1.737155061 \\
\hline
\end{tabular}




\begin{tabular}{|c|c|c|c|c|c|}
\hline BC065741 & RPUSD3 & 0.000197841 & 0.027583135 & 0.719335 & 1.646423204 \\
\hline NM_207013 & TCEB2 & 0.000199815 & 0.027772422 & 0.41621 & 1.334417611 \\
\hline NM_005343 & HRAS & 0.000202496 & 0.02805564 & 0.952672 & 1.935454573 \\
\hline AL136869 & RECQL5 & 0.000203389 & 0.02805564 & 0.788046 & 1.726734645 \\
\hline NM_024417 & FDXR & 0.000203722 & 0.02805564 & 1.976774 & 3.936118473 \\
\hline ВC001573 & LOC134147 & 0.000204697 & 0.028104091 & 0.62485 & 1.542051006 \\
\hline NM_006693 & CPSF4 & 0.000205537 & 0.028133633 & 0.753082 & 1.685388912 \\
\hline NM_030974 & SHARPIN & 0.000206902 & 0.028234534 & 0.542625 & 1.456620032 \\
\hline ВC008962 & GDF15 & 0.000209322 & 0.028330161 & 1.922825 & 3.791647032 \\
\hline AK090418 & LOC349196 & 0.000209381 & 0.028330161 & -0.68897 & -1.612130327 \\
\hline XM_933916 & GPR108 & 0.00020949 & 0.028330161 & 0.412805 & 1.331271862 \\
\hline AK123115 & NAT9 & 0.000211405 & 0.028405248 & 0.62965 & 1.547189857 \\
\hline BC000417 & SMUG1 & 0.000213217 & 0.028405248 & 0.668187 & 1.589074761 \\
\hline NM_001039492 & FHL2 & 0.00021421 & 0.028405248 & 0.773943 & 1.709936952 \\
\hline AK223604 & CYFIP2 & 0.000214732 & 0.028405248 & 3.177553 & 9.047709169 \\
\hline NM_022772 & EPS8L2 & 0.000214836 & 0.028405248 & 1.154149 & 2.225530768 \\
\hline NM_006899 & IDH3B & 0.000214892 & 0.028405248 & 0.504906 & 1.419030684 \\
\hline ВC029796 & LOC116349 & 0.000215027 & 0.028405248 & 1.14759 & 2.215434966 \\
\hline NM_005824 & LRRC17 & 0.000215091 & 0.028405248 & -0.39195 & -1.312168817 \\
\hline BC106720 & HIST1H2BO & 0.000216316 & 0.028483475 & 0.693951 & 1.617708004 \\
\hline NM_016448 & DTL & 0.000217429 & 0.028546628 & -2.31246 & -4.967286515 \\
\hline NM_001283 & AP1S1 & 0.000219159 & 0.02859037 & 0.736157 & 1.665732546 \\
\hline NM_004060 & CCNG1 & 0.000219566 & 0.02859037 & 0.241311 & 1.182066624 \\
\hline NM_005704 & PTPRU & 0.000220214 & 0.02859037 & 0.825715 & 1.772413442 \\
\hline CR610028 & ZDHHC16 & 0.000220302 & 0.02859037 & 0.325452 & 1.253056768 \\
\hline NM_022156 & DUS1L & 0.000222748 & 0.0286294 & 0.460923 & 1.37642211 \\
\hline NM_014186 & COMMD9 & 0.000223284 & 0.0286294 & 0.628971 & 1.546461825 \\
\hline NM_152464 & C17orf32 & 0.000223518 & 0.0286294 & 0.55106 & 1.465162034 \\
\hline AB102799 & unknown & 0.000223675 & 0.0286294 & -0.38602 & -1.306780982 \\
\hline NM_014226 & RAGE & 0.000223781 & 0.0286294 & 0.706431 & 1.631762309 \\
\hline NM_000765 & CYP3A7 & 0.000225072 & 0.028712956 & 1.666446 & 3.174316309 \\
\hline NM_001039675 & UNC45A & 0.000227659 & 0.028960937 & 0.381496 & 1.302692019 \\
\hline ВC029882 & CART & 0.000228537 & 0.028990748 & -0.47724 & -1.392077141 \\
\hline NM_000481 & AMT & 0.000230169 & 0.029023322 & 0.548327 & 1.462389039 \\
\hline NM_004881 & ТР53I3 & 0.000230946 & 0.029023322 & 1.106592 & 2.153364416 \\
\hline XM_929276 & LOC646342 & 0.000232092 & 0.029023322 & -1.34154 & -2.534214705 \\
\hline
\end{tabular}




\begin{tabular}{|c|c|c|c|c|c|}
\hline U33203 & MDM2 & 0.000232208 & 0.029023322 & 1.171052 & 2.251758686 \\
\hline NM_001035506 & FLJ21839 & 0.000232426 & 0.029023322 & 0.556005 & 1.470192554 \\
\hline NM_001834 & CLTB & 0.000234853 & 0.029159542 & 0.313156 & 1.242422257 \\
\hline NM_005319 & HIST1H1C & 0.000235422 & 0.029159542 & 1.225939 & 2.339076533 \\
\hline ВC050345 & SEPT10 & 0.000235835 & 0.029159542 & -0.41262 & -1.331102002 \\
\hline BC105791 & C20orf44 & 0.000236908 & 0.029159542 & 0.754831 & 1.68743381 \\
\hline BC000154 & SLC12A9 & 0.000237272 & 0.029159542 & 0.543844 & 1.45785213 \\
\hline NM_004809 & STOML1 & 0.000237638 & 0.029159542 & 0.616827 & 1.53349915 \\
\hline NM_022116 & FIGNL1 & 0.000244442 & 0.02983187 & -0.79284 & -1.732480111 \\
\hline ВC036742 & PLA2G6 & 0.000250372 & 0.030472932 & 1.108781 & 2.156633383 \\
\hline ВC006152 & ASPSCR1 & 0.000251285 & 0.030501655 & 0.349574 & 1.274183987 \\
\hline NM_018838 & NDUFA12 & 0.000254539 & 0.030770071 & 0.218751 & 1.163725942 \\
\hline NM_006306 & SMC1L1 & 0.000255217 & 0.030770071 & -0.66316 & -1.583550165 \\
\hline NM_145183 & PYCARD & 0.000256379 & 0.030770071 & 0.533324 & 1.447260005 \\
\hline $\mathrm{BC} 035576$ & MAP3K14 & 0.000256524 & 0.030770071 & 0.491708 & 1.406108487 \\
\hline NM_030751 & ZEB1 & 0.000256913 & 0.030770071 & -0.45281 & -1.368707647 \\
\hline NM_207344 & SPRYD4 & 0.000258127 & 0.030833545 & 0.524439 & 1.438373851 \\
\hline NM_017495 & RNPC1 & 0.000262586 & 0.03120059 & 0.733735 & 1.662938373 \\
\hline NM_024623 & OGFOD2 & 0.000263909 & 0.031275326 & 0.745877 & 1.676993137 \\
\hline AB037861 & INTS1 & 0.000266398 & 0.031375578 & 0.444582 & 1.360919653 \\
\hline NM_006591 & POLD3 & 0.000266734 & 0.031375578 & -0.57512 & -1.489796667 \\
\hline ВC032095 & CES2 & 0.000266845 & 0.031375578 & 0.790558 & 1.729742948 \\
\hline NM_203437 & AFTIPHILIN & 0.000270841 & 0.031762474 & 0.800571 & 1.741790599 \\
\hline NM_005611 & RBL2 & 0.000273561 & 0.031998156 & -0.63408 & -1.551943397 \\
\hline NM_012423 & RPL13A & 0.000274644 & 0.032041546 & 0.216508 & 1.161917881 \\
\hline AK090774 & PLCD1 & 0.000278061 & 0.03229583 & 0.814386 & 1.758550007 \\
\hline NM_014853 & RUTBC1 & 0.000278258 & 0.03229583 & 0.620561 & 1.537472941 \\
\hline CR595121 & ZNF692 & 0.000279733 & 0.032340087 & 0.670359 & 1.591469142 \\
\hline CR606194 & unknown & 0.000280488 & 0.032340087 & 0.707067 & 1.632481836 \\
\hline ВC093622 & BLM & 0.000280794 & 0.032340087 & -2.38397 & -5.219694079 \\
\hline NM_012135 & FAM50B & 0.000283927 & 0.032602086 & -0.59321 & -1.508594915 \\
\hline ВС041692 & ACSL3 & 0.000284786 & 0.032602086 & -0.61671 & -1.533372395 \\
\hline ВC067898 & ZDHHC20 & 0.00028524 & 0.032602086 & -0.58069 & -1.49556317 \\
\hline
\end{tabular}




\section{Continued}

\begin{tabular}{|c|c|c|c|c|c|}
\hline NM_004125 & LOC552891 & 0.000287751 & 0.032663206 & 0.569796 & 1.484313935 \\
\hline NM_058004 & PIK4CA & 0.000288373 & 0.032663206 & 0.581922 & 1.496842174 \\
\hline AK127235 & FLYWCH1 & 0.000288393 & 0.032663206 & 0.549769 & 1.463850874 \\
\hline $\mathrm{BC} 066553$ & C6orf114 & 0.000288676 & 0.032663206 & -0.39632 & -1.316145963 \\
\hline ВC080636 & EPS8L2 & 0.000291314 & 0.032801406 & 1.15071 & 2.220231173 \\
\hline NM_199234 & GDNF & 0.000291705 & 0.032801406 & 2.336181 & 5.049642771 \\
\hline NM_173161 & IL1F10 & 0.000292083 & 0.032801406 & 0.342449 & 1.267906873 \\
\hline NM_000107 & DDB2 & 0.000292954 & 0.032817448 & 1.361112 & 2.568831693 \\
\hline NM_003969 & UBE2M & 0.000295824 & 0.033056648 & 0.214702 & 1.160464083 \\
\hline NM_014956 & CEP164 & 0.000300126 & 0.033446965 & 0.766103 & 1.700669186 \\
\hline AY358250 & SHC4 & 0.000300911 & 0.033446965 & 1.537039 & 2.901982678 \\
\hline NM_001037633 & SIL1 & 0.00030182 & 0.033446965 & 0.510697 & 1.424737934 \\
\hline AF289556 & unknown & 0.000302288 & 0.033446965 & -0.4752 & -1.390107465 \\
\hline NM_016821 & OGG1 & 0.000306048 & 0.033717588 & 1.116248 & 2.16782479 \\
\hline NM_017750 & RetSat & 0.00030691 & 0.033717588 & 0.585687 & 1.500753354 \\
\hline NM_001037332 & CYFIP2 & 0.00030698 & 0.033717588 & 2.244177 & 4.737668883 \\
\hline NM_001005920 & LOC339123 & 0.000309198 & 0.033833427 & 0.369975 & 1.292330793 \\
\hline XM_932685 & LOC653257 & 0.000309537 & 0.033833427 & 1.254491 & 2.385830228 \\
\hline NM_005101 & ISG15 & 0.000311192 & 0.033931982 & 0.528482 & 1.442410374 \\
\hline ВС000902 & LOC51035 & 0.000312751 & 0.034019647 & 0.453639 & 1.369489851 \\
\hline AB000409 & MKNK1 & 0.000314983 & 0.03417983 & 0.468028 & 1.3832179 \\
\hline NM_002555 & SLC22A18 & 0.000316186 & 0.034227854 & 0.655054 & 1.574674833 \\
\hline XM_378223 & RP11-144G6.7 & 0.000319826 & 0.03448507 & 0.692693 & 1.616297445 \\
\hline NM_017547 & FOXRED1 & 0.000320093 & 0.03448507 & 0.958495 & 1.943282204 \\
\hline NM_001008658 & TUBGCP6 & 0.000321983 & 0.034605824 & 0.787161 & 1.72567557 \\
\hline NM_032867 & MICALCL & 0.000322788 & 0.034609766 & 0.834278 & 1.782964584 \\
\hline ВC004225 & NAT9 & 0.000325171 & 0.034782474 & 0.478233 & 1.393036858 \\
\hline NM_005262 & GFER & 0.000327341 & 0.034931651 & 0.642039 & 1.560533448 \\
\hline NM_006221 & PIN1 & 0.000329519 & 0.035011877 & 0.459173 & 1.374753776 \\
\hline NM_007188 & ABCB8 & 0.000330308 & 0.035011877 & 0.854056 & 1.807575422 \\
\hline $\mathrm{BC} 100808$ & SLC2A11 & 0.000332004 & 0.035011877 & 1.12017 & 2.173725869 \\
\hline NM_024028 & MGC3265 & 0.000332425 & 0.035011877 & 0.776621 & 1.713113982 \\
\hline NM_145804 & АBTB2 & 0.000332811 & 0.035011877 & 1.178724 & 2.263764586 \\
\hline NM_001054 & SULT1A2 & 0.000333139 & 0.035011877 & 0.4522 & 1.368125328 \\
\hline NM_020246 & SLC12A9 & 0.000333654 & 0.035011877 & 0.691581 & 1.615052801 \\
\hline $\mathrm{BC} 011895$ & COQ4 & 0.000334313 & 0.035011877 & 0.873778 & 1.832455715 \\
\hline
\end{tabular}




\begin{tabular}{|c|c|c|c|c|c|}
\hline XM_928494 & LOC645463 & 0.000337968 & 0.035243929 & -0.6093 & -1.525516392 \\
\hline AK000346 & NFYC & 0.000338128 & 0.035243929 & 0.395006 & 1.314948582 \\
\hline ВC000995 & SFN & 0.000338876 & 0.035243929 & 1.133907 & 2.194522783 \\
\hline NM_007245 & ATXN2L & 0.000341202 & 0.035404018 & 0.44118 & 1.35771461 \\
\hline NM_015654 & NAT9 & 0.000343057 & 0.035425893 & 0.653522 & 1.573003434 \\
\hline M97190 & SP2 & 0.000343098 & 0.035425893 & 0.421224 & 1.339063212 \\
\hline NM_019099 & C1orf183 & 0.000343773 & 0.035425893 & 1.859789 & 3.629546054 \\
\hline NM_176826 & ILVBL & 0.000346356 & 0.035593942 & 0.638558 & 1.556771878 \\
\hline AK002100 & PHCA & 0.000346984 & 0.035593942 & -0.67345 & -1.594886159 \\
\hline NM_206538 & LOC284361 & 0.000348836 & 0.035610637 & 0.677604 & 1.599480637 \\
\hline XM_926234 & LOC642832 & 0.000349136 & 0.035610637 & 2.801435 & 6.971336226 \\
\hline NM_005224 & ARID3A & 0.000349573 & 0.035610637 & 0.738044 & 1.667912826 \\
\hline ВC017296 & SESN3 & 0.00035043 & 0.035610637 & -0.64667 & -1.565545927 \\
\hline NM_183010 & TNRC5 & 0.000351314 & 0.035610637 & 0.557644 & 1.471863928 \\
\hline BC112240 & NEK8 & 0.000351892 & 0.035610637 & 0.755989 & 1.68878919 \\
\hline NM_005028 & PIP5K2A & 0.000353302 & 0.035673222 & -0.51575 & -1.429738976 \\
\hline NM_019057 & FLJ10404 & 0.000354735 & 0.035737732 & 0.299024 & 1.230311471 \\
\hline ВC067895 & unknown & 0.000356722 & 0.035827149 & 0.760347 & 1.693897859 \\
\hline $\mathrm{BC} 037542$ & MIB2 & 0.000357213 & 0.035827149 & 1.042387 & 2.059632378 \\
\hline AF318352 & SCRIB & 0.000360145 & 0.036040916 & 1.322689 & 2.501318626 \\
\hline AK131264 & ZNF184 & 0.000361971 & 0.036143343 & -0.42906 & -1.346358283 \\
\hline NM_005072 & SLC12A4 & 0.000364395 & 0.036304905 & 0.587911 & 1.503068511 \\
\hline $\mathrm{BC} 016480$ & PPM1D & 0.000365857 & 0.036370105 & 0.663197 & 1.583587673 \\
\hline NM_001098 & $\mathrm{ACO} 2$ & 0.000367039 & 0.036407216 & 0.582543 & 1.497486847 \\
\hline $\mathrm{BC} 002355$ & HNRNPA1 & 0.000369897 & 0.03661 & -0.40463 & -1.323747314 \\
\hline NM_030807 & SLC2A11 & 0.000373583 & 0.036893753 & 0.790317 & 1.72945384 \\
\hline NM_002624 & PFDN5 & 0.000375613 & 0.037013106 & 0.454234 & 1.370055507 \\
\hline NM_015106 & RAD54L2 & 0.000378885 & 0.037046217 & 0.529344 & 1.443273233 \\
\hline $\mathrm{BC} 005402$ & UCRC & 0.000379806 & 0.037046217 & 0.407152 & 1.326065024 \\
\hline $\mathrm{BC} 020586$ & SFRS14 & 0.000381952 & 0.037046217 & 0.382491 & 1.303591177 \\
\hline NM_181775 & PLXNA4B & 0.000382734 & 0.037046217 & -0.91692 & -1.888078766 \\
\hline NM_145752 & CDIPT & 0.00038475 & 0.037046217 & 0.213113 & 1.159186657 \\
\hline ВС008041 & CPSF3L & 0.000384919 & 0.037046217 & 0.78296 & 1.720657928 \\
\hline $\mathrm{BC} 074737$ & NEURL2 & 0.000384938 & 0.037046217 & 0.869833 & 1.827451531 \\
\hline NM_001735 & $\mathrm{C} 5$ & 0.000385212 & 0.037046217 & -0.54227 & -1.456259309 \\
\hline BC112036 & SESN1 & 0.000385582 & 0.037046217 & 0.927843 & 1.902430011 \\
\hline
\end{tabular}


Continued

\begin{tabular}{|c|c|c|c|c|c|}
\hline $\mathrm{BC} 112271$ & KIF7 & 0.000386563 & 0.037046217 & 0.423367 & 1.341053551 \\
\hline NM_004705 & PRKRIR & 0.000387168 & 0.037046217 & -0.43051 & -1.347713676 \\
\hline NM_005811 & GDF11 & 0.000387397 & 0.037046217 & 0.491275 & 1.405686494 \\
\hline ВС006821 & CBX5 & 0.000387718 & 0.037046217 & -0.8314 & -1.779408002 \\
\hline NM_018518 & MCM10 & 0.000387731 & 0.037046217 & -1.11931 & -2.172436272 \\
\hline ВC072681 & ZA20D1 & 0.00038849 & 0.037046217 & -0.37656 & -1.298244539 \\
\hline NM_172208 & TAPBP & 0.000389112 & 0.037046217 & 0.371858 & 1.294018284 \\
\hline ВC016965 & NALP1 & 0.000391298 & 0.037175754 & 0.622137 & 1.539153399 \\
\hline AF119833 & PFTK1 & 0.000393602 & 0.037315912 & -0.61391 & -1.530403638 \\
\hline ВС029832 & ZYG11B & 0.000394649 & 0.037336601 & -0.40264 & -1.321925631 \\
\hline BC006085 & ARFGAP1 & 0.000395657 & 0.03735347 & 0.501176 & 1.415366932 \\
\hline NM_006828 & $\mathrm{ASCC} 3$ & 0.000399476 & 0.03759174 & 0.762191 & 1.696064548 \\
\hline NM_003523 & HIST1H2BE & 0.00039985 & 0.03759174 & 0.694035 & 1.617802154 \\
\hline NM_014595 & NT5C & 0.000401455 & 0.037629454 & 0.406239 & 1.325226624 \\
\hline XM_932195 & LOC643009 & 0.000401922 & 0.037629454 & 1.417885 & 2.671935638 \\
\hline NM_005708 & GPC6 & 0.00040296 & 0.037648318 & -0.54018 & -1.454152886 \\
\hline NM_032307 & C9orf64 & 0.000405457 & 0.037803195 & -0.48593 & -1.400492657 \\
\hline XM_932681 & LOC653257 & 0.000410478 & 0.038192227 & 1.154277 & 2.225727344 \\
\hline NM_005275 & GNL1 & 0.00041168 & 0.038225153 & 0.339328 & 1.265167058 \\
\hline NM_003422 & MZF1 & 0.00041395 & 0.038280175 & 0.625641 & 1.542895806 \\
\hline CR603836 & NECAB3 & 0.000413973 & 0.038280175 & 0.848887 & 1.801111148 \\
\hline NM_006528 & TFPI2 & 0.000415782 & 0.038317879 & 0.538901 & 1.452865079 \\
\hline NM_148936 & NSUN5C & 0.000416082 & 0.038317879 & 0.66244 & 1.582757005 \\
\hline NM_002488 & NDUFA2 & 0.000420786 & 0.038671971 & 0.66155 & 1.581781201 \\
\hline AK127078 & unknown & 0.000421693 & 0.038676392 & 0.457317 & 1.372985729 \\
\hline NM_138761 & BAX & 0.000423442 & 0.038757835 & 0.671702 & 1.59295118 \\
\hline ВC066952 & NEFL & 0.000425486 & 0.038817021 & 1.196854 & 2.292391985 \\
\hline $\mathrm{BC} 022483$ & ARHGAP29 & 0.000426312 & 0.038817021 & -0.58768 & -1.502825756 \\
\hline ВC026066 & $\mathrm{ASCC} 3$ & 0.000429227 & 0.038817021 & 0.370185 & 1.29251859 \\
\hline NM_138644 & CABYR & 0.000429394 & 0.038817021 & 0.529255 & 1.443183614 \\
\hline NM_015382 & HECTD1 & 0.000429588 & 0.038817021 & -0.1033 & -1.074230028 \\
\hline NM_080916 & DGUOK & 0.000430517 & 0.038817021 & 0.479929 & 1.394674573 \\
\hline ВС017379 & HIST1H2AC & 0.000431396 & 0.038817021 & 0.943462 & 1.923137625 \\
\hline NM_022064 & RNF123 & 0.000431692 & 0.038817021 & 0.643427 & 1.562035439 \\
\hline ВC047118 & MGC13114 & 0.000431846 & 0.038817021 & 0.682263 & 1.604654629 \\
\hline CR612107 & TUSC4 & 0.000434127 & 0.038944317 & 0.624511 & 1.541688603 \\
\hline
\end{tabular}




\begin{tabular}{|c|c|c|c|c|c|}
\hline NM_019884 & GSK3A & 0.000435021 & 0.038946913 & 0.394097 & 1.31411962 \\
\hline NM_014922 & NALP1 & 0.000441654 & 0.039462292 & 0.629958 & 1.547519526 \\
\hline NM_001010883 & FAM102B & 0.000443307 & 0.039467272 & -0.53097 & -1.444896798 \\
\hline AF258572 & GSDML & 0.000443846 & 0.039467272 & 0.500293 & 1.414500324 \\
\hline XM_929819 & LOC646861 & 0.000444822 & 0.039467272 & -1.05102 & -2.071991092 \\
\hline NM_203288 & RP9 & 0.000445215 & 0.039467272 & 0.4274 & 1.344807868 \\
\hline AK125455 & ZNF337 & 0.000446625 & 0.039504248 & 0.739711 & 1.669840787 \\
\hline NM_014699 & ZNF646 & 0.0004476 & 0.039504248 & 0.629384 & 1.546904698 \\
\hline NM_030645 & SH3BP5L & 0.000448264 & 0.039504248 & 0.754456 & 1.686995688 \\
\hline NM_004581 & RABGGTA & 0.000451259 & 0.039690493 & 0.810738 & 1.75410845 \\
\hline ВС074979 & DRD1 & 0.000452229 & 0.039698293 & 1.306172 & 2.472844797 \\
\hline NM_002719 & PPP2R5C & 0.00045425 & 0.039798096 & -0.46495 & -1.380270296 \\
\hline AK074112 & CCNL2 & 0.000461899 & 0.040382561 & 0.523248 & 1.437187635 \\
\hline NM_001003689 & L3MBTL2 & 0.000462714 & 0.040382561 & 0.704667 & 1.629768084 \\
\hline NM_005273 & GNB2 & 0.000464199 & 0.04039402 & 0.54869 & 1.462756695 \\
\hline XM_933425 & LOC653319 & 0.000464639 & 0.04039402 & 0.549828 & 1.463910651 \\
\hline AK126163 & ARHGAP30 & 0.000470269 & 0.040779788 & 0.95674 & 1.940919473 \\
\hline NM_001191 & BCL2L1 & 0.000471659 & 0.040779788 & 1.236457 & 2.356191072 \\
\hline NM_181745 & GPR120 & 0.000471793 & 0.040779788 & -0.56003 & -1.474302679 \\
\hline NM_031209 & QTRT1 & 0.000474274 & 0.040885399 & 0.526729 & 1.440659555 \\
\hline NM_003717 & NPFF & 0.000474831 & 0.040885399 & 0.756762 & 1.689694021 \\
\hline NM_019001 & XRN1 & 0.000476599 & 0.040959305 & -0.33327 & -1.259867696 \\
\hline NM_001002245 & ANAPC11 & 0.000478765 & 0.041027328 & 0.622674 & 1.539726645 \\
\hline ВС037236 & DUSP6 & 0.000479212 & 0.041027328 & 0.550383 & 1.464474844 \\
\hline NM_133175 & APBB3 & 0.000480821 & 0.041086888 & 0.870727 & 1.828584152 \\
\hline NM_001037811 & HSD17B10 & 0.000484076 & 0.041228893 & 0.310014 & 1.239720113 \\
\hline ВС008692 & PTPN11 & 0.000484883 & 0.041228893 & -0.33927 & -1.265112308 \\
\hline NM_006340 & BAIAP2 & 0.000485229 & 0.041228893 & 0.364064 & 1.287045913 \\
\hline NM_020317 & C1orf63 & 0.000488178 & 0.041343077 & 0.783606 & 1.721428019 \\
\hline NM_032878 & ALKBH6 & 0.000488753 & 0.041343077 & 0.779517 & 1.716556482 \\
\hline NM_001005845 & ADAM9 & 0.000490126 & 0.041343077 & -0.60635 & -1.52240188 \\
\hline ВC082977 & unknown & 0.000490245 & 0.041343077 & 1.373963 & 2.591816326 \\
\hline ВС044216 & BAG5 & 0.000491284 & 0.041353283 & -0.40791 & -1.326764266 \\
\hline AK074137 & CCDC95 & 0.000496135 & 0.04168363 & 0.602465 & 1.518308114 \\
\hline NM_001014837 & CUTA & 0.000498128 & 0.041773213 & 0.530065 & 1.443994594 \\
\hline ВC098342 & CSAD & 0.00051218 & 0.0428148 & 0.593121 & 1.508506922 \\
\hline
\end{tabular}


Continued

\begin{tabular}{|c|c|c|c|c|c|}
\hline $\mathrm{AB} 051543$ & SYNE1 & 0.000515072 & 0.0428148 & 1.896385 & 3.722791433 \\
\hline NM_013347 & RPA4 & 0.000515409 & 0.0428148 & 0.847504 & 1.799385386 \\
\hline AK055835 & OSBPL8 & 0.000516434 & 0.0428148 & -0.416 & -1.334226164 \\
\hline NM_032204 & ASCC2 & 0.000517193 & 0.0428148 & 0.414808 & 1.333120959 \\
\hline NM_013961 & NRG1 & 0.000518384 & 0.0428148 & 2.575704 & 5.961618096 \\
\hline NM_003427 & ZNF76 & 0.000519132 & 0.0428148 & 0.721459 & 1.648848457 \\
\hline XM_290777 & ARL16 & 0.00051956 & 0.0428148 & 0.36928 & 1.291708172 \\
\hline $\mathrm{BC} 035152$ & unknown & 0.000519799 & 0.0428148 & 0.718988 & 1.64602749 \\
\hline ВC014165 & GLI4 & 0.000520862 & 0.0428148 & 1.079039 & 2.112628722 \\
\hline NM_005044 & PRKX & 0.000521007 & 0.0428148 & 0.579234 & 1.494055797 \\
\hline NM_145316 & C6orf128 & 0.000522289 & 0.042841971 & 1.728398 & 3.313595802 \\
\hline $\mathrm{BC} 045712$ & GPC1 & 0.00053116 & 0.043463852 & 0.92762 & 1.902135661 \\
\hline NM_022091 & $\mathrm{ASCC} 3$ & 0.000531801 & 0.043463852 & 0.644132 & 1.562799235 \\
\hline $\mathrm{BC} 037283$ & ZMPSTE24 & 0.000536121 & 0.043713469 & -0.58085 & -1.495729639 \\
\hline BC011968 & DECR2 & 0.000536796 & 0.043713469 & 0.958622 & 1.943452159 \\
\hline NM_152619 & DCAMKL2 & 0.00054278 & 0.04405283 & -0.4426 & -1.359048233 \\
\hline ВC067819 & TMEM29 & 0.00054292 & 0.04405283 & 0.626882 & 1.544223621 \\
\hline AK057461 & C22orf25 & 0.000549901 & 0.044539022 & 0.49342 & 1.407778411 \\
\hline NM_181690 & AKT3 & 0.000555888 & 0.044943089 & -0.39999 & -1.319496263 \\
\hline $\mathrm{BC} 036557$ & KIAA1394 & 0.000557531 & 0.044958077 & 1.200662 & 2.298450457 \\
\hline $\mathrm{BC} 011250$ & MTMR1 & 0.00055807 & 0.044958077 & 0.406178 & 1.325170515 \\
\hline ВC071709 & ERH & 0.00056312 & 0.045087179 & -0.2315 & -1.174054907 \\
\hline NM_005176 & ATP5G2 & 0.000564545 & 0.045087179 & 0.633518 & 1.551343512 \\
\hline BC101727 & MCM10 & 0.000567888 & 0.045087179 & -3.05493 & -8.310486809 \\
\hline NM_001013845 & CXorf40B & 0.000568212 & 0.045087179 & 0.435675 & 1.352543365 \\
\hline NM_007108 & TCEB2 & 0.000568367 & 0.045087179 & 0.485256 & 1.39983404 \\
\hline CR607247 & DDOST & 0.000568746 & 0.045087179 & 0.213825 & 1.159759031 \\
\hline NM_017575 & SMG6 & 0.000568925 & 0.045087179 & 0.464246 & 1.37959624 \\
\hline AF172850 & LOC51152 & 0.000569645 & 0.045087179 & 0.689944 & 1.613220628 \\
\hline ВС090039 & C1orf160 & 0.000571448 & 0.045087179 & 0.693795 & 1.617533221 \\
\hline NM_015421 & C16orf51 & 0.000571623 & 0.045087179 & 0.659743 & 1.57980083 \\
\hline XM_292717 & DKFZp779B1634 & 0.000573525 & 0.045087179 & -0.89427 & -1.858667629 \\
\hline NM_152355 & ZNF441 & 0.00057355 & 0.045087179 & 0.884635 & 1.846297236 \\
\hline ВC014428 & MTRF1L & 0.000573717 & 0.045087179 & 0.291276 & 1.223722182 \\
\hline NM_153268 & PLCXD2 & 0.000573916 & 0.045087179 & 1.089582 & 2.128124016 \\
\hline ВC009932 & GLTP & 0.000574691 & 0.045087179 & 0.713061 & 1.639278722 \\
\hline
\end{tabular}




\begin{tabular}{|c|c|c|c|c|c|}
\hline NM_003876 & TMEM11 & 0.000578803 & 0.04532703 & 0.579878 & 1.494722798 \\
\hline ВC021229 & SELI & 0.000579761 & 0.04532703 & -0.41266 & -1.331135809 \\
\hline BC041887 & unknown & 0.00058197 & 0.045342305 & 0.566878 & 1.481314735 \\
\hline AK097425 & ACAD10 & 0.000585666 & 0.045551433 & 0.516721 & 1.430699479 \\
\hline NM_032344 & NUDT22 & 0.000591831 & 0.045806523 & 0.353802 & 1.277923772 \\
\hline NM_006322 & TUBGCP3 & 0.000592095 & 0.045806523 & -0.35559 & -1.27950511 \\
\hline NM_152640 & DCP1B & 0.000592794 & 0.045806523 & 0.772194 & 1.70786523 \\
\hline ВС052993 & FAM53C & 0.000593014 & 0.045806523 & -0.33894 & -1.264823925 \\
\hline NM_178336 & MRPL52 & 0.000595191 & 0.045817509 & 0.518488 & 1.432453574 \\
\hline ВC032466 & NAPRT1 & 0.00059663 & 0.045849872 & 0.929263 & 1.904302534 \\
\hline CR605903 & NSFL1C & 0.000601294 & 0.046129631 & 0.60684 & 1.52291939 \\
\hline NM_014727 & MLL2 & 0.000602344 & 0.046131591 & 0.524873 & 1.438806547 \\
\hline NM_006835 & CYC1 & 0.000605633 & 0.046304705 & -0.42322 & -1.340916298 \\
\hline ВC002697 & PPP1CB & 0.00060952 & 0.046452014 & -0.45464 & -1.370436438 \\
\hline AK023219 & PBXIP1 & 0.000610331 & 0.046452014 & 0.221299 & 1.165783092 \\
\hline XM_929117 & LOC392232 & 0.000610654 & 0.046452014 & -2.12231 & -4.353895338 \\
\hline NM_004259 & RECQL5 & 0.000613323 & 0.046528137 & 0.856715 & 1.810910077 \\
\hline NM_020155 & GPR137 & 0.000617221 & 0.046528137 & 0.615799 & 1.532406487 \\
\hline BC000637 & DHRS7 & 0.000617844 & 0.046528137 & 0.476058 & 1.390938127 \\
\hline AF068181 & BLNK & 0.000619257 & 0.046528137 & 2.422056 & 5.359342771 \\
\hline XM_932091 & CEP78 & 0.000619624 & 0.046528137 & -0.81447 & -1.758649574 \\
\hline NM_004099 & STOM & 0.000619923 & 0.046528137 & 0.884093 & 1.845603629 \\
\hline NM_001618 & PARP1 & 0.000622183 & 0.046528137 & -0.31139 & -1.240902535 \\
\hline NM_017421 & COQ3 & 0.000622434 & 0.046528137 & 0.378414 & 1.299911897 \\
\hline NM_025072 & PTGES2 & 0.000622467 & 0.046528137 & 0.402225 & 1.321544306 \\
\hline NM_000920 & $\mathrm{PC}$ & 0.00062302 & 0.046528137 & 0.562699 & 1.477030351 \\
\hline AK124869 & SH2D5 & 0.000624509 & 0.046562126 & 0.577474 & 1.492234623 \\
\hline NM_053052 & C1orf142 & 0.000626004 & 0.046596443 & 0.512315 & 1.426337189 \\
\hline XM_930966 & LOC642637 & 0.000628024 & 0.046604738 & 0.923966 & 1.897324111 \\
\hline NM_001001551 & C9orf103 & 0.000629529 & 0.046604738 & 0.459762 & 1.375315134 \\
\hline NM_018309 & TBC1D23 & 0.000629772 & 0.046604738 & -0.23405 & -1.17613531 \\
\hline NM_014891 & PDAP1 & 0.000630255 & 0.046604738 & 0.368011 & 1.290572433 \\
\hline NM 001008393 & LOC201725 & 0.000635187 & 0.046892446 & -1.0742 & -2.105558118 \\
\hline
\end{tabular}


Continued

\begin{tabular}{|c|c|c|c|c|c|}
\hline NM_022374 & ARL6IP2 & 0.000637328 & 0.046910385 & -0.41289 & -1.331350194 \\
\hline NM_013362 & ZNF225 & 0.000637514 & 0.046910385 & -0.51455 & -1.428547369 \\
\hline NM_033415 & ARMC6 & 0.000643082 & 0.047187228 & 0.579687 & 1.494525122 \\
\hline NM_001012706 & LOC283551 & 0.000644706 & 0.047187228 & 0.373978 & 1.295921129 \\
\hline XM_930936 & unknown & 0.000645181 & 0.047187228 & -0.24036 & -1.181290415 \\
\hline NM_001005909 & IHPK2 & 0.000645467 & 0.047187228 & 0.751259 & 1.683260629 \\
\hline ВC093739 & AP3B2 & 0.00064894 & 0.047244081 & 1.555147 & 2.93863623 \\
\hline NM_005094 & SLC27A4 & 0.000650072 & 0.047244081 & 0.730493 & 1.659206337 \\
\hline XM_497141 & LOC441511 & 0.000650431 & 0.047244081 & -0.36004 & -1.283461958 \\
\hline NM_000757 & CSF1 & 0.000650441 & 0.047244081 & 0.73629 & 1.665886383 \\
\hline NM_005143 & HP & 0.000653102 & 0.047360936 & 0.690281 & 1.613597539 \\
\hline $\mathrm{BC} 058843$ & ZBTB8OS & 0.000656165 & 0.047365676 & 0.365143 & 1.288008949 \\
\hline NM_006779 & CDC42EP2 & 0.000656681 & 0.047365676 & 1.124931 & 2.180911386 \\
\hline NM_152436 & MGC39497 & 0.000656822 & 0.047365676 & 0.388693 & 1.309206347 \\
\hline AK025630 & RBED1 & 0.000657375 & 0.047365676 & 0.595552 & 1.51105023 \\
\hline ВС052639 & MRPL43 & 0.000660028 & 0.047381968 & 0.387599 & 1.308214787 \\
\hline NM_001029874 & REP15 & 0.000661069 & 0.047381968 & 0.622925 & 1.539993892 \\
\hline NM_014947 & FOXJ3 & 0.000661342 & 0.047381968 & -0.25004 & -1.189241904 \\
\hline NM_001010887 & ASAH3L & 0.000664726 & 0.047381968 & 1.260625 & 2.395994965 \\
\hline ВС070096 & C3orf63 & 0.000665405 & 0.047381968 & -0.49131 & -1.405725312 \\
\hline ВC005338 & CAPZA2 & 0.000665851 & 0.047381968 & -0.32785 & -1.255142019 \\
\hline NM_015997 & C1orf66 & 0.000666251 & 0.047381968 & 0.781647 & 1.719092538 \\
\hline NM_033419 & PERLD1 & 0.000666887 & 0.047381968 & 0.771842 & 1.707448677 \\
\hline NM_020680 & SCYL1 & 0.000667862 & 0.047381968 & 0.335349 & 1.261682792 \\
\hline NM_024945 & C9orf76 & 0.000668122 & 0.047381968 & -0.41692 & -1.335071268 \\
\hline NM_031450 & C11orf68 & 0.000669492 & 0.047404423 & 0.461952 & 1.3774046 \\
\hline $\mathrm{BC} 040516$ & SGIP1 & 0.000671645 & 0.04747299 & 0.782768 & 1.720428854 \\
\hline AK125726 & unknown & 0.000672894 & 0.04747299 & 0.798684 & 1.739513851 \\
\hline ВС020690 & LY96 & 0.000673622 & 0.04747299 & 0.485133 & 1.399715195 \\
\hline NM_020458 & TTC7A & 0.000676521 & 0.047602801 & 0.469612 & 1.384736707 \\
\hline NM_003784 & SERPINB7 & 0.000678755 & 0.047638651 & 1.710382 & 3.272475387 \\
\hline ВС009476 & PELI2 & 0.000679154 & 0.047638651 & -0.74678 & -1.678044859 \\
\hline NM_015481 & ZNF385 & 0.000680205 & 0.047638651 & 0.919989 & 1.8921004 \\
\hline NM_003352 & SUMO1 & 0.000685021 & 0.047764526 & 0.250882 & 1.189934372 \\
\hline NM_004047 & ATP6V0B & 0.000686532 & 0.047764526 & 0.487556 & 1.402067689 \\
\hline ВC019348 & MGC70863 & 0.000686616 & 0.047764526 & 0.765266 & 1.699683847 \\
\hline
\end{tabular}




\begin{tabular}{|c|c|c|c|c|c|}
\hline NM_014223 & NFYC & 0.000686871 & 0.047764526 & 0.605575 & 1.521584716 \\
\hline BC108908 & POLD3 & 0.000687496 & 0.047764526 & -0.69343 & -1.617127755 \\
\hline XM_926355 & LOC642535 & 0.000688366 & 0.047764526 & 0.406239 & 1.325226165 \\
\hline NM_001946 & DUSP6 & 0.00069063 & 0.047847943 & 0.493391 & 1.40775024 \\
\hline NM_001039670 & HOM-TES-103 & 0.000693255 & 0.047888196 & 0.474899 & 1.389820722 \\
\hline BC100018 & COMT & 0.000693338 & 0.047888196 & 0.589414 & 1.504635737 \\
\hline ВC095471 & HRAS & 0.000696156 & 0.047993912 & 1.113787 & 2.164130184 \\
\hline ВC034991 & MNS1 & 0.00069736 & 0.047993912 & -1.18016 & -2.266024111 \\
\hline NM_021078 & GCN5L2 & 0.000699006 & 0.047993912 & 0.622971 & 1.540042935 \\
\hline XM_929378 & LOC646450 & 0.000699132 & 0.047993912 & 1.152244 & 2.22259258 \\
\hline XM_209704 & LOC653314 & 0.000701491 & 0.048082588 & 0.237471 & 1.178924333 \\
\hline XM_376342 & LOC644162 & 0.000704249 & 0.048164703 & -0.5508 & -1.464895509 \\
\hline ВC010991 & RBED1 & 0.000705285 & 0.048164703 & 0.631695 & 1.549383836 \\
\hline NM_199337 & LOC374395 & 0.000705898 & 0.048164703 & 0.661341 & 1.58155216 \\
\hline NM_003086 & SNAPC4 & 0.00070746 & 0.048190421 & 0.643353 & 1.561955105 \\
\hline NM_058191 & C21 orf66 & 0.000708415 & 0.048190421 & -0.37267 & -1.294743262 \\
\hline ВC032947 & MTMR1 & 0.00071187 & 0.048352415 & 0.130105 & 1.09437307 \\
\hline ВC044792 & AMT & 0.000713431 & 0.048385478 & 0.52721 & 1.441139863 \\
\hline AY302071 & APTX & 0.000715257 & 0.048431746 & 0.430191 & 1.347412412 \\
\hline ВC048281 & ZRANB1 & 0.000716389 & 0.048431746 & -0.41267 & -1.331148111 \\
\hline NM_016090 & RBM7 & 0.00071734 & 0.048431746 & -0.51903 & -1.432994148 \\
\hline NM_014145 & C20orf30 & 0.000721735 & 0.048655524 & 0.29365 & 1.225737801 \\
\hline NM_018683 & ZNF313 & 0.000723195 & 0.048681066 & 0.29233 & 1.224616767 \\
\hline NM_012267 & HSPBP1 & 0.000726383 & 0.048822679 & 0.677616 & 1.599494403 \\
\hline XM_932116 & LOC440341 & 0.000729311 & 0.048946475 & -0.37501 & -1.29684773 \\
\hline NM_016581 & ECSIT & 0.000734144 & 0.049112906 & 0.584599 & 1.499621691 \\
\hline NM_006612 & KIF1C & 0.000734279 & 0.049112906 & 0.829564 & 1.777148049 \\
\hline NM_016399 & TRIAP1 & 0.00073561 & 0.049112906 & 0.891867 & 1.855576105 \\
\hline AK094016 & RFNG & 0.000736154 & 0.049112906 & 0.753417 & 1.685780491 \\
\hline BC107682 & NDUFC1 & 0.00074159 & 0.049402399 & 0.818284 & 1.763306806 \\
\hline NM_012151 & F8A1 & 0.000747049 & 0.049620452 & 0.322783 & 1.2507408 \\
\hline NM_004593 & SFRS10 & 0.000747067 & 0.049620452 & -0.45939 & -1.374957093 \\
\hline NM_005469 & ACOT8 & 0.000750134 & 0.049750758 & 0.522806 & 1.436746531 \\
\hline NM 031477 & YPEL3 & 0.000754176 & 0.049945282 & 0.337014 & 1.263139089 \\
\hline
\end{tabular}


Supplemental list 2. Annotation of differentailly expressed genes in cancer-associated fibroblasts.

\begin{tabular}{|c|c|c|c|c|c|c|c|c|c|}
\hline GS & SIZE & SOURCE & ES & NES & $\begin{array}{c}\text { Tag } \\
\%\end{array}$ & $\begin{array}{c}\text { Gene } \\
\%\end{array}$ & Signal & $\begin{array}{c}\text { FDR } \\
(\text { median })\end{array}$ & $\begin{array}{l}\text { glob. } \\
\text { p.val }\end{array}$ \\
\hline $\begin{array}{l}\text { RESPONSE_TO_- } \\
\text { ENDOGENOUS } \\
\text { STIMULUS }\end{array}$ & 85 & $\begin{array}{l}\text { Genes annotated by the GO term GO:0009719. } \\
\text { A change in state or activity of a cell or an } \\
\text { organism (in terms of movement, secretion, } \\
\text { enzyme production, gene expression, etc.) as } \\
\text { a result of an endogenous stimulus. }\end{array}$ & 0.3 & 1.31 & 0.27 & 0.18 & 0.22 & 0.32 & 0.01 \\
\hline $\begin{array}{l}\text { ESTABLISHMENT_AND_- } \\
\text { OR_MAINTENANCE_- } \\
\text { OF_CHROMATIN_- } \\
\text { ARCHITECTURE }\end{array}$ & 27 & $\begin{array}{l}\text { Genes annotated by the GO term GO:0006325. } \\
\text { The specification, formation and maintenance } \\
\text { of the physical structure of eukaryotic chromatin. }\end{array}$ & 0.34 & 1.35 & 0.41 & 0.24 & 0.31 & 0.28 & 0.01 \\
\hline $\begin{array}{l}\text { CELL_PROLIFERATION_ } \\
\text { GO_0008283 }\end{array}$ & 178 & $\begin{array}{l}\text { Genes annotated by the GO term GO:0008283. } \\
\text { The multiplication or reproduction of cells, } \\
\text { resulting in the expansion of a cell population. } \\
\text { Genes annotated by the GO term GO:0051649. }\end{array}$ & 0.37 & 1.33 & 0.17 & 0.11 & 0.15 & 0.32 & 0.01 \\
\hline $\begin{array}{l}\text { ESTABLISHMENT_- } \\
\text { OF_CELLULAR_- } \\
\text { LOCALIZATION }\end{array}$ & 111 & $\begin{array}{l}\text { The directed movement of a substance or } \\
\text { cellular entity, such as a protein complex or } \\
\text { organelle, to a specific location within, or in } \\
\text { the membrane of, a cell. } \\
\text { Genes annotated by the GO term GO:0000226. }\end{array}$ & 0.28 & 1.34 & 0.06 & 0.03 & 0.06 & 0.3 & 0.02 \\
\hline $\begin{array}{l}\text { MICROTUBULE_- } \\
\text { CYTOSKELETON_- } \\
\text { ORGANIZATION_- } \\
\text { AND_BIOGENESIS }\end{array}$ & 16 & $\begin{array}{l}\text { A process that is carried out at the cellular level } \\
\text { which results in the formation, arrangement of } \\
\text { constituent parts, or disassembly of cytoskeletal } \\
\text { structures comprising microtubules and their } \\
\text { associated proteins. }\end{array}$ & 0.71 & 1.36 & 0.31 & 0.02 & 0.31 & 0.26 & 0.03 \\
\hline $\begin{array}{l}\text { NEGATIVE_- } \\
\text { REGULATION_} \\
\text { OF_PROGRAMMED_ } \\
\text { CELL_DEATH }\end{array}$ & 50 & $\begin{array}{l}\text { Genes annotated by the GO term GO:0043069. } \\
\text { Any process that stops, prevents or reduces the } \\
\text { frequency, rate or extent of programmed cell } \\
\text { death, cell death resulting from activation of } \\
\text { endogenous cellular processes. }\end{array}$ & 0.24 & 1.04 & 0.04 & 0 & 0.04 & 0.7 & 0.03 \\
\hline $\begin{array}{l}\text { REGULATION_- } \\
\text { OF_DNA_- } \\
\text { METABOLIC_- } \\
\text { PROCESS }\end{array}$ & 20 & $\begin{array}{l}\text { Genes annotated by the GO term GO:0051052. } \\
\text { Any process that modulates the frequency, rate } \\
\text { or extent of the chemical reactions and pathways } \\
\text { involving DNA. }\end{array}$ & 0.54 & 1.42 & 0.35 & 0.16 & 0.3 & 0.17 & 0.04 \\
\hline $\begin{array}{l}\text { DNA_METABOLIC_ } \\
\text { PROCESS }\end{array}$ & 108 & $\begin{array}{l}\text { Genes annotated by the GO term GO:0006259. } \\
\text { The chemical reactions and pathways involving } \\
\text { DNA, deoxyribonucleic acid, one of the two } \\
\text { main types of nucleic acid, consisting of a long, } \\
\text { unbranched macromolecule formed from one, } \\
\text { or more commonly, two, strands of linked } \\
\text { deoxyribonucleotides. }\end{array}$ & 0.37 & 1.41 & 0.31 & 0.17 & 0.26 & 0.16 & 0.04 \\
\hline $\begin{array}{l}\text { RESPONSE_TO_DNA } \\
\text { DAMAGE_STIMULUS }\end{array}$ & 74 & $\begin{array}{l}\text { Genes annotated by the GO term GO:0006974. } \\
\text { A change in state or activity of a cell or an } \\
\text { organism (in terms of movement, secretion, } \\
\text { enzyme production, gene expression, etc.) as } \\
\text { a result of a stimulus indicating damage to its } \\
\text { DNA from environmental insults or errors } \\
\text { during metabolism. }\end{array}$ & 0.31 & 1.28 & 0.28 & 0.18 & 0.24 & 0.43 & 0.04 \\
\hline $\begin{array}{l}\text { INTERPHASE_- } \\
\text { OF_MITOTIC_- } \\
\text { CELL_CYCLE }\end{array}$ & 30 & $\begin{array}{l}\text { Genes annotated by the GO term GO:0051329. } \\
\text { Progression through interphase, the stage of cell } \\
\text { cycle between successive rounds of mitosis. } \\
\text { Canonically, interphase is the stage of the cell } \\
\text { cycle during which the biochemical and } \\
\text { physiologic functions of the cell are performed } \\
\text { and replication of chromatin occurs. }\end{array}$ & 0.65 & 1.39 & 0.47 & 0.16 & 0.39 & 0.19 & 0.05 \\
\hline
\end{tabular}




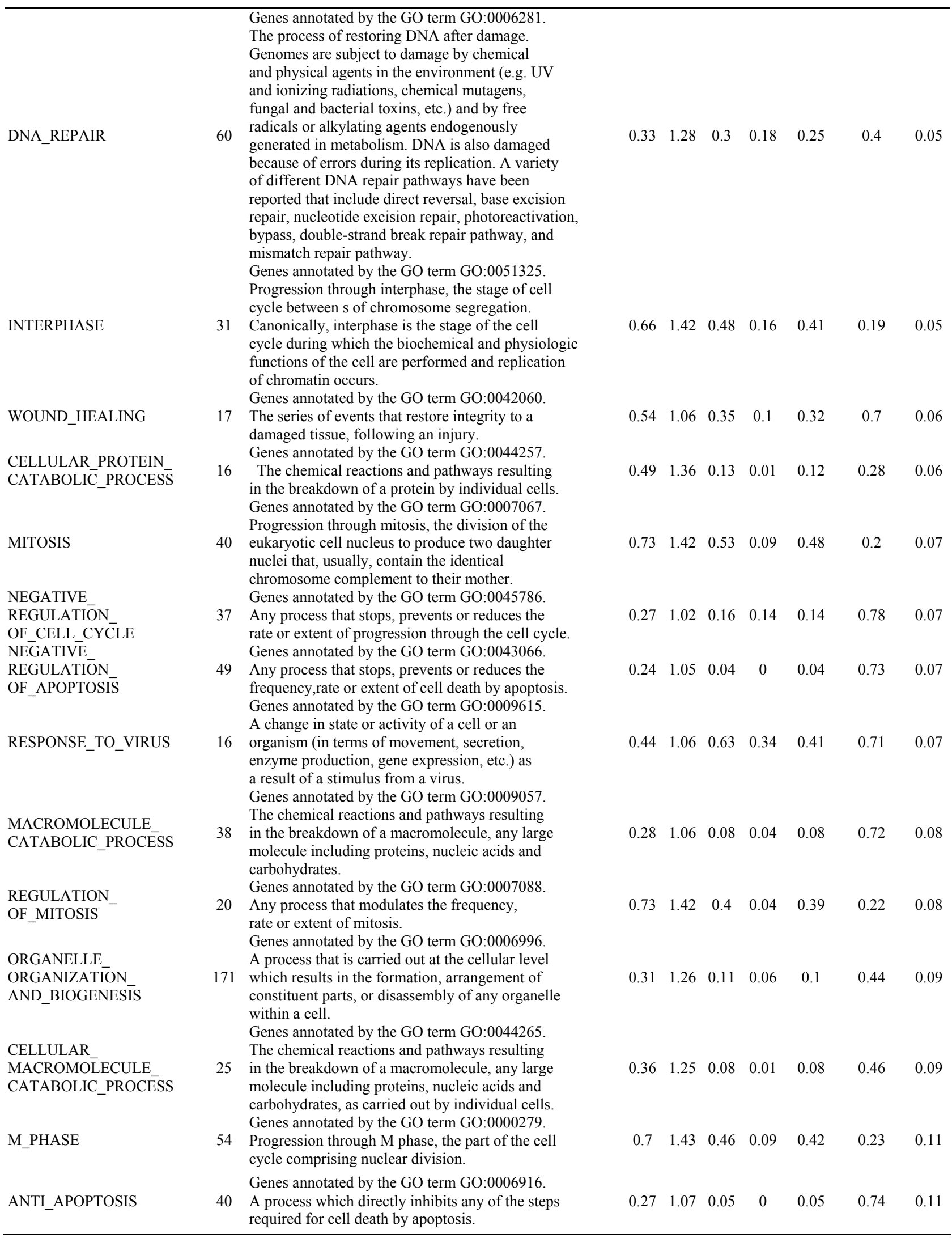


Continued

BIOPOLYMER_-
CATABOLIC_-
PROCESS
REGULATION_OF_-
PHOSPHORYLATION
M_PHASE_OF_MITOTIC__
CELL_CYCLE
NEGA-
TIVE_REGULATION_-
OF_NUCLEOBASE__
NUCLEOSIDE_-__AND_
NUCLEOTIDE_AND_
NUCLEIC_ACID_-
METABOLIC_PROCESS

DNA RECOMBINATION

\author{
CHROMATIN \\ MODIFICATIŌN \\ DNA_REPLICATION \\ HEMOSTASIS \\ NEGA- \\ TIVE_REGULATION_ \\ OF CELLULAR \\ METABOLIC_PR̄OCESS \\ NEGATIVE \\ REGULATIŌN OF \\ METABOLIC_PROCESS
}

UBIQUITIN_CYCLE

\author{
CHROMOSOME \\ ORGANIZATION \\ AND_BIOGENESIS
}

CELL_CYCLE

CHECKPOINT

GO_0000075
Genes annotated by the GO term GO:0043285.

The chemical reactions and pathways resulting

37 in the breakdown of biopolymers, long, repeating

chains of monomers found in nature e.g.

polysaccharides and proteins.

Genes annotated by the GO term GO:0042325.

16 Any process that modulates the frequency, rate

or extent of addition of phosphate groups into

a molecule.

Genes annotated by the GO term GO:0000087.

42 Progression through $\mathrm{M}$ phase, the part of the

mitotic cell cycle during which mitosis takes place.

Genes annotated by the GO term GO:0045934.

Any process that stops, prevents or reduces the

78 frequency, rate or extent of the chemical reactions and pathways involving nucleobases, nucleosides, nucleotides and nucleic acids.

Genes annotated by the GO term GO:0006310.

The processes by which a new genotype is

formed by reassortment of genes resulting in gene combinations different from those that were present in the parents. In eukaryotes genetic

23 recombination can occur by chromosome assortment, intrachromosomal recombination, or nonreciprocal interchromosomal recombination. Intrachromosomal recombination occurs by crossing over. In bacteria it may occur by genetic transformation, conjugation, transduction, or F-duction.

Genes annotated by the GO term GO:0016568.

19 The alteration of DNA or protein in chromatin, which may result in changing the chromatin structure.

$$
\begin{array}{lllllll}
0.29 & 1.06 & 0.08 & 0.04 & 0.08 & 0.73 & 0.11
\end{array}
$$$$
\begin{array}{lllllll}
0.39 & 1.18 & 0.25 & 0.12 & 0.22 & 0.63 & 0.12
\end{array}
$$

$\begin{array}{llllll}0.74 & 1.43 & 0.52 & 0.09 & 0.48 & 0.22\end{array}$

Genes annotated by the GO term GO:0006260.

43 The process whereby new strands of DNA are synthesized. The template for replication can either be an existing DNA molecule or RNA. Genes annotated by the GO term GO:0007599.

17 The stopping of bleeding (loss of body fluid) or the arrest of the circulation to an organ or part. Genes annotated by the GO term GO:0031324. Any process that stops, prevents or reduces the

95 frequency, rate or extent of the chemical reactions and pathways by which individual cells transform chemical substances.

Genes annotated by the GO term GO:0009892. Any process that stops, prevents or reduces the frequency, rate or extent of the chemical reactions and pathways within a cell or an organism.

Genes annotated by the GO term GO:0006512.

15 The cyclical process by which one or more ubiquitin moieties are added to (ubiquitination) and removed from (deubiquitination) a protein. Genes annotated by the GO term GO:0051276. A process that is carried out at the cellular level that results in the formation, arrangement of

43 constituent parts, or disassembly of chromosomes, structures composed of a very long molecule of DNA and associated proteins that carries hereditary information.

Genes annotated by the GO term GO:0000075.

25 A point in the eukaryotic cell cycle where progress through the cycle can be halted until conditions are suitable for the cell to proceed to the next stage. $\begin{array}{lllllll}0.46 & 1.48 & 0.39 & 0.17 & 0.33 & 0.15 & 0.13\end{array}$

$\begin{array}{lllllll}0.27 & 1.02 & 0.37 & 0.23 & 0.28 & 0.8 & 0.13\end{array}$

$\begin{array}{lllllll}0.58 & 1.51 & 0.51 & 0.2 & 0.41 & 0.18 & 0.14\end{array}$

$\begin{array}{lllllll}0.57 & 1.16 & 0.35 & 0.1 & 0.32 & 0.66 & 0.14\end{array}$

$\begin{array}{lllllll}0.23 & 1.09 & 0.12 & 0.1 & 0.11 & 0.75 & 0.14\end{array}$

$\begin{array}{lllllll}0.23 & 1.09 & 0.12 & 0.1 & 0.11 & 0.75 & 0.14\end{array}$

$\begin{array}{lllllll}0.38 & 1.19 & 0.27 & 0.12 & 0.24 & 0.65 & 0.15\end{array}$

$\begin{array}{lllllll}0.52 & 1.46 & 0.44 & 0.24 & 0.34 & 0.21 & 0.15\end{array}$

$\begin{array}{lllllll}0.66 & 1.43 & 0.52 & 0.16 & 0.44 & 0.24 & 0.15\end{array}$ 


\begin{tabular}{|c|c|c|c|c|c|c|c|c|c|}
\hline $\begin{array}{l}\text { REPRODUCTIVE_ } \\
\text { PROCESS }\end{array}$ & 39 & $\begin{array}{l}\text { Genes annotated by the GO term GO:0022414. } \\
\text { A biological process that directly contributes to } \\
\text { the process of producing new individuals by one } \\
\text { or two organisms. The new individuals inherit } \\
\text { some proportion of their genetic material from } \\
\text { the parent or parents. }\end{array}$ & 0.33 & 1.17 & 0.21 & 0.17 & 0.17 & 0.64 & 0.15 \\
\hline $\begin{array}{l}\text { REGULATION_- } \\
\text { OF_PROTEIN_- } \\
\text { MODIFICATION_ } \\
\text { PROCESS }\end{array}$ & 15 & $\begin{array}{l}\text { Genes annotated by the GO term GO: } 0031399 . \\
\text { Any process that modulates the frequency, rate } \\
\text { or extent of the covalent alteration of one } \\
\text { or more amino acid residues within a protein. }\end{array}$ & 0.36 & 1.15 & 0.2 & 0.12 & 0.18 & 0.7 & 0.16 \\
\hline $\begin{array}{l}\text { DNA_DEPENDENT_} \\
\text { DNA_REPLICATION }\end{array}$ & 25 & $\begin{array}{l}\text { Genes annotated by the GO term GO:0006261. } \\
\text { The process whereby new strands of DNA are } \\
\text { synthesized, using parental DNA as a template } \\
\text { for the DNA-dependent DNA polymerases that } \\
\text { synthesize the new strands. }\end{array}$ & 0.62 & 1.49 & 0.48 & 0.17 & 0.4 & 0.17 & 0.16 \\
\hline $\begin{array}{l}\text { NEGATIVE_- } \\
\text { REGULATION_OF_- } \\
\text { DEVELOPMENTAL_- } \\
\text { PROCESS }\end{array}$ & 63 & $\begin{array}{l}\text { Genes annotated by the GO term GO: } 0051093 \text {. } \\
\text { Any process that stops, prevents or reduces the } \\
\text { rate or extent of development, the biological } \\
\text { process whose specific outcome is the progression } \\
\text { of an organism over time from an initial condition } \\
\text { (e.g. a zygote, or a young adult) to a later condition } \\
\text { (e.g. a multicellular animal or an aged adult). }\end{array}$ & 0.23 & 1.08 & 0.16 & 0.16 & 0.13 & 0.78 & 0.16 \\
\hline RESPONSE_TO_STRESS & 182 & $\begin{array}{l}\text { Genes annotated by the GO term GO:0006950. } \\
\text { A change in state or activity of a cell or an } \\
\text { organism (in terms of movement, secretion, } \\
\text { enzyme production, gene expression, etc.) as } \\
\text { a result of a stimulus indicating the organism is } \\
\text { under stress. The stress is usually, but not } \\
\text { necessarily, exogenous (e.g. temperature, } \\
\text { humidity, ionizing radiation). }\end{array}$ & 0.22 & 1.07 & 0.22 & 0.21 & 0.18 & 0.77 & 0.16 \\
\hline $\begin{array}{l}\text { CELL_CYCLE_ARREST_ } \\
\mathrm{GO}_{-} 0007050\end{array}$ & 25 & $\begin{array}{l}\text { Genes annotated by the GO term GO:0007050. } \\
\text { Any process by which progression through the } \\
\text { cell cycle is halted during one of the normal } \\
\text { phases }(\mathrm{G} 1, \mathrm{~S}, \mathrm{G} 2, \mathrm{M}) \text {. }\end{array}$ & 0.28 & 0.99 & 0.16 & 0.14 & 0.14 & 0.81 & 0.17 \\
\hline $\begin{array}{l}\text { NEGA- } \\
\text { TIVE_REGULATION_- } \\
\text { OF_CATALYTIC_ACTIVIT } \\
\text { Y }\end{array}$ & 22 & $\begin{array}{l}\text { Genes annotated by the GO term GO:0043086. } \\
\text { Any process that stops or reduces the activity of } \\
\text { an enzyme. }\end{array}$ & 0.4 & 1.19 & 0.18 & 0.11 & 0.16 & 0.65 & 0.17 \\
\hline $\begin{array}{l}\text { CYTOSKELETON_- } \\
\text { ORGANIZATION_- } \\
\text { AND_BIOGENESIS }\end{array}$ & 70 & $\begin{array}{l}\text { Genes annotated by the GO term GO:0007010. } \\
\text { A process that is carried out at the cellular level } \\
\text { which results in the formation, arrangement of } \\
\text { constituent parts, or disassembly of cytoskeletal } \\
\text { structures. }\end{array}$ & 0.41 & 1.19 & 0.37 & 0.24 & 0.28 & 0.65 & 0.17 \\
\hline $\begin{array}{l}\text { MONOCARBOX- } \\
\text { YLIC_ACID_- } \\
\text { METABOLIC_PROCESS }\end{array}$ & 32 & $\begin{array}{l}\text { Genes annotated by the GO term GO: } 0032787 . \\
\text { The chemical reactions and pathways involving } \\
\text { monocarboxylic acids, any organic acid containing } \\
\text { one carboxyl (COOH) group or anion (COO-). }\end{array}$ & 0.25 & 0.97 & 0.31 & 0.23 & 0.24 & 0.83 & 0.18 \\
\hline FEMALE_PREGNANCY & 15 & $\begin{array}{l}\text { Genes annotated by the GO term GO:0007565. } \\
\text { The physiological processes that allow an embryo } \\
\text { or foetus to develop within the body of a female } \\
\text { animal. It covers the time from fertilization of a } \\
\text { female ovum by a male spermatozoon until birth. }\end{array}$ & 0.3 & 0.99 & 0.27 & 0.17 & 0.22 & 0.82 & 0.18 \\
\hline $\begin{array}{l}\text { REGULATION_OF_ } \\
\text { CELL_CYCLE }\end{array}$ & 89 & $\begin{array}{l}\text { Genes annotated by the GO term GO:0051726. } \\
\text { Any process that modulates the rate or extent of } \\
\text { progression through the cell cycle. }\end{array}$ & 0.47 & 1.51 & 0.33 & 0.17 & 0.27 & 0.17 & 0.19 \\
\hline $\begin{array}{l}\text { NEGA- } \\
\text { TIVE_REGULATION_} \\
\text { OF_BIOLOGICAL_PROCES } \\
\text { S }\end{array}$ & 226 & $\begin{array}{l}\text { Genes annotated by the GO term GO: } 0048519 . \\
\text { Any process that stops, prevents or reduces the } \\
\text { frequency, rate or extent of a biological process. } \\
\text { Biological processes are regulated by many } \\
\text { means; examples include the control of gene } \\
\text { expression, protein modification or interaction } \\
\text { with a protein or substrate molecule. }\end{array}$ & 0.22 & 1.13 & 0.17 & 0.17 & 0.15 & 0.76 & 0.19 \\
\hline $\begin{array}{l}\text { REGULATION_OF_- } \\
\text { CYCLIN_DEPENDENT_ } \\
\text { PROTEIN_KINASE_ } \\
\text { ACTIVITY }\end{array}$ & 25 & $\begin{array}{l}\text { Genes annotated by the GO term GO: } 0000079 \text {. } \\
\text { Any process that modulates the frequency, } \\
\text { rate or extent of CDK activity. }\end{array}$ & 0.32 & 0.99 & 0.16 & 0.07 & 0.15 & 0.83 & 0.2 \\
\hline
\end{tabular}




\begin{tabular}{|c|c|c|c|c|c|c|c|c|c|}
\hline $\begin{array}{l}\text { STRIATED_MUSCLE_ } \\
\text { DEVELOPMENT }\end{array}$ & 20 & $\begin{array}{l}\text { Genes annotated by the GO term GO:0014706. } \\
\text { The process whose specific outcome is the } \\
\text { progression of a striated muscle over time, } \\
\text { from its formation to the mature structure. } \\
\text { Striated muscle contain fibers that are divided } \\
\text { by transverse bands into striations, and cardiac } \\
\text { and skeletal muscle are types of striated muscle. } \\
\text { Skeletal muscle myoblasts fuse to form myotubes } \\
\text { and eventually multinucleated muscle fibers. } \\
\text { The fusion of cardiac cells is very rare } \\
\text { and can only form binucleate cells. }\end{array}$ & 0.35 & 0.97 & 0.2 & 0.15 & 0.17 & 0.84 & 0.22 \\
\hline $\begin{array}{l}\text { GAMETE } \\
\text { GENERATION }\end{array}$ & 30 & $\begin{array}{l}\text { Genes annotated by the GO term GO:0007276. } \\
\text { The generation and maintenance of gametes. } \\
\text { A gamete is a haploid reproductive cell. }\end{array}$ & 0.36 & 1.09 & 0.43 & 0.29 & 0.31 & 0.78 & 0.23 \\
\hline $\begin{array}{l}\text { LOCOMO- } \\
\text { TORY_BEHAVIOR }\end{array}$ & 28 & $\begin{array}{l}\text { Genes annotated by the GO term GO: } 0007626 \text {. } \\
\text { The specific movement from place to place of } \\
\text { an organism in response to external or internal } \\
\text { stimuli. Locomotion of a whole organism in a } \\
\text { manner dependent upon some combination of } \\
\text { that organism's internal state and external } \\
\text { conditions. }\end{array}$ & 0.25 & 0.59 & 0.43 & 0.3 & 0.3 & 0.99 & 0.24 \\
\hline $\begin{array}{l}\text { PRO- } \\
\text { TEIN_MODIFICATION_- } \\
\text { BY_SMALL_PROTEIN_- } \\
\text { CONJUGATION }\end{array}$ & 15 & $\begin{array}{l}\text { Genes annotated by the GO term GO:0032446. } \\
\text { A process by which one or more moieties of a } \\
\text { small protein, such as ubiquitin or a ubiquitin-like } \\
\text { protein, are covalently attached to a target protein. }\end{array}$ & 0.35 & 1.11 & 0.13 & 0.03 & 0.13 & 0.76 & 0.24 \\
\hline CELL_CYCLE_PHASE & 78 & $\begin{array}{l}\text { Genes annotated by the GO term GO:0022403. } \\
\text { A cell cycle process comprising the steps by } \\
\text { which a cell progresses through one of the } \\
\text { biochemical and morphological phases and } \\
\text { events that occur during successive cell } \\
\text { replication or nuclear replication events. }\end{array}$ & 0.67 & 1.52 & 0.54 & 0.16 & 0.46 & 0.22 & 0.25 \\
\hline $\begin{array}{l}\text { FATTY_ACID_- } \\
\text { METABOLIC_PROCESS }\end{array}$ & 20 & $\begin{array}{l}\text { Genes annotated by the GO term GO:0006631. } \\
\text { The chemical reactions and pathways involving } \\
\text { fatty acids, aliphatic monocarboxylic acids } \\
\text { liberated from naturally occurring fats and } \\
\text { oils by hydrolysis. }\end{array}$ & 0.33 & 1.11 & 0.3 & 0.23 & 0.23 & 0.77 & 0.25 \\
\hline CELL_CYCLE_PROCESS & 91 & $\begin{array}{l}\text { Genes annotated by the GO term GO:0022402. } \\
\text { A cellular process that is involved in the } \\
\text { progression of biochemical and morphological } \\
\text { phases and events that occur in a cell during } \\
\text { successive cell replication or nuclear replication } \\
\text { events. }\end{array}$ & 0.68 & 1.55 & 0.54 & 0.16 & 0.46 & 0.18 & 0.25 \\
\hline $\begin{array}{l}\text { NEGATIVE- } \\
\text { REGULATION_- } \\
\text { OF_CELLULAR_- } \\
\text { PROCESS }\end{array}$ & 219 & $\begin{array}{l}\text { Genes annotated by the GO term GO:0048523. } \\
\text { Any process that stops, prevents or reduces the } \\
\text { frequency, rate or extent of cellular processes, } \\
\text { those that are carried out at the cellular level, but } \\
\text { are not necessarily restricted to a single cell. For } \\
\text { example, cell communication occurs among } \\
\text { more than one cell, but occurs at the cellular level. }\end{array}$ & 0.21 & 1.09 & 0.16 & 0.17 & 0.14 & 0.79 & 0.26 \\
\hline $\begin{array}{l}\text { RESPONSE_TO_} \\
\text { CHEMICAL_STIMULUS }\end{array}$ & 108 & $\begin{array}{l}\text { Genes annotated by the GO term GO: } 0042221 . \\
\text { A change in state or activity of a cell or an } \\
\text { organism (in terms of movement, secretion, } \\
\text { enzyme production, gene expression, etc.) as a } \\
\text { result of a chemical stimulus. }\end{array}$ & 0.14 & 0.51 & 0.22 & 0.23 & 0.17 & 0.99 & 0.27 \\
\hline $\begin{array}{l}\text { REGULATION_- } \\
\text { OF_BODY_-_ELS } \\
\text { FLUID_LEVELS }\end{array}$ & 19 & $\begin{array}{l}\text { Genes annotated by the GO term GO:0050878. } \\
\text { Any process that modulates the levels of body } \\
\text { fluids. }\end{array}$ & 0.5 & 1.1 & 0.32 & 0.1 & 0.28 & 0.77 & 0.27 \\
\hline DEFENSE_RESPONSE & 63 & $\begin{array}{l}\text { Genes annotated by the GO term GO: } 0006952 \text {. } \\
\text { Reactions, triggered in response to the presence } \\
\text { of a foreign body or the occurrence of an injury, } \\
\text { which result in restriction of damage to the } \\
\text { organism attacked or prevention/recovery from } \\
\text { the infection caused by the attack. }\end{array}$ & 0.18 & 0.54 & 0.19 & 0.19 & 0.16 & 0.99 & 0.27 \\
\hline
\end{tabular}




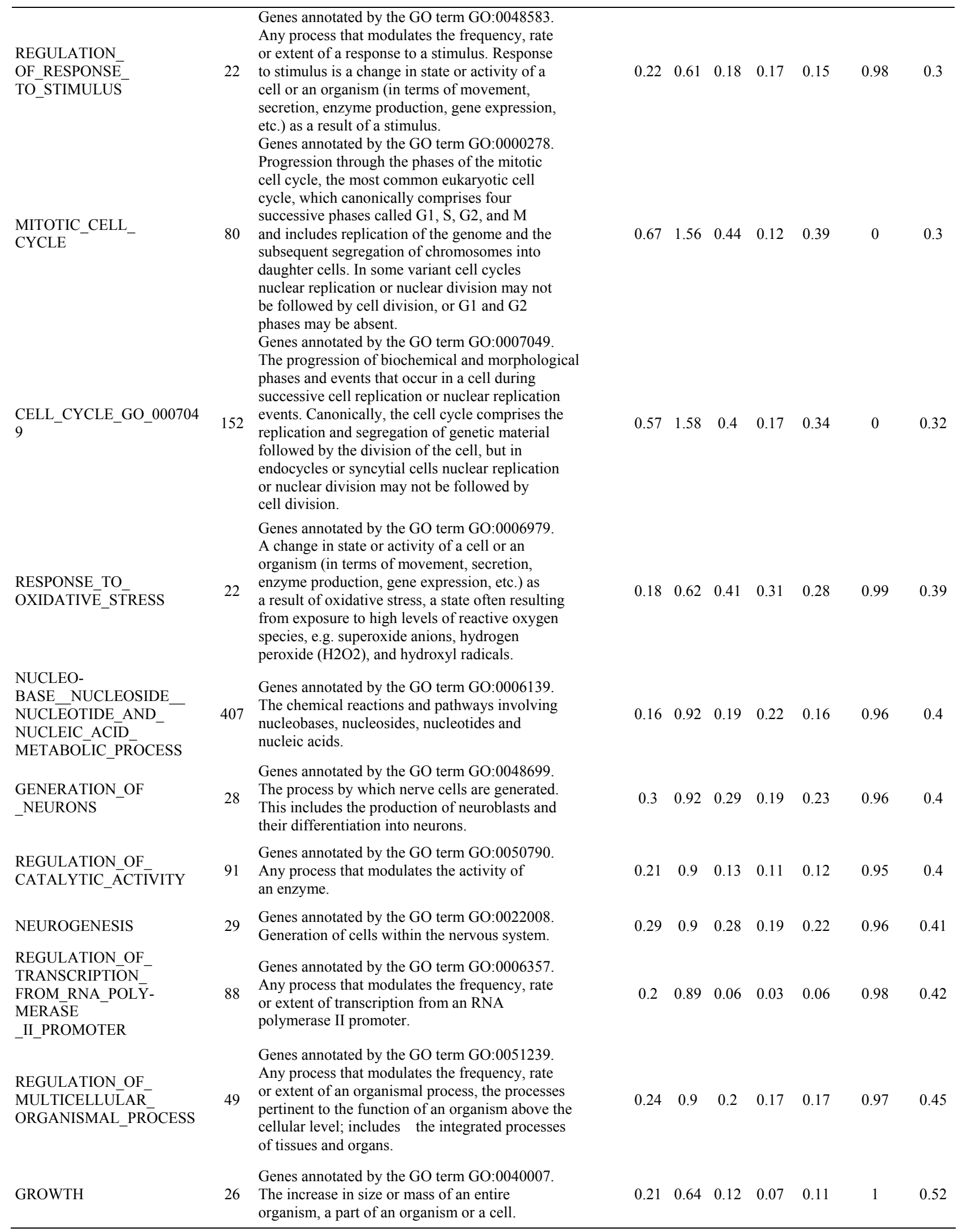




\section{CELL_DEVELOPMENT}

NEGA-

TIVE REGULATION OF TRANSCRIPTION FROM RNA POLYMERAS $\bar{S}$ II PROMOTTER

ACTIN_FILAMENT_ BASED_PROCESS

STRESS_ACTIVATED PROTEIN_KINASE SIGNALING_PATHWAY

POSITIVE_REGULATION OF_CELLULAR_PROCESS

POSITIVE_REGULATION OF_BIOLOGICAL_PROCES $\mathrm{S}$

\author{
REGULATION OF \\ CELLULAR \\ COMPONENT \\ ORGANIZATIŌN \\ AND BIOGENESIS
}

\section{ACTIN_CYTOSKELETON ORGANIZZATION AND_BIOGENESIS}

CELLULAR PROTEIN COMPLEX_ASSEMBLY $\bar{Y}$

REGULATION_OF_

NUCLEOBASE

NUCLEOSIDE

$\bar{N} U C L E O T I D E[\overline{A N D}$

NUCLEIC_ACID_

METABOLIC PROCESS
Genes annotated by the GO term GO:0048468.

The process whose specific outcome is the

188 progression of the cell over time, from its formation to the mature structure. Cell development does not include the steps nvolved in committing a cell to a specific fate.

Genes annotated by the GO term GO:0000122.

31 Any process that stops, prevents or reduces the

frequency, rate or extent of transcription from an RNA polymerase II promoter.

Genes annotated by the GO term GO:0030029. Any cellular process that depends upon or alters

40 the actin cytoskeleton, that part of the cytoskeleton comprising actin filaments and their associated proteins.

Genes annotated by the GO term GO:0031098.

A series of molecular signals in which a stress-activated protein kinase (SAPK) cascade relays one or more of the signals.

Genes annotated by the GO term GO:0048522. Any process that activates or increases the frequency, rate or extent of cellular processes,

224 those that are carried out at the cellular level, but are not necessarily restricted to a single cell. For example, cell communication occurs among more than one cell, but occurs at the cellular level.

Genes annotated by the GO term GO:0048518. Any process that activates or increases the frequency, rate or extent of a biological process.

234 Biological processes are regulated by many means; examples include the control of gene expression, protein modification or interaction with a protein or substrate molecule.

Genes annotated by the GO term GO:0051128. Any process that modulates the frequency, rate or extent of the processes involved in the

37 formation, arrangement of constituent parts, or disassembly of cell structures, including the plasma membrane and any external encapsulating structures such as the cell wall and cell envelope.

Genes annotated by the GO term GO:0030036. A process that is carried out at the cellular level which results in the formation, arrangement of constituent parts, or disassembly of cytoskeletal structures comprising actin filaments and their associated proteins.

Genes annotated by the GO term GO:0043623. The aggregation, arrangement and bonding

15 together of a set of components to form a protein complex, occurring at the level of an individual cell.

Genes annotated by the GO term GO:0019219. Any process that modulates the frequency, rate 206 or extent of the chemical reactions and pathways involving nucleobases, nucleosides, nucleotides and nucleic acids. $\begin{array}{lllllll}0.19 & 0.87 & 0.09 & 0.08 & 0.08 & 1 & 0.54\end{array}$

$\begin{array}{lllllll}0.17 & 0.67 & 0.16 & 0.16 & 0.14 & 1 & 0.54\end{array}$

$\begin{array}{lllllll}0.23 & 0.83 & 0.38 & 0.26 & 0.28 & 1 & 0.54\end{array}$

$\begin{array}{lllllll}0.16 & 0.62 & 0.06 & 0.03 & 0.05 & 1 & 0.57\end{array}$

$\begin{array}{lllllll}0.16 & 0.68 & 0.07 & 0.08 & 0.07 & 1 & 0.58\end{array}$

$\begin{array}{lllllll}0.16 & 0.65 & 0.07 & 0.08 & 0.06 & 1 & 0.58\end{array}$

$\begin{array}{lllllll}0.16 & 0.68 & 0.41 & 0.33 & 0.27 & 1 & 0.59\end{array}$

$\begin{array}{lllllll}0.25 & 0.84 & 0.41 & 0.26 & 0.3 & 1 & 0.59\end{array}$

$\begin{array}{lllllll}0.29 & 0.83 & 0.13 & 0.08 & 0.12 & 1 & 0.59\end{array}$

$\begin{array}{lllllll}0.16 & 0.84 & 0.05 & 0.04 & 0.05 & 1 & 0.59\end{array}$ 


\begin{tabular}{|c|c|c|c|c|c|c|c|c|c|}
\hline $\begin{array}{l}\text { MUSCLE- } \\
\text { DEVELOPMENT }\end{array}$ & 42 & $\begin{array}{l}\text { Genes annotated by the GO term GO:0007517. } \\
\text { The process whose specific outcome is the } \\
\text { progression of the muscle over time, from its } \\
\text { formation to the mature structure. The muscle is } \\
\text { an organ consisting of a tissue made up of } \\
\text { various elongated cells that are specialized to } \\
\text { contract and thus to produce movement and } \\
\text { mechanical work. }\end{array}$ & 0.22 & 0.85 & 0.12 & 0.15 & 0.1 & 1 & 0.6 \\
\hline $\begin{array}{l}\text { REGULATION_OF_- } \\
\text { DEVELOPMENTAL } \\
\text { _PROCESS }\end{array}$ & 150 & $\begin{array}{l}\text { Genes annotated by the GO term GO:0050793. } \\
\text { Any process that modulates the frequency, rate } \\
\text { or extent of development, the biological process } \\
\text { whose specific outcome is the progression of a } \\
\text { multicellular organism over time from an initial } \\
\text { condition (e.g. a zygote, or a young adult) to a } \\
\text { later condition (e.g. a multicellular animal or an } \\
\text { aged adult). }\end{array}$ & 0.19 & 0.82 & 0.07 & 0.08 & 0.07 & 1 & 0.61 \\
\hline $\begin{array}{l}\text { NEGATIVE_- } \\
\text { REGULATION_- } \\
\text { OF_CELL_-_TION } \\
\text { PROLIFERATION }\end{array}$ & 54 & $\begin{array}{l}\text { Genes annotated by the GO term GO:0008285. } \\
\text { Any process that stops, prevents or reduces the } \\
\text { rate or extent of cell proliferation. }\end{array}$ & 0.28 & 0.84 & 0.07 & 0.02 & 0.07 & 1 & 0.61 \\
\hline $\begin{array}{l}\text { REGULATION_OF } \\
\text { HYDROLASE_ACTIVITY }\end{array}$ & 23 & $\begin{array}{l}\text { Genes annotated by the GO term GO:0051336. } \\
\text { Any process that modulates the frequency, rate } \\
\text { or extent of hydrolase activity, the catalysis of the } \\
\text { hydrolysis of various bonds, e.g. C-O, C-N, C-C, } \\
\text { phosphoric anhydride bonds, etc. Hydrolase is the } \\
\text { systematic name for any enzyme of EC class } 3 \text {. } \\
\text { Genes annotated by the GO term GO:0008632. }\end{array}$ & 0.26 & 0.81 & 0.04 & 0 & 0.04 & 1 & 0.62 \\
\hline APOPTOTIC_PROGRAM & 19 & $\begin{array}{l}\text { The intracellular signaling cascade that results } \\
\text { when a cell is triggered to undergo apoptosis. } \\
\text { Genes annotated by the GO term GO:0009888. }\end{array}$ & 0.24 & 0.79 & 0.11 & 0.08 & 0.1 & 1 & 0.64 \\
\hline TISSUE_DEVELOPMENT & 41 & $\begin{array}{l}\text { The process whose specific outcome is the } \\
\text { progression of a tissue over time, from its } \\
\text { formation to the mature structure. } \\
\text { Genes annotated by the GO term GO:0006366. }\end{array}$ & 0.22 & 0.77 & 0.29 & 0.24 & 0.23 & 1 & 0.64 \\
\hline $\begin{array}{l}\text { TRANSCRIPTION_- } \\
\text { FROM_RNA_- } \\
\text { POLYMERASE_II } \\
\text { PROMOTER }\end{array}$ & 135 & $\begin{array}{l}\text { The synthesis of RNA from a DNA template by } \\
\text { RNA polymerase II (Pol II), originating at a } \\
\text { Pol II-specific promoter. Includes transcription of } \\
\text { messenger RNA (mRNA) and certain small nuclear } \\
\text { RNAs (snRNAs). }\end{array}$ & 0.15 & 0.68 & 0.04 & 0.03 & 0.04 & 1 & 0.65 \\
\hline BEHAVIOR & 42 & $\begin{array}{l}\text { Genes annotated by the GO term GO:0007610. } \\
\text { The specific actions or reactions of an organism } \\
\text { in response to external or internal stimuli. } \\
\text { Patterned activity of a whole organism in a } \\
\text { manner dependent upon some combination of } \\
\text { that organism's internal state and external } \\
\text { conditions. }\end{array}$ & 0.26 & 0.7 & 0.31 & 0.24 & 0.24 & 1 & 0.67 \\
\hline $\begin{array}{l}\text { SKELETAL } \\
\text { DEVELOPMENT }\end{array}$ & 39 & $\begin{array}{l}\text { Genes annotated by the GO term GO:0001501. } \\
\text { The process whose specific outcome is the } \\
\text { progression of the skeleton over time, from its } \\
\text { formation to the mature structure. The skeleton } \\
\text { is the bony framework of the body in vertebrates } \\
\text { (endoskeleton) or the hard outer envelope of } \\
\text { insects (exoskeleton or dermoskeleton). }\end{array}$ & 0.22 & 0.78 & 0.15 & 0.15 & 0.13 & 1 & 0.67 \\
\hline $\begin{array}{l}\text { RESPONSE_TO_- } \\
\text { OTHER_ORGANISM }\end{array}$ & 19 & $\begin{array}{l}\text { Genes annotated by the GO term GO:0051707. } \\
\text { A change in state or activity of a cell or an } \\
\text { organism (in terms of movement, secretion, } \\
\text { enzyme production, gene expression, etc.) as } \\
\text { a result of a stimulus from another living organism. }\end{array}$ & 0.27 & 0.71 & 0.32 & 0.24 & 0.24 & 1 & 0.68 \\
\hline SENSORY_PERCEPTION & 45 & $\begin{array}{l}\text { Genes annotated by the GO term GO:0007600. } \\
\text { The series of events required for an organism to } \\
\text { receive a sensory stimulus, convert it to a molecular } \\
\text { signal, and recognize and characterize the signal. }\end{array}$ & 0.19 & 0.73 & 0.16 & 0.14 & 0.14 & 1 & 0.69 \\
\hline $\begin{array}{l}\text { NEGA- } \\
\text { TIVE_REGULATION_- } \\
\text { OF_PROTEIN_METABOLI } \\
\text { C_- } \\
\text { PROCESS }\end{array}$ & 16 & $\begin{array}{l}\text { Genes annotated by the GO term GO:0051248. } \\
\text { Any process that stops, prevents or reduces the } \\
\text { frequency, rate or extent of chemical reactions } \\
\text { and pathways involving a protein. }\end{array}$ & 0.19 & 0.7 & 0.13 & 0.17 & 0.11 & 1 & 0.69 \\
\hline
\end{tabular}




\section{Continued}

NEGA-

TIVE_REGULATION

OF_CELLULAR PROTEIN

$\bar{M}$ MTABOLIC_PROCESS

EMBRYONIC

DEVELOPMENTT

SKELETAL_MUSCLE DEVELOPMENT

\author{
MULTI_ORGANISM \\ PROCESS
}

REGULATION_OF_CELL_ PROLIFERATIŌN
Genes annotated by the GO term GO:0032269.

Any process that stops, prevents or reduces the

15 frequency, rate or extent of the chemical reactions and pathways involving a protein, occurring at the level of an individual cell.

Genes annotated by the GO term GO:0009790.

The process whose specific outcome is the progression of an embryo from its formation until the end of its embryonic life stage. The end of the embryonic stage is organism-specific. For example, for mammals, the process would begin with zygote 26 formation and end with birth. For insects, the process would begin at zygote formation and end with larval hatching. For plant zygotic embryos, this would be from zygote formation to the end of seed dormancy. For plant vegetative embryos, this would be from the initial determination of the cell or group of cells to form an embryo until the point when the embryo becomes independent of the parent plant.

Genes annotated by the GO term GO:0007519. The developmental sequence of events leading to the formation of adult muscle that occurs in the anima. In vertebrate skeletal muscle the main events are: the fusion of myoblasts to form

15 myotubes that increase in size by further fusion to them of myoblasts, the formation of myofibrils within their cytoplasm and the establishment of functional neuromuscular junctions with motor neurons. At this stage they can be regarded as mature muscle fibers.

Genes annotated by the GO term GO:0051704.

42 The processes by which an organism has an effect on another organism of the same or different species.

Genes annotated by the GO term GO:0042127.

106 Any process that modulates the frequency, rate or extent of cell proliferation. $\begin{array}{llllll}0.2 & 0.72 & 0.13 & 0.17 & 0.11 & 1\end{array}$

0.7

$\begin{array}{llllll}0.25 & 0.73 & 0.15 & 0.11 & 0.14 & 1\end{array}$

$\begin{array}{llllll}0.26 & 0.73 & 0.2 & 0.15 & 0.17 & 1\end{array}$

0.75

$\begin{array}{llllll}0.23 & 0.73 & 0.29 & 0.25 & 0.22 & 1\end{array}$

0.75

$\begin{array}{llllll}0.21 & 0.73 & 0.16 & 0.16 & 0.14 & 1\end{array}$

0.76 